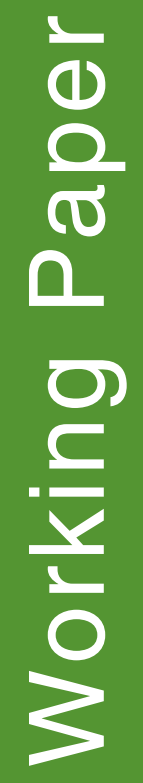

Sandra J. Velarde, Mikkel Kallesoe, Madhushree Sekher and Brent Swallow 


\section{Criteria and indicators for environmental service compensation and reward mechanisms: realistic, voluntary, conditional and pro-poor}

Meine van Noordwijk, Beria Leimona, Lucy Emerton, Thomas P. Tomich, Sandra J. Velarde, Mikkel Kallesoe, Madhushree Sekher and Brent Swallow 


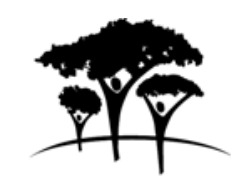

World Agroforestry Centre

TRANSFORMING LIVES AND LANDSCAPES

Correct citation: Van Noordwijk M, Leimona B, Emerton L, Tomich TP, Velarde SJ, Kallesoe M, Sekher M and Swallow B. 2007. Criteria and indicators for environmental service compensation and reward mechanisms: realistic, voluntary, conditional and pro-poor: CES Scoping Study Issue Paper no. 2. ICRAF Working Paper no. 37. Nairobi, Kenya: World Agroforestry Centre.

Titles in the Working Paper Series aim to disseminate interim results on agroforestry research and practices and stimulate feedback from the scientific community. Other publication series from the World Agroforestry Centre include: Agroforestry Perspectives, Technical Manuals and Occasional Papers.

Published by the World Agroforestry Centre

United Nations Avenue

PO Box 30677, GPO 00100

Nairobi, Kenya

Tel: +254(0)20 7224000, via USA +1 6508336645

Fax: +254(0)20 7224001, via USA +1 6508336646

Email: icraf@cgiar.org

Internet: www.worldagroforestry.org

(C) World Agroforestry Centre 2007

ICRAF Working Paper no. 37

The views expressed in this publication are those of the author(s) and not necessarily those of the World Agroforestry Centre and co-publishers.

Articles appearing in this publication may be quoted or reproduced without charge, provided the source is acknowledged. No use of this publication may be made for resale or other commercial purposes.

All images remain the sole property of their source and may not be used for any purpose without written permission of the source.

With generous support of the International Development Research Centre, Canada

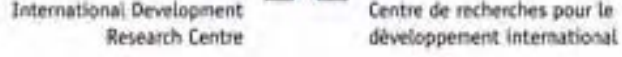


The World Agroforestry Centre (ICRAF) and a diverse team of partners were tasked by the International Development Research Centre (IDRC) to contribute to the conceptualization and development of their Rural Poverty and Environment (RPE) programme related to Compensation and Rewards for Environmental Services (CRES) by providing an overview of relevant developments in Africa, Asia and Latin America, a global synthesis of results and recommendations. Truly global in nature, the CRES Scoping Study was undertaken by the following partners and collaborators based in 7 countries across 4 continents.

The African Centre for Technology Studies (ACTS) is a Nairobi-based science, technology and environment policy Inter-governmental organization (IGO) that generates and disseminates new knowledge through policy analysis and outreach. The Centre's mission is to strengthen the capacity of African countries and institutions to harness science and technology for sustainable development. ACTS strives to rationalize scientific and technological information to enable African countries make effective policy choices for improved living standards. ACTS works with partners and networks including academic and research institutions, national governments, UN bodies, regional and international processes and NGOs. ACTS' research and capacity building activities are organized in five programmatic areas: Biodiversity and Environmental Governance; Energy and Water Security; Agriculture and Food Security; Human Health; and Science and Technology Literacy. Its members are: Kenya, Malawi, Malta, Uganda and Ghana, The World Agroforestry Centre (ICRAF) and the Third World Academy of Sciences (TWAS) are founding members of ACTS.

www.acts.or.ke

Corporación Grupo Randi Randi (CGRR) is a non-profit corporation, whose mission is to build and motivate equitable development and a healthy environment, stimulating the imagination, creativity and the talent of our collaborators, incorporating gender, generation and ethnic equality, local participation, the sustainable management of natural resources and the conservation of biodiversity. CGRR was legalized in Ecuador in 2000, currently has 17 members, and operates a range of research and development projects, with international and national funding, ranging from participatory watershed management, watershed inventories and modeling, gender and environment, community conservation, conservation planning for protected areas and integrated crop management for sustainable development. CGRR is a member of the Consorcio para el Desarrollo Sostenible en los Andes (CONDESAN), the International Union for the Conservation of Nature (IUCN), the Ecuadorian association of environmental NGOs, (CEDENMA), and is a founding member of RISAS, a national network focused on the study and promotion of environmental services research and action. www.randirandi.org

Forest Trends is an international non-profit organization that works to expand the value of forests to society; to promote sustainable forest management and conservation by creating and capturing market values for ecosystem services; to support innovative projects and companies that are developing these new markets; and to enhance the livelihoods of local communities living in and around those forests. We analyze strategic market and policy issues, catalyze connections between forward-looking producers, communities and investors, and develop new financial tools to help markets work for conservation and people.

www.forest-trends.org

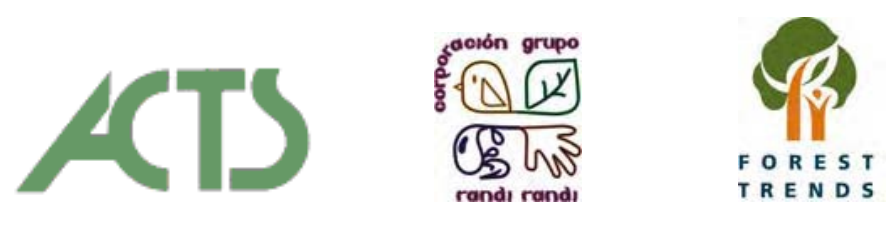


The Institute for Social and Economic Change (ISEC) is an all India Institute for Interdisciplinary Research and Training in the Social Sciences, established in 1972 by the late Professor VKRV Rao. It is registered as a Society under the Karnataka Societies Registration Act, 1960, to create a blend of fieldoriented empirical research and advances in social science theories leading to better public policy formulation. Its mission is to conduct interdisciplinary research in analytical and applied areas of social sciences, encompassing diverse aspects of development; to assist both central and state governments by undertaking systematic studies of resource potential, identifying factors influencing growth and examining measures for reducing poverty; and to establish fruitful contacts with other institutions and scholars engaged in social science research through collaborative research programmes and seminars, and to conduct training courses and refresher programmes for university and college teachers and public functionaries.

www.isec.ac.in

The World Conservation Union (IUCN): Founded in 1948, IUCN brings together States, Government agencies and a diverse range of NGOs in a unique partnership with over 1000 members spread across some 150 countries. As a Union IUCN seeks to influence, encourage and assist societies throughout the world to conserve the integrity and diversity of nature and to ensure that any use of natural resources is equitable and ecologically sustainable.

www.iucn.org

The United Nations Environment Programme (UNEP) is the voice for the environment in the United Nations system. It is an advocate, educator, catalyst and facilitator, promoting the wise use of the planet's natural assets for sustainable development. UNEP's mission is "to provide leadership and encourage partnership in caring for the environment by inspiring, informing, and enabling nations and peoples to improve their quality of life without compromising that of future generations".

www.unep.org

The World Agroforestry Centre (ICRAF) is the international leader in the science and practice of integrating 'working trees' on small farms and in rural landscapes. We have invigorated the ancient practice of growing trees on farms, using innovative science for development to transform lives and landscapes. The World Agroforestry Centre is one of the 15 centres supported by the Consultative Group on International Agricultural Research (CGIAR).

http://www.worldagroforestry.org
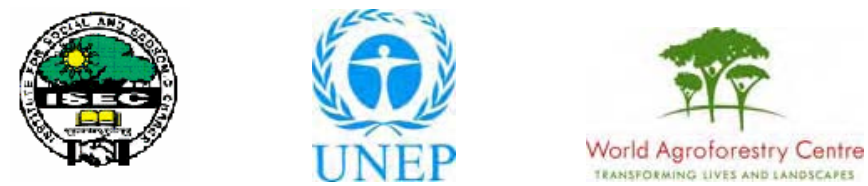


\section{About the authors}

Meine van Noordwijk Regional Coordinator, Southeast Asia Programme, World Agroforestry Centre (ICRAF), Bogor, Indonesia. Contact: m.van-noordwijk@cgiar.org

Beria Leimona

Lucy Emerton

Thomas P. Tomich

Sandra J. Velarde

Mikkel Kallesoe

Madhushree Sekher

Brent Swallow
Research Officer, RUPES Programme. World Agroforestry Centre (ICRAF), Bogor, Indonesia

World Conservation Union (IUCN), Colombo (Sri Lanka)

World Agroforestry Centre (ICRAF) Nairobi, Kenya.

Programme Associate, ASB - Partnership for the Tropical Forest Margins, Nairobi, Kenya

Senior Programme Officer, Asia Regional Environmental Economics Programme, World Conservation Union (IUCN), Colombo, Sri Lanka.

Associate Faculty, Centre for Ecological Economics \& Natural Resources Institute for Social and Economic Change.

Principal Scientist and Theme Leader for Environmental Services, World Agroforestry Centre (ICRAF) Nairobi, Kenya. Overall Coordinator of the CES Global Scoping Study.

\section{Acknowledgements}

The ideas presented here have gradually matured in discussions with many of the participants to the Regional Workshops and (co)authors of other issue papers. We gratefully acknowledge their interest and discussion. Ideas have also benefited from many colleagues in the RUPES network - too many to be named individually. We also acknowledge the generous financial and intellectual support of IDRC, particularly Dr. Hein Mallee 


\begin{abstract}
Working markets are by definition realistic, voluntary and conditional. Their effects on poverty and human well-being are mixed. Many environmental problems and the increasing scarcity of ecosystem services are linked to 'market failures'. Time lags, complex cause-effect linkages, and multiple layers of rights and responsibilities, make many environmental 'service' considerations externalities of decision-making processes focussed on 'marketable goods'. Which combination of characteristics is needed for mechanisms that internalize the costs and benefits of ecosystem utilization enough to avoid environmental degradation beyond thresholds of sustainability? Can market-based mechanisms be pro-poor? We set out to identify mutually - beneficial opportunities for the 'modifiers' and 'beneficiaries' of environmental services to develop agreements and contracts as an alternative to a purely regulatory approach to environmental management. We do not ignore regulation, but rather see regulations as defining the domain for voluntary and conditional rewards for environmental services (ES). Inputs into the analysis are derived from theory and emerging practice in action research sites and pilot application schemes. Theoretical insights are drawn from social welfare theory (development and environmental economics and project appraisal), institutional economics (principal agent problems, game theory) and integrated natural resource management. We present a general framework to clarify the multiple pathways between poverty and mechanisms for compensation and reward for environmental services (8 identified so far) and a set of criteria and indicators for evaluating those mechanisms. Two main classes and six main criteria are formulated. The first class relates to the effectiveness, efficiency and sustainability of compensation and reward for environmental services (CRES) institutions, with environmental services as the primary target. The criteria in this class relate to three questions that predominate in the scoping, stakeholder analysis and negotiation, and implementation stages of establishing a compensation and reward mechanism, respectively: Will rewards be realistic? Will they be voluntary? What conditionality will apply? The second class of three questions is aimed at the equity dimension. Is poverty linked to environmental services? Who is/will be excluded from the mechanism? Are the rewards 'pro-poor'? A total of 12 sub-criteria with a range of possible indicators are proposed under the overall headings of realistic, conditional, voluntary and pro-poor. The paper also presents hypotheses about the way that various stakeholders will perceive and negotiate assessment criteria in particular circumstances. The paper concludes with a discussion of the possibility of a middle ground for negotiating voluntary reward mechanisms that are site-specific and yet have affordable transaction costs.
\end{abstract}

\title{
Keywords
}

Environmental services, ecosystem services, payment for environmental services, compensation and rewards for environmental services, human well-being 


\section{Preface}

From the beginning of 2006 until March 2007, the World Agroforestry Centre (ICRAF) led a consortium of organizations and individuals from around the world in a pan-tropical scoping study of Compensation and Rewards for Environmental Services (CRES). The scoping study was commissioned by the Rural Poverty and Environment Programme of the International Development Research Centre of Canada (IDRC) to identify critical issues affecting the development, operation, impacts and institutionalization of mechanisms linking beneficiaries of ecosystem services with stewards of those ecosystems. Particular attention is paid to the potential for CRES to alleviate or exacerbate the multiple dimensions of poverty: rights to productive assets, streams of income and consumption, and vulnerability to shocks.

The scoping study included a series of regional workshops held in Latin America (Quito, Ecuador), Asia (Bangalore, India) and Africa (Nairobi, Kenya). Participants presented and discussed practical CRES experiences from across the developing world, experiences which informed and challenged the development of several cross-cutting issue papers. A series of nine working papers have been prepared to summarize the results of the scoping study, including an introductory paper, three regional workshop reports, and five issue papers on key topics.

ICRAF Working paper 32 - Compensation and Rewards for Environmental Services in the Developing World: Framing Pan-Tropical Analysis and Comparison.

ICRAF Working paper 33 - Report on the Latin American Regional Workshop on Compensation for Environmental Services and Poverty Alleviation in Latin America.

ICRAF Working paper 34 - Asia Regional Workshop on Compensation for Ecosystems Services. A component of the global scoping study on compensation for ecosystem services.

ICRAF Working paper 35 - African Regional Workshop on Compensation for Ecosystem Services (CES).

ICRAF Working paper 36 - Exploring the inter-linkages among and between Compensation and Rewards for Ecosystem Services (CRES) and human well-being: CES Scoping Study Issue Paper no. 1.

ICRAF Working paper 37 - Criteria and indicators for environmental service compensation and reward mechanisms: realistic, voluntary, conditional and pro-poor: CES Scoping Study Issue Paper no. 2.

ICRAF Working paper 38 - The conditions for effective mechanisms of Compensation and Reward for Environmental Services (CRES): CES Scoping Study Issue Paper no. 3.

ICRAF Working paper 39 - Organization and governance for fostering pro-poor Compensation for Environmental Services: CES Scoping Study Issue Paper no. 4.

ICRAF Working paper 40 - How important will different types of Compensation and Reward Mechanisms be in shaping poverty \& ecosystem services across Africa, Asia \& Latin America over the next two decades? CES Scoping Study Issue Paper no. 5.

The working papers are designed for relatively limited circulation of preliminary material. We anticipate that all of the papers will be revised and published in a formal outlet within the next year.

Brent Swallow

World Agroforestry Centre

Nairobi, Kenya
Hein Mallee

International Development Research Centre

Singapore 


\section{Contents}

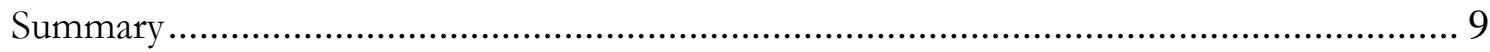

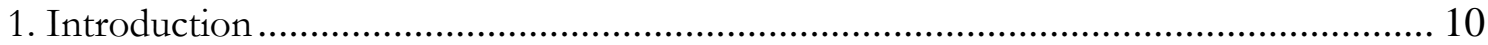

1.1. This review as part of a series of 'issue papers' ............................................... 10

1.2. Regulation, compensation and reward in environmental issue cycles ................ 11

1.3. Poverty dimensions and CRES institutions ................................................... 14

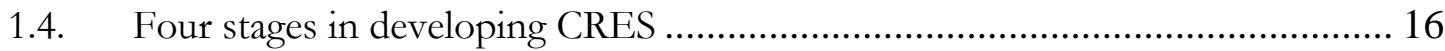

2. Rewards for Environmental Services: stakeholders, stages and agreements .............. 17

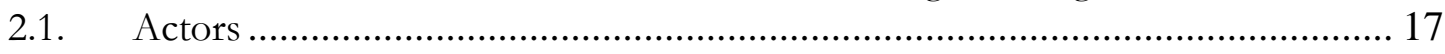

2.2. ES-modifiers, guardians and stewards as potential sellers .............................. 17

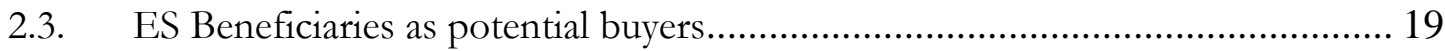

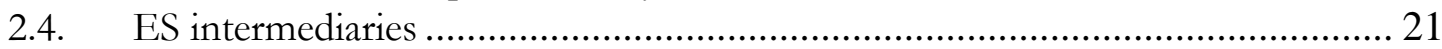

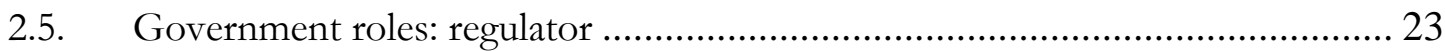

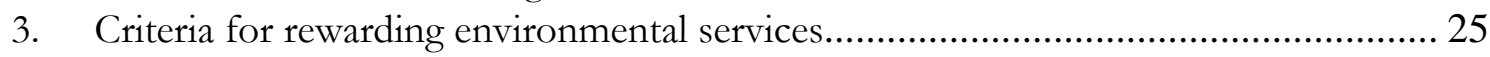

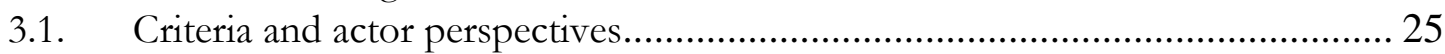

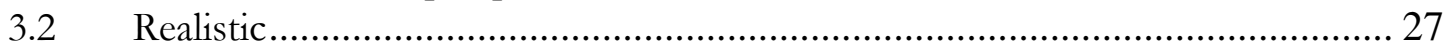

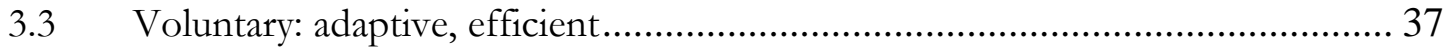

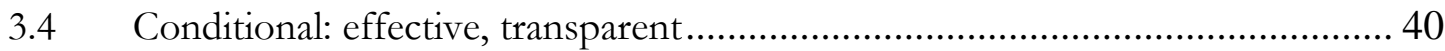

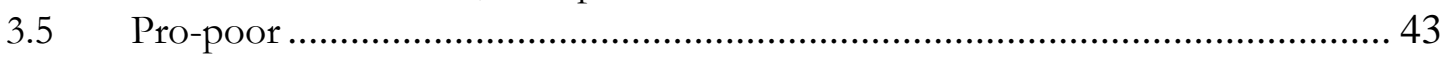

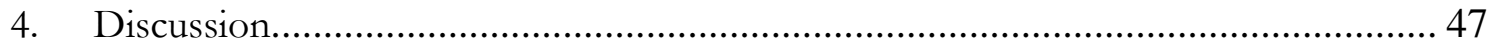

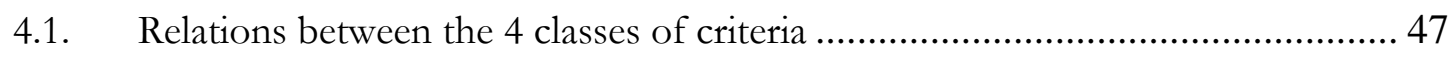

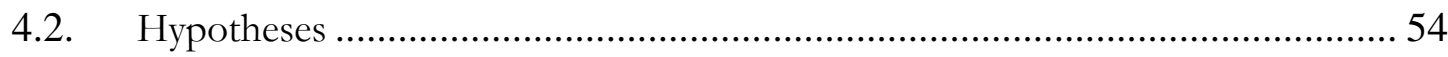

4.3. Conclusions and recommendations to IDRC …........................................... 56

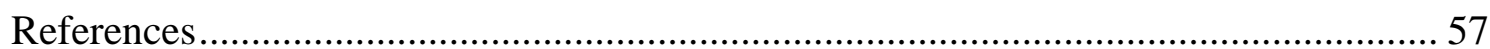




\section{Summary}

Four dimensions and 12 sub-criteria are proposed for effective, efficient, sustainable as well as equitable compensation and reward mechanisms for environmental services.

\begin{tabular}{|c|c|c|c|}
\hline & Stage & Criteria & Sub-criteria \\
\hline \multicolumn{4}{|c|}{ A. Effectiveness, Efficiency and Sustainability } \\
\hline \multirow[t]{4}{*}{$\begin{array}{l}\text { I. } \\
\text { Realistic }\end{array}$} & \multirow[t]{4}{*}{ Scoping } & \multirow{4}{*}{$\begin{array}{l}\text { Effectively mi- } \\
\text { tigates, reduces } \\
\text { or avoids } \\
\text { threats to ES } \\
\text { for all parties } \\
\text { involved }\end{array}$} & $\begin{array}{l}\text { 1. A broadly shared perception of cause-effect } \\
\text { relations links threats to ES or to the ecosystem } \\
\text { that provides ES, to potential activities to } \\
\text { reduce or avoid these threats by identifiable } \\
\text { actors at a relevant temporal and spatial scale }\end{array}$ \\
\hline & & & $\begin{array}{l}\text { 2. The value to ES-beneficiaries of reduction or } \\
\text { avoidance of the threats, relative to alternative } \\
\text { ways to meet their needs, is substantive (within } \\
\text { the context of the key actors) }\end{array}$ \\
\hline & & & $\begin{array}{l}\text { 3. There are opportunity costs and/or } \\
\text { resource access constraints for the potential } \\
\text { 'ES providers' that can be off-set or overcome } \\
\text { without major negative 'external effects' } \\
\text { (leakage) }\end{array}$ \\
\hline & & & $\begin{array}{l}\text { 4. The threat to the ES and its reduction (or } \\
\text { avoidance) by ES providers can be assessed } \\
\text { and monitored in a transparent way, as a basis } \\
\text { for conditional incentives }\end{array}$ \\
\hline \multirow[t]{3}{*}{$\begin{array}{l}\text { II. } \\
\text { Voluntary }\end{array}$} & \multirow[t]{3}{*}{$\begin{array}{l}\text { Stake-holder } \\
\text { analysis }\end{array}$} & \multirow{3}{*}{$\begin{array}{l}\text { Engagement in- } \\
\text { volves choice } \\
\text { rather than } \\
\text { being the object } \\
\text { of regulation }\end{array}$} & $\begin{array}{l}\text { 5. Legitimacy at individual level: representation } \\
\text { is subject to checks and balances }\end{array}$ \\
\hline & & & $\begin{array}{l}\text { 6. Effective voice of all stakeholders is heard; } \\
\text { free and prior informed consent principles } \\
\text { apply }\end{array}$ \\
\hline & & & $\begin{array}{l}\text { 7. Adaptiveness of the mechanism includes a } \\
\text { time frame for review and exit strategy }\end{array}$ \\
\hline \multirow[t]{3}{*}{$\begin{array}{l}\text { III. } \\
\text { Conditional }\end{array}$} & \multirow[t]{3}{*}{$\begin{array}{l}\text { Negotiation } \\
\& \\
\text { implementa- } \\
\text { tion }\end{array}$} & \multirow[t]{3}{*}{$\begin{array}{l}\text { Service and re- } \\
\text { wards or com- } \\
\text { pensation are } \\
\text { dynamically } \\
\text { linked }\end{array}$} & $\begin{array}{l}\text { 8. ES-reward agreements strike a balance } \\
\text { between } \text { outcome-based rewards, targets for } \\
\text { agro-ecosystem conditions, activity-centered } \\
\text { incentives, support for community-scale } \\
\text { resource management and establishment of } \\
\text { trust }\end{array}$ \\
\hline & & & $\begin{array}{l}\text { 9. Sanctions exist to deal with non-compliance } \\
\text { by contract partners, within the human and legal } \\
\text { rights of both sides (linked to exit strategy in } 7 \text { ) }\end{array}$ \\
\hline & & & $\begin{array}{l}\text { 10. ES reward agreements acknowledge the } \\
\text { potential of environmental variability and } \\
\text { change, 'third-party roles' (incl. climate change) } \\
\text { to affect the ecosystem and its ES provision }\end{array}$ \\
\hline
\end{tabular}

\begin{tabular}{|c|c|c|c|}
\hline \multirow[t]{2}{*}{$\begin{array}{l}\text { IV. } \\
\text { Pro-poor }\end{array}$} & \multirow[t]{2}{*}{ All stages } & \multirow{2}{*}{$\begin{array}{l}\text { Mechanisms se- } \\
\text { lected are } \\
\text { positively biased } \\
\text { towards dis- } \\
\text { advantaged } \\
\text { stakeholders }\end{array}$} & $\begin{array}{l}\text { 11. ES reward mechanisms support 'sustainable } \\
\text { development' pathways out of poverty for } \\
\text { achieving Millennium Development Goals, by } \\
\text { addressing the priorities (and criteria...) of 'poor' } \\
\text { stakeholders }\end{array}$ \\
\hline & & & $\begin{array}{l}\text { 12. ES reward mechanisms reduce asset insecurity } \\
\text { (including access to land) }\end{array}$ \\
\hline
\end{tabular}




\section{Introduction}

\subsection{This review as part of a series of 'issue papers'}

This paper presents a review of criteria and indicators that can be used to distinguish between different types of 'reward' and 'compensation' schemes for environmental services and to evaluate their effectiveness, efficiency, sustainability and impacts on equity and poverty reduction. The paper is part of a broader effort to assess current concepts and knowledge about compensation and rewards for environmental services, framing hypotheses and identifying research opportunities that may help advance the effective application of compensation and rewards for environmental services in the developing world.

At the intersection of the global agendas for the end of poverty (Sachs 2005) and the sustainability of environmental services (Millennium Ecosystem Assessment 2005), there are examples of good practice in forest management (Durst et al. 2005) and eco-agriculture (McNeeley and Scherr 2003). Overall, however, tradeoffs between these objectives still dominate (Lee and Barret 2001). The first paper in this series (ICRAF Working Paper no. 32) set out a conceptual framework of compensation and reward schemes, recognizing a number of 'prototypes' of situations where the interaction between the beneficiaries/buyers and modifiers/sellers of environmental services can lead to operational reward schemes. The paper by Kallesoe et al. (this series - ICRAF Working Paper no.36) shows how a multidimensional concept of poverty relates to the multifaceted issues of environmental degradation, ecological and environmental services.

The Millennium Ecosystem Assessment (2004) has popularized the concept of ecosystem services, but concluded that the ecological production functions for these services are poorly quantified and the tradeoffs between economically-valued 'goods' and ecological 'services' cannot yet be reliably assessed (Carpenter et al. 2006). Yet, at the global scale the total draw on ecosystem services for the provision of food, fuelwood, forest fibre and sequestration of $\mathrm{CO}_{2}$ released from fossil fuel in excess of oceanic absorption, has been measured using the concept of the ecological footprint (Rees 1992, 2002). It is at the lower scales and where the interactions between components of the footprint play a role that the ecological production functions are less clear.

Following the Millennium Ecosystem Assessment, we define 'ecosystem services' as the combination of 'provisioning services' (goods, which make up the first three components of the ecological footprint listed above) and environmental services ('regulating + cultural + supportive' services, including the last component of the ecological footprint). In this paper we use ES as shorthand for environmental services. The 'externality' argument applies to 'environmental services' rather than to the 'provisioning' part of the broader concept of ecological services.

Standard economic theory suggests that markets are appropriate institutions for achieving effective and efficient outcomes for the 'tradable goods' part of ecological services, but that the time lags involved, the complex cause-effect relationships, incomplete and contested property rights lead to 'market failure' for most if not all of the 'environmental services' (Tomich et al. 2004a). These environmental services tend to remain externalities in the private decision making process and usually involve 'lateral flows' that affect areas beyond the 'farm' scale (van Noordwijk et al., 2004). Market failure thus constrains the emergence of spontaneous sustainable and equitable solutions for land-use decisions and suggests that additional institutions will be needed. The expectation that 'markets' for environmental services will provide solutions as such seems to ignore the underlying reasons for market failure. However, there is at least some potential for strengthening processes of voluntary engagement and adaptive learning with the outcome-based conditionality that markets provide, to achieve greater efficiency, effectiveness and sustainability (Wunder 2005; 2006). Equity is a real concern of greater outcome-based conditionality, as control over ES tends to be linked to control over land and thus inversely related to at least one dimension of poverty. 
Exclusion from access to land is an important part of reducing threats to ES; this will worsen poverty unless those excluded have other options. Many ES reward mechanisms may therefore be expected to reduce equity - unless specific criteria are met. Expecting 'pro-poor' environmental service reward mechanisms to easily emerge seems to be unrealistic and requires further analysis.

In this paper we will start with an institutional change perspective on the way that environmental issues gain in (local) political importance and can be resolved by a combination of regulation and rewards ('sticks and carrots'). We then consider the roles of various groups of stakeholders in location-specific versions of a reward agreement and discuss the main criteria that can help us to distinguish between different classes of reward mechanisms. These criteria are related to various stakeholder perspectives and examples will be given of how more specific sub-criteria can be linked to indicators of performance. The paper concludes with a list of recommendations for increased donor investment in CRES, with particular focus on knowledge gaps and research needs. Later papers in the series will review the performance of existing schemes with respect to effectiveness, poverty impacts, and the role of intermediaries. The final paper will consider longer term trends in the international arena and differences between continents and countries.

\subsection{Regulation, compensation and reward in environmental issue cycles}

Concerns over 'environmental services' or the 'condition of the global or local ecosystem' come and go. They disappear from the public radar screen when they are either reframed or solved by effective institutions. They usually start with 'externalities' or consequences of land use decisions that negatively affect stakeholders other than the primary decision makers. The issue cycle' (Figure 1A) describes a sequence of stages that can be recognized in the political process of identifying (and challenging...) an 'issue', establishing clarity on the cause-effect relationships, spatial extent and 'size' of the problem and 'attribution of blame', in the 'scoping' stage. If the issue gains political prominence by an increase in the number of people who are concerned, and especially if a coalition emerges with people and institutions with strong political clout, a further stakeholder analysis will focus on what can be done to stop or undo the 'root causes', mitigate the impacts, or adapt to the less desirable condition, as well as an analysis of who benefits from the behaviour that contributes to the causation of the problem.

A

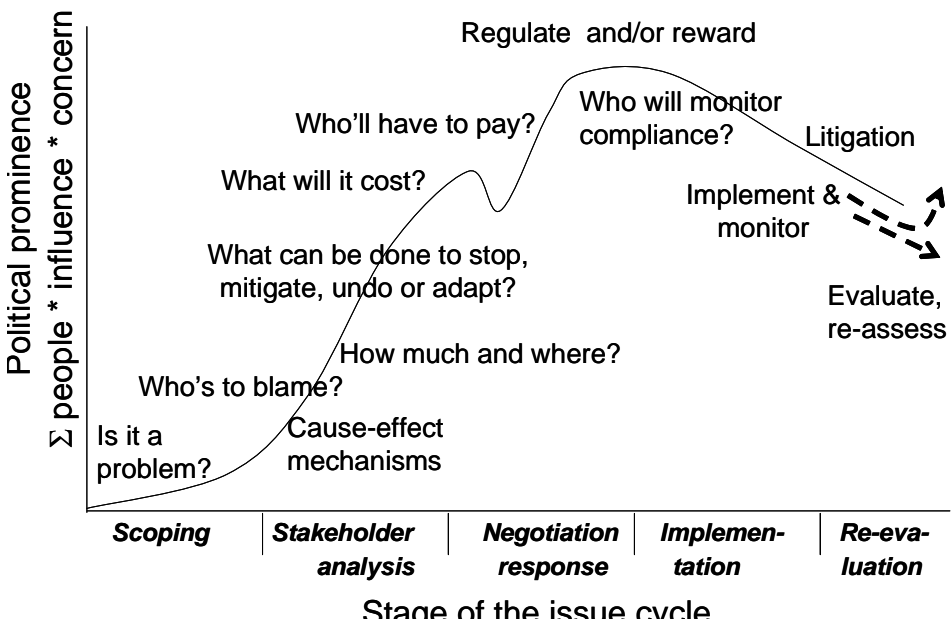

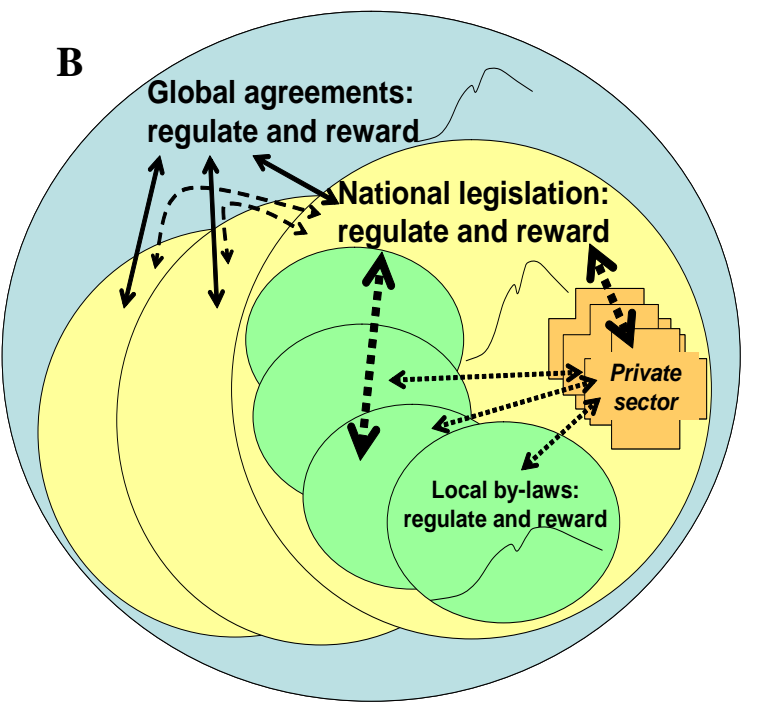

Figure 1 A. Issue cycle or stages in the political process from problem identification to solution; $\mathbf{B}$. Cross-scale linkage of the 'solutions' based on regulation and/or reward of environmental service issues (modified from Tomich et al. 2004b) 
The political discussion then has a number of options: 1) to 'regulate' the behaviour that leads to the problem - setting new standards of what is considered to be acceptable, with possible 'compensation', during a transition period, for the stakeholders who are affected by the regulation, 2) to provide an incentive scheme to 'reward' behaviour that will have positive influence the condition of the system, or 3) to stimulate stakeholders to seek solutions within pre-existing standards. The choice between these three options will depend on the political weight of the various actors and the ability of stakeholders to reduce negative effects on their interests ('right to pollute' versus 'right to live in a pollution-free world'). Once new institutions (either regulatory or based on positive incentives) are in place, a phase of implementation and monitoring ensues, with a need for periodic evaluation and reassessment. As many environmental issues are linked across social-spatial scales (from local to national/regional and global), the institutional solutions will also have to be cross-linked (Figure 1B). Regulations at one level serve as boundaries to what can be 'voluntarily' achieved at another scale.

The relationship between regulation and voluntary, incentive-based mechanisms can be visualized as a 'traffic light' (Figure 2, further developed in Swallow et al, ICRAF Working Paper no. 32), with the transition between red and amber light zone determined by the minimum acceptable behaviour set by regulations and the transition between amber and green determined by the baseline of 'business as usual'. If there is no 'amber' zone (i.e. if the business as usual is in fact operating in the red zone, society cannot expect incentive-based mechanisms to provide solutions).

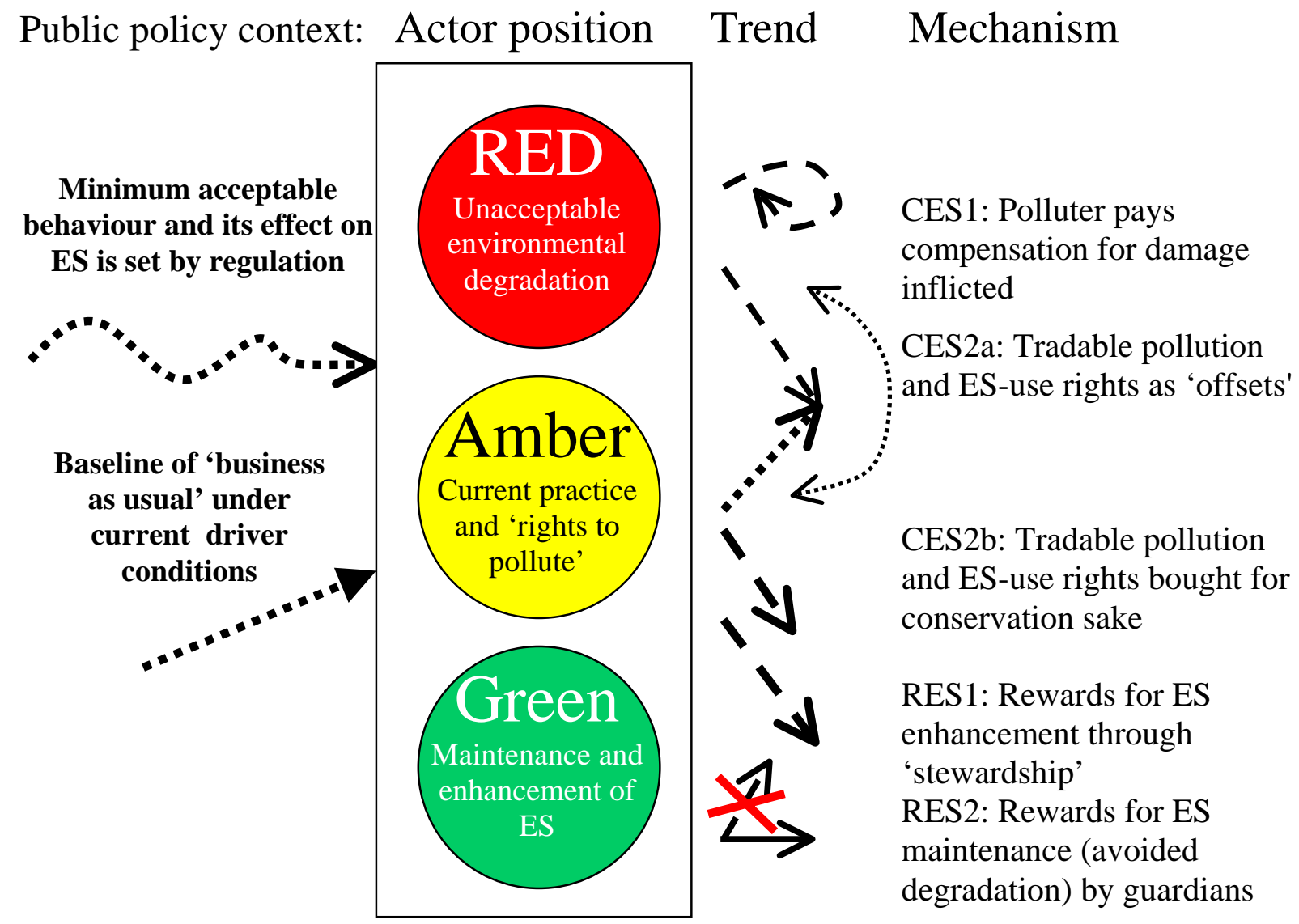

Figure 2. Conceptualization of the role of the four types of compensation and reward mechanisms in relation to existing regulation that defines 'minimum acceptable behaviour' (the border between red and amber) and current drivers of change that define the baseline 'business as usual' trajectory (modified from van Noordwijk et al. 2004b) 
For the current discussion we distinguish four types of compensation or reward mechanisms:

CES 1 operates in the red area, and is some form of 'polluter-pay' compensation for damage inflicted;

CES 2 is from the 'sellers' perspective based on partially unutilized rights to pollute or rights to a share of the environmental resource use (including hunting, logging or water use rights); from the buyers side it can be either (a) an opportunity for 'offset' transactions for buyers who otherwise would operate in the red zone (it includes 'cap and trade' mechanisms, such as allowed by the Kyoto Protocol), or (b) a buyer with a conservation objective who buys the rights in order not to utilize them (e.g. the conservation concession concept);

RES 1 operates from the transition of the yellow to the green zone and provides rewards for good 'stewardship';

RES 2 operates within the green zone and aims at avoiding losses and maintaining environmental qualities over and beyond existing legal protection.

In this paper the focus will be on the voluntary mechanisms CES 2, RES 1 and RES 2, but some of the economic valuation issues also refer to the non-voluntary CES 1 case. When referring to both 'compensation' and 'rewards', we will use CRES (compensation and rewards for environmental services) as shorthand notation.

The current debate on environmental services does not start with a blank slate. A patchwork of regulations and opportunities for positive reward schemes applies at different scales, which set the boundary conditions for any new or renewed concerns over environmental issues. Specifically, the options for voluntary, positive incentive schemes (rewards) are constrained by the current rules on 'minimum acceptable behaviour'. One can (or should) not be rewarded for what one is obliged to do. Where regulations and laws are substantially ahead of implementation and compliance, an approach based on positive incentives will likely require revisions of the regulatory framework as well.

Water may well be the environmental resource with the longest history of concerns over the public/private nature of the effects of land use. Water governance institutions often started with a settlers' right that prevented newcomers from disturbing water flows to existing farms or households, but evolved towards more equitable sharing of rights and responsibilities. Hunting rights have a long history of political contest, appropriation and regulation, which only gradually evolved into current concerns on wildlife conservation, as a starting point for broader biodiversity conservation. Climate change, greenhouse gas emissions and carbon stocks have been a concern of the last two decades only, and thus have been more able to make a 'fresh' start in establishing governance regimes. However, the slate is not completely clean. The land-use related components of these issues via fire and smoke/ haze have a longer history of regulation. Existing regulation of 'forest' as a land cover with restrictions based on concerns about water, timber resources and biodiversity conservation also implies a complex 'inheritance' for climate change institutions. This complex inheritance is part of the reason that the 'newer' part of energy-related emission reductions were institutionally easier to incorporate in international climate agreements than 'avoided emissions' and 'terrestrial carbon storage'. This in part explains why there still is no protocol on avoided deforestation under the UN Framework Convention on Climate Change, although its relevance, with at least $20 \%$ of current net emissions, is not debated. 


\subsection{Poverty dimensions and CRES institutions}

Kallesoe et al. (ICRAF Working Paper no. 36) review a number of asset and flow-based dimensions of poverty and their interactions with environmental service issues of relevance to local and external stakeholders. In the context of the livelihood analysis framework (Carney 1999), poverty can be defined as a critical lack in any of the five main capital types (natural, human, social, physical and financial) that leads to vulnerability. In the relationship between a local community and its outside world, we can distinguish relationships based on 'goods' and 'services' (Figure 3), with the markets for goods as a way for converting natural capital to financial capital and the markets for services generally failing to do the same. Changes in services, however, often have marked negative and occasionally positive impacts on 'political capital' (treated as the 'vertical' subset of social capital), as it affects other stakeholders.

Poverty, interpreted here as critical lack in any of the essential assets, appears by definition to be linked to lack of control over the production of environmental services. Rewards for environmental services which primarily target the stakeholders with formally recognized control over the services (or the natural capital that helps generate the services) may well enhance rather than reduce existing inequity. In fact, part of current poverty in rural areas is directly linked to the 'solutions' that have been developed to secure the supply of environmental services to stakeholders who have greater political clout. In large parts of the world a forest regulatory framework (Box 1) has developed that sets aside larges areas of land for 'public' functions that are, at least in the public perception, linked to environmental services (water flow and watershed protection, biodiversity conservation). The existing framework is a result of the historical processes of institutional reform and often underrepresents the interests of local stakeholders. Replacing 'hard' regulatory frameworks by 'softer' voluntary and conditional reward schemes may be a major contribution to poverty reduction.

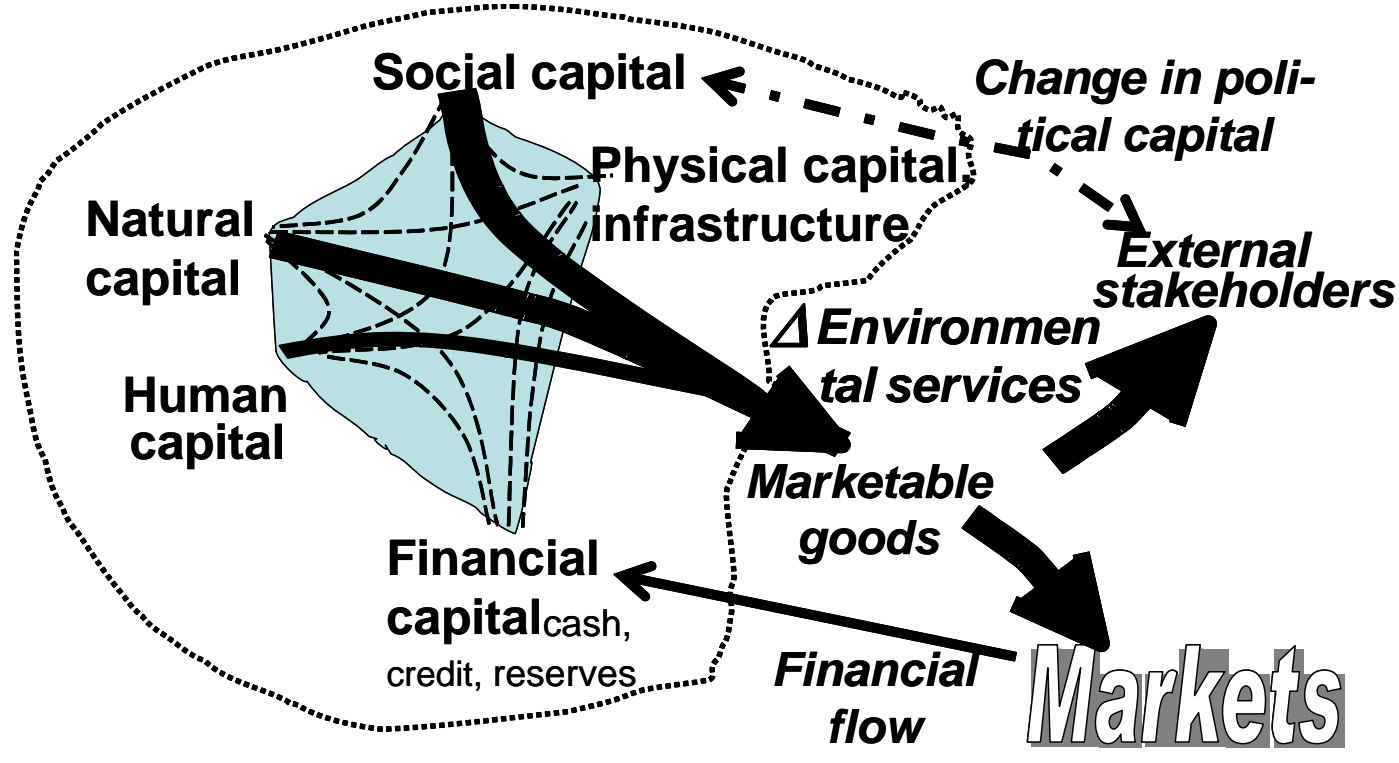

Figure 3. Conceptualization of the 'production function' of changes in environmental services, alongside the production of marketable goods, utilizing five types of capital (modified from Tomich at al. 2004a)

Poverty is directly linked to the profitability of the locally relevant range of land-use options, which depends on labour availability and wage rates, land prices, local know-how, access to markets and the current process for linking inputs and outputs as externally determined. These local determinants of 'profitability', however, depend on the 
existing regional or national context, under the influence of at least five policy domains (Figure 4). Institutions for CRES may need to consider their interaction with each of these existing policy domains, rather than starting from scratch.

\section{Box 1. Forest classification systems in relation to poverty and environmental services}

In large parts of the world the word 'forest' is closely associated with the concept 'environmental services'. Any problem with water is in the public debate linked to 'deforestation' while the default approach to solving environmental problems is 'reforestation' - even though the monoculture blocks of fast growing trees that are usually the result of reforestation have little in common with the original natural vegetation of the site.

The word 'forest' means anything from a stack of wood, vegetation with trees, wilderness, hide-out for rebels, state or elite-controlled hunting and (timber) mining domain, medicine chest to regulator of water flows and storehouse of biodiversity. In fact, the word 'forest' has an interesting origin as indicator of state (or royalty) controlled hunting lands, rather than vegetation with trees. Excluding local people from access is, however, still a common consequence of a 'forest' indication on land use maps, often coinciding with a 'right' (or assumed right) by the state to grant concessions to outsiders for logging or even conversion to other land uses. The legal basis of such state claims, however, may be contested, as for example in the case of Indonesia where only a small fraction of forests has been legally confirmed to be 'state forest' (Contreras and Fay, 2005; on large areas of (former) forest land multiple claimants exist and have not resolved boundaries.

Many countries have adopted forest policies that distinguish between forest land designated for conversion to agriculture or plantation forestry, forest lands that can be used for wood production (under various degrees of restriction and management), forests for watershed protection, and forests for nature (biodiversity) conservation. The latter two categories usually preclude human settlement.

To farmers and local land users the 'domesticated forest' is of particular relevance, and often words that indicate 'garden’ are preferred to indicate ownership (Michon, 2005; Fay and Michon, 2005). The question whether or not these 'gardens' can actually provide environmental services at the level required by society may be seen by some audiences as an 'empirical question' that can be answered by data collection and monitoring; others, however, see debate on such issues as undermining the case for 'forest conservation'. Thus, efforts to secure environmental services often, unnecessarily, contribute to rural poverty by excluding large areas from local access.

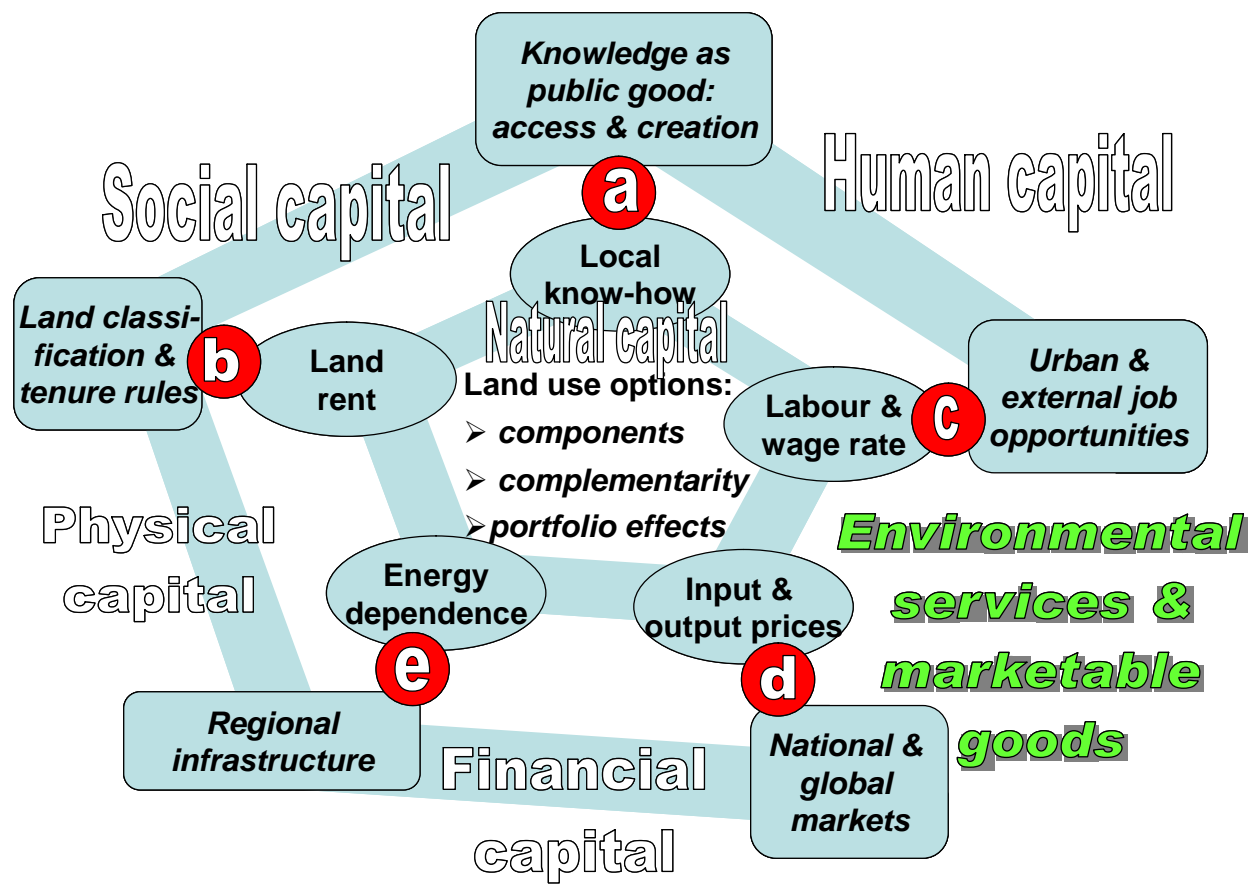

Figure 4. Schematic representation of the way the local profitability of land use options depends on the local levels of the five capital as well as at the national/global levels, with five policy domains (a...e) that influence the relation between local manifestation and national-scale characteristics: $\mathrm{a}=$ extension, $\mathrm{b}=$ land policies, $\mathrm{c}=$ non-agricultural sector development, $\mathrm{d}=$ market access and price policies and $\mathrm{e}=$ infrastructure and energy policies 
The broad concept of environmental service rewards in fact embraces considerable variation that relates to the type of service, the threat that has to be mitigated, controlled or avoided, and the type of stakeholders. While some generalizations can be made across the various services, especially at the institutional level, the specifics of the local 'issue' that has to be resolved matter a lot, and need to be taken into account at 'scoping', 'stakeholder identification'; and 'negotiation' stages (Figure 5).

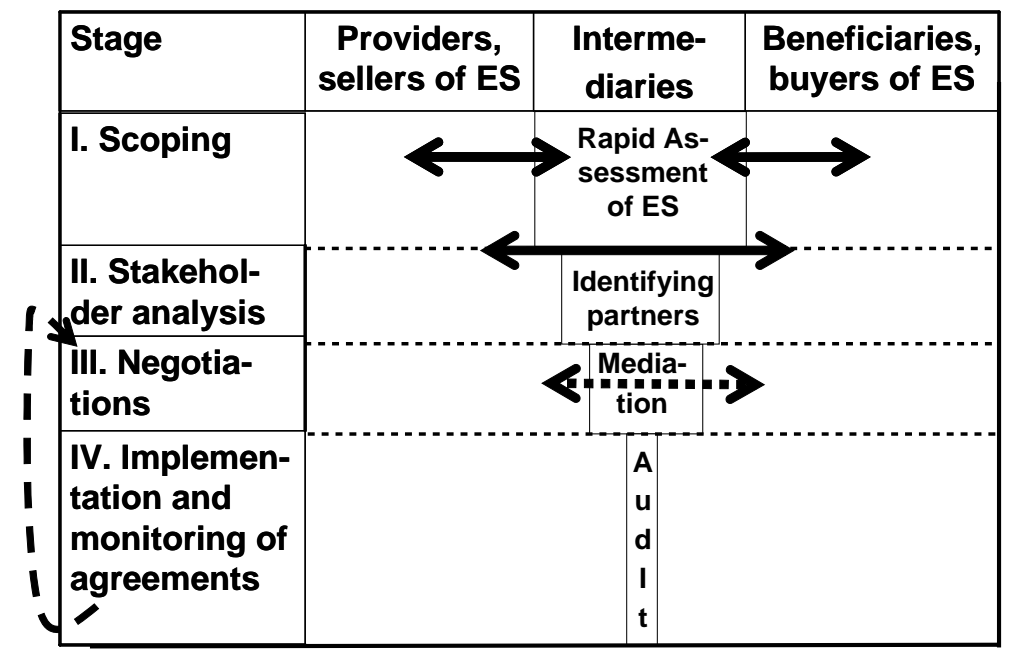

\section{Key questions:}

Would rewards be realistic? Is poverty linked to ES issues? Will they be voluntary? Who is/will be excluded? What conditionality will apply? Are the rewards 'pro-poor'? Effectiveness Efficiency Sustainability Equity

Figure 5. The four stages in voluntary ES agreements, the main roles of intermediaries and the key questions that need to be addressed

\subsection{Four stages in developing CRES}

The scoping stage clarifies how the ES provision is influenced by the changing of land cover and/or land practices. A basic assumption for 'rewards for environmental services' is that the supply of these services does depend on activities of those 'rewarded'. The perceptions of environmental functions and their processes among and between local people, local institutions, government and scientists play a key role in the negotiation for any environmental compensation scheme. This stage also will articulate knowledge, experience and perception of environmental functions and their processes among the stakeholders negotiating for a CRES.

The negotiation phase starts by identifying partners. Both providers and beneficiaries of ES determine the stakeholders involved in CRES. The providers begin to identify with whom they can communicate and prepare the documentation or 'projectization' that might be needed. On this stage, the role of intermediaries will be dominant in representing the actors involved effectively and equitably. This includes preparing formal and informal prerequisites for negotiation that expectedly will reduce the transaction cost borne by the sellers and buyers. Trust among multiple stakeholders can be developed in the negotiation. The providers will consider the tradeoffs between the rewards to be gained and the costs of having 'restrictions' or 'action' imposed to them. The buyers will calculate the risk and guarantee of project success. After negotiation is completed, the next step will be the implementation of the project according to the agreement. Finally, the last stage of a CRES scheme is monitoring and evaluation of the agreement. The sellers will need to recognize and deal with free riders or defectors of the process internally. Monitoring and evaluating tools are important to both sellers and buyers. The providers will need some information on whether they have complied with their contractual obligations. On the other hand, the buyers will require information about the results generated by the contract. 


\section{Rewards for Environmental Services: stakeholders, stages and agreements}

\subsection{Actors}

Elaborating on the conceptual framework of Swallow et al. (ICRAF Working Paper no. 32), we recognize four main actor groups, and linkages between two 'subsystems', the land use system that modifies the ES, and the subsystem of the beneficiaries of ES. There are two types of linkages: the condition of the (agro)ecosystem that generates the ES, and the set of regulations, recognition and rewards that provide feedback (or fail to do so...) from the beneficiaries to the modifiers.

\subsection{ES-modifiers, guardians and stewards as potential sellers}

Environmental services are emergent properties at landscape scale of a complex interaction between the natural capital of the site (including geomorphology, climate, biota, soils), land use aimed at increasing the flow of goods and services to the local land users, the network of filter functions within the landscape that modifies the impacts of field-level land use, and the social fabric of the community that constrains the decisions of individual households to use or modify local resources. The environmental services that are thus influenced consist largely of 'lateral flows' of water, (suspended) sediments, solutes, gases and particulate matter, and biota or energy that are perceived as beneficial or harmful outside of the area of primary influence. Local land-use decisions thus affect other stakeholders. Most of the 'environmental services' are seen as public goods and thus taken for granted until the time that they are affected and become scarce or of lower quality. The 'environmental issue cycle' (Figure 1) that then starts provides the background for opportunities for the modifiers to be compensated or rewarded.

ES reward mechanisms can start while the environmental condition is still good and where 'avoided degradation' is the key issue. They can also start in conditions of low environmental quality, where 'rehabilitation' is the key objective. Van Noordwijk et al. (2004) used the terms 'guardians' and 'stewards', respectively, for these two situations. In reality there may be elements of both guardianship (protecting remaining landscape elements of ES value) and stewardship (rehabilitating other parts of the landscape) in many ES reward applications. However, the discussions on the Clean Development Mechanism (CDM) have shown that the attribution issues are markedly different in avoided degradation and rehabilitation. In rehabilitation the positive efforts may be more easily compensated (especially where the 'baseline' is considered to be zero as in afforestation / reforestation for terrestrial carbon storage) than efforts to protect existing stocks (where the baseline rate of degradation is harder to define and agree upon). Also, avoided degradation needs to be assessed over large enough areas to allay concerns about 'leakage' (negative effects outside of the target area, but causally linked to the target area).

Generally, avoided degradation is linked to control over land, and is therefore primarily an opportunity for those who have secure control over substantial tracts of land generally not the poorest members of the local community. Rehabilitation may be more directly linked to labour, the primary resource of the rural poor. Therefore, the effects of ES reward schemes on poverty dimensions may thus differ substantially between 'avoided degradation' and 'rehabilitation' issues.

For much of the following discussion, it is important to start with a clear concept of the 'threat' that is either avoided or mitigated by the actions that are to be rewarded. Table 1 provides examples of such threats. 
Threats derived from land uses that are prohibited by existing regulations are, at least in theory, handled by the enforcement mechanisms of the existing regulations. In practice, however, may be a considerable gap between what is practiced and what is allowed.

However, for 'reward' mechanisms the point of departure must be what is technically allowed, unless the reward mechanism itself is shifting the boundaries of the regulatory domain. For a voluntary mechanism, the main issue for the modifiers of environmental services who consider forgoing the benefits that they can derive from a less-ES friendly land use practice, is the 'opportunity cost' (Table 2).

Table 1. Examples of threats to identified environmental services by land uses that may well be more (financially) profitable (from a private perspective) than more ES friendly alternatives

\section{Threat}

Loss of habitat: Conversion of natural forest (or other pre-human habitat) to less ES friendly land use

\section{Environmental service affected}

Protecting the integrity of conservation areas by preventing loss of habitat and threats at population level in the areas directly around core protection areas

Loss of habitat functions within agriculturally used landscapes

Providing habitat for a sub-set of the original fauna and flora inside agriculturally used landscapes

Direct threat to local biota by overharvesting

Direct threat to local biota by pollution (agrochemicals, organic wastes, mine spoils, industrial waste...)

Loss of habitat in corridors between protected areas

Maintaining connectivity between protected areas via corridors

Genetic erosion of useful tree, crop \& stock resources or their wild relatives

Loss of pollinators and pest control agents

Enhancing disease carriers

Creating opportunities for local-level

'restoration', in landscapes where connectivity is still maintained

Allowing extraction of potentially renewable resources

\begin{tabular}{l|l} 
Loss of landscape beauty in areas of high & Spiritual, religious and aesthetic values
\end{tabular} spiritual/aesthetic value

Loss of landscape beauty in areas for active recreation

Erosion of local ecological knowledge

Reduction of stored carbon in natural forest or peat soils

Regulation of pests and diseases

Reduction of stored carbon in agriculture/agroforestry areas

Opportunity for active recreation (ecotourism)

Ecological knowledge

Protecting natural forest area, peat soils and other carbon storage areas

Protecting above- and/or belowground carbon stocks in areas used for (agro)forestry and/or agriculture

Increasing net emission of greenhouse gasses

Accumulating terrestrial carbon stocks

Generation of smoke and haze, affecting

Detoxification of air, water, food

human health

Changing vegetation to one with greater water use

Water transmission (total water yield per unit rainfall)

Increase local water use trough irrigation Compaction of topsoil reducing infiltration and thus enhancing overland flow leading to flash floods

Compaction of topsoil reducing infiltration and reducing low flows from stored reserves

Buffering (above average river discharge per unit above average rainfall)

Gradual release of stored water supporting dryseason flows 


\begin{tabular}{|c|c|}
\hline Threat & Environmental service affected \\
\hline $\begin{array}{l}\text { Enhancing drainage and thus reducing gradual } \\
\text { release of water in dry periods }\end{array}$ & $\begin{array}{l}\text { Gradual release of stored water supporting dry- } \\
\text { season flows }\end{array}$ \\
\hline $\begin{array}{l}\text { Erosion leading to water pollution and } \\
\text { downstream sedimentation }\end{array}$ & $\begin{array}{l}\text { Maintaining water quality (relative to that of } \\
\text { rainfall) }\end{array}$ \\
\hline Erosion: transfer of soil fertility & $\begin{array}{l}\text { Tolerable intensities of net soil loss from slopes } \\
\text { by erosion }\end{array}$ \\
\hline Reduction of existing filter functions & \multirow{2}{*}{$\begin{array}{l}\text { Maintaining water quality (relative to that of } \\
\text { rainfall) }\end{array}$} \\
\hline Pollution of water resources & \\
\hline $\begin{array}{l}\text { Destabilizing slopes (undercutting slopes, } \\
\text { killing trees with anchoring roots) }\end{array}$ & Stability of slopes, absence of landslides \\
\hline Removing windbreaks & $\begin{array}{l}\text { Microclimate effects on air humidity and } \\
\text { temperature }\end{array}$ \\
\hline
\end{tabular}

Table 2 Opportunity costs in dependence of relative profitability of ES-threatening and ESfriendly land use practices

\begin{tabular}{|c|c|c|c|}
\hline \multicolumn{3}{|c|}{ Opportunity cost of enhancing $E S$} & \multirow{2}{*}{$\begin{array}{l}\text { Follow up questions: } \\
\text { Opportunity costs are apparently high - voluntary } \\
\text { ES reward schemes will be expensive; are non-land } \\
\text { use economic options exhausted? }\end{array}$} \\
\hline 1 & $\begin{array}{l}\text { Land use enhancing ES is much less } \\
\text { remunerative than current practice }\end{array}$ & & \\
\hline 2 & $\begin{array}{l}\text { Land use enhancing ES is less } \\
\text { remunerative than current practice }\end{array}$ & & $\begin{array}{l}\text { This is the classical 'opportunity cost' situation, } \\
\text { where further quantification is needed (see 5.1) }\end{array}$ \\
\hline 3 & $\begin{array}{l}\text { Land use enhancing ES is approximately } \\
\text { as remunerative than current practice }\end{array}$ & & $\begin{array}{l}\text { What will it take to 'tip the balance' in farmer } \\
\text { decision making }\end{array}$ \\
\hline 4 & $\begin{array}{l}\text { Land use enhancing ES is in fact more } \\
\text { remunerative than current practice }\end{array}$ & N.B & $\begin{array}{l}\text { What stops farmers from using those better } \\
\text { practices? }\end{array}$ \\
\hline 5 & $\begin{array}{l}\text { Land use enhancing ES is much more } \\
\text { remunerative than current practice }\end{array}$ & N.B & Are you sure? What stops farmers from doing it?? \\
\hline
\end{tabular}

\subsection{ES Beneficiaries as potential buyers}

When specific environmental services can no longer be taken for granted as public goods or 'birth rights', securing these services by imposing restrictions on those that negatively affect them is the obvious strategy of first choice for ES beneficiaries. However, it may be politically opportune or necessary for ES beneficiaries at least be seen to take a share in the responsibility - as many, if not all, beneficiaries are themselves also modifiers of ES. Beneficiaries of the ES can become 'buyers', 'providers of rewards' or 'providers of compensation.' Besides their interests in ES, beneficiaries may also have other motivations to engage in a relationship with ES modifiers, including moral concerns, legal obligations, and/or trading opportunities. The latter can be primarily aimed at the reputation of the individual or company, or at the actual continued access that the relationship provides to environmental services (Suyanto et al. 2006, van Noordwijk 2005). Table 3 suggests a sequence of response options to scarcity of environmental services. 
Table 3 Stereotyped list of preferences of ES beneficiaries

\begin{tabular}{|l|l|l|}
\hline Level & $\begin{array}{l}\text { Securing the environmental services required } \\
\text { for 'business as usual' }\end{array}$ & External relations \\
\hline $\mathbf{1}$ & $\begin{array}{l}\text { Appreciate ES as public good or, preferably, as 'club } \\
\text { good' accessible only to 'members of the club' }\end{array}$ & Keep low profile \\
\hline $\mathbf{2}$ & $\begin{array}{l}\text { Put pressure on government to enforce rules so that ES } \\
\text { can be or remain available as public good or as } \\
\text { accessible 'club good' }\end{array}$ & Keep low profile \\
\hline $\mathbf{3}$ & $\begin{array}{l}\text { Reduce dependence on ES by shift in location, use of } \\
\text { alternative resources or production methods }\end{array}$ & Keep low profile \\
\hline $\mathbf{4}$ & $\begin{array}{l}\text { Invest in environmental education and awareness so } \\
\text { that ES can be available as public good or as accessible } \\
\text { 'club good' }\end{array}$ & $\begin{array}{l}\text { Publicize the efforts to increa- } \\
\text { se market share }\end{array}$ \\
\hline $\mathbf{5}$ & $\begin{array}{l}\text { Invest in 'rehabilitation' efforts so that, after a recovery } \\
\text { period, ES will become available as public good or as } \\
\text { accessible 'club good' at low cost }\end{array}$ & $\begin{array}{l}\text { Publicize the efforts to increa- } \\
\text { se market share }\end{array}$ \\
\hline $\mathbf{6}$ & $\begin{array}{l}\text { Voluntarily provide long-term conditional, realistic } \\
\text { rewards for avoided degradation, to maintain access to } \\
\text { ES as 'club goods' }\end{array}$ & $\begin{array}{l}\text { Secure forms of 'eco label' as } \\
\text { protection for future criticism, } \\
\text { or for active PR efforts }\end{array}$ \\
\hline $\mathbf{7}$ & $\begin{array}{l}\text { Pay tax to (local) government with earmark to ensure } \\
\text { availability of ES as public good }\end{array}$ & $\begin{array}{l}\text { Guard against 'free riders' as } \\
\text { competitors }\end{array}$ \\
\hline $\mathbf{8}$ & $\begin{array}{l}\text { Pay general tax to (local) government and hope that it } \\
\text { will use part for ensuring availability of ES as public } \\
\text { good }\end{array}$ & $\begin{array}{l}\text { Complain about high and } \\
\text { unreasonable tax }\end{array}$ \\
\hline
\end{tabular}

Binning et al. (2002) recognized three mechanisms for securing the investment of ES buyers. Firstly, direct public (government) investment for conserving the environment. This type of investment mostly works in developed countries where the government budgetary investment is secured and committed, under the influence of public debate and involvement of politicians. Secondly, voluntary private investment involving corporations and other private entities from various industrial sectors. Mulder et al. (2006) listed the motivations of the private sectors to voluntary engage in ES reward schemes. These are the existence of business opportunities, security in reducing the cost of natural resource inputs, security in the license to operate by managing potentially difficult relationships, increasing the price of land, management of reputational risk under 'green' or environmental-friendly branding, pride and morale, and corporate commitment. The Mulder et al. study also revealed that the corporations that are currently involved in ES investment are mostly perceived to be frontrunners in their sectors. Interestingly, some financial institutions recognize that investing in socially and environmentally friendly businesses carries lower-than-average risk (Mulder et al. 2006). Yet, there is no hard proof that voluntary ES investments generate good payoffs through 'internalizing the externalities'. Thirdly, regulated private investment involves trading of rights to environmental resources (CRES 2 mechanism in Figure 2). Caps or limits on resource use create scarcity, form the basis for investment and encourage trade. Waage et al. (2006) found that a lack of buyers is the main barrier to fully actualize ES reward schemes that are designed in the public interest. Lack of awareness in the early stages of the scheme, combined with perceptions of risk and lack of clarity on the impacts on ES provision, can be expected. Only if stronger evidence of the business benefits of investment in ecosystem services becomes available, can private sector buyers be expected to become voluntarily involved beyond the few 'showcases' that their public relations professionals need. The bottom line for ES buyers suggests that they should invest only if the opportunity costs 
set by alternative service providers exceed the costs expected per unit gain in a particular ES and/or location.

\subsection{ES intermediaries}

A simple criterion for CRES thus relates the emergence of voluntary transactions to a comparison of the opportunity costs for potential sellers and buyers. If the latter sufficiently exceeds the first, the unavoidable 'transaction costs' can be covered, and there may be room for net benefits, to be bargained between sellers, intermediaries and buyers (Figure 6). It is important to note, however, that the 'opportunity costs' for both buyer and seller depend on existing regulatory frameworks that define the scarcity of former public goods and limit the range of land-use options that can be considered.

ES intermediaries, institutions or individuals who link potential ES sellers and buyers play major roles in reducing 'transaction costs', at least in the early stages of CRES mechanisms. Three roles of ES intermediaries are generally recognized in bridging this sellerbuyer relationship. First, intermediaries are considered as ES supporters who can clarify the 'real interests' of potential buyers and sellers in scoping and stakeholder analysis stage and facilitate negotiations to speed up agreements. Second, intermediaries can act as public advisors who give opinions to influence regulatory frameworks or the decisions or actions of other stakeholders in the process. Third, intermediaries can be involved as certifiers who (formally) confirm and guarantee the robustness of contracts

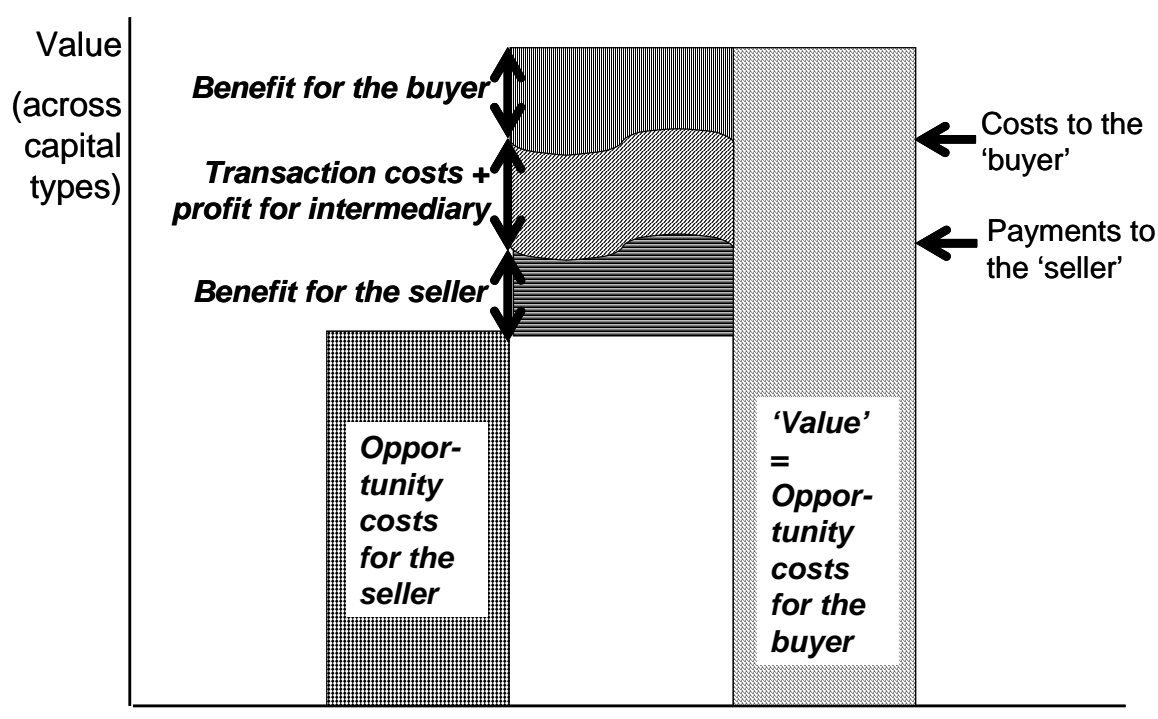

Figure 6. Schematic representation of the value chain: if the opportunity costs for the seller exceeds the opportunity costs for the buyer + unavoidable transaction costs, no transaction is likely to take place; if there is space for negotiations, the benefits will be shared between buyer, intermediary and seller, depending on their strength in the negotiations

The first role of intermediaries requires a balancing act between the interests of potential ES sellers and buyers, establishing trust with (and between) both sides of the negotiation. In the long run, a reputation of specific intermediaries as 'honest brokers' is the main incentive for them to do high quality work. In the early stages of CRES mechanisms, however, intermediaries may be attracted to the possibilities of maximizing profit margins.

Intermediary stakeholders involved in ES scheme can be multi-layered and multiscaled. ES sellers and buyers possibly range from individuals to aggregates of individuals or institutions (Figure 7). ES sellers ultimately are large numbers of individuals / households in the uplands or other rural areas - who will already be involved in various types of community- 
level organizations. These grass-root organizations can also serve as intermediaries in representing individual sellers. ES buyers can be single organizations, such as a private company in a carbon sequestration scheme. On the other side, buyers may consist of large numbers of individuals, which usually operate as a 'bundle', such as the domestic water users organized by a water-consumer association.

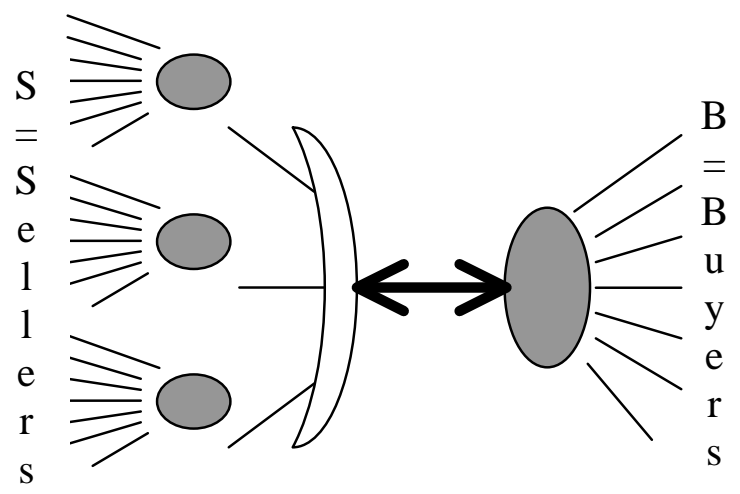

Seller $\Leftrightarrow$ Intermediaries

Intermediaries $\Leftrightarrow$ Buyer

Figure 7. Schematic view of the interactions between buyers, intermediaries and sellers

As a consequence, intermediaries can operate at different scales as well. In one extreme, an individual farmer freely negotiates an agreement(s) with the buyer(s) for each piece of land, in which case a seller absorbs all 'intermediary' roles. The other extreme condition is that a uniform agreement is applied to a large number of people owning large tracts of land, in which the buyer imposes itself as 'intermediary'. In between, the intermediary role can refer to small or large groups, with varying degrees of differentiation between group members in the details of agreements.

Adapting from Griffin (1991), Kuperan et al. (1998) and Challen (2000), Mburu et al. (2003) distinguished transaction costs into three categories: (1) search and information costs; (2) bargaining and decision or contracting costs, and (3) monitoring, enforcement and compliance costs. The first two categories of costs occur before the institutional arrangements for collaborative management of natural resource are made. Therefore, the first and second categories are referred as ex-ante (investment) costs and ex-post (operational) costs for the third category.

The overall transaction cost can be broken down into two components (1) transaction cost covering interactions between buyers and intermediaries $(B \Leftrightarrow I)$ and $(2)$ transaction costs covering interactions between sellers and intermediaries $(\mathrm{S} \Leftrightarrow \mathrm{I})$. As illustrated by Figure 8, it can be expected that the transaction cost of $B \Leftrightarrow I$ will decrease as the scale of the intermediary increases. The reason is that larger scale intermediaries allow buyers to more easily deal with larger tracts of land or larger quantities of ES in single transactions. However, intermediaries will have more difficulties in dealing with larger numbers of individual farming household as ES sellers. Therefore, the $\mathrm{I} \Leftrightarrow \mathrm{S}$ transaction cost will increase.

We may expect that the total transaction costs are minimized at some scale of organization in between the two extremes. This is the 'optimum' scale of I from a buyer and seller perspective - it may, however, not be the optimum one from the business perspective of intermediaries. Under certain circumstances a combination of two 'brokers', one representing buyers and one representing sellers may be more effective than a single one. When we separate the 'negotiation' and 'implementation' phases, we may expect that the I $\Leftrightarrow$ $\mathrm{S}$ transaction cost is more strongly scale dependent, and as a consequence, the optimum scale of I shifts to the left. 


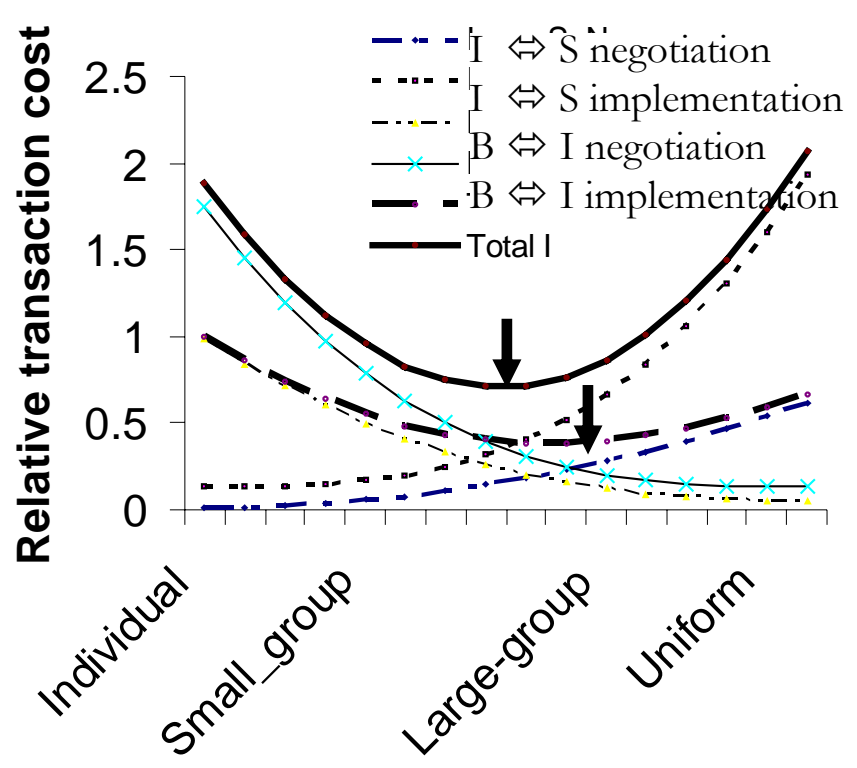

Figure 8. The way the components of transaction costs depend on the scale of 'sellers'

\subsection{Government roles: regulator}

'Pro-poor' approaches to CRES can spontaneously arise from private sector involvement, or (more often) be supported by public sector involvement in CRES. Governments or the public sector can potentially play four roles in the interactions between sellers (providers) and buyers (beneficiaries) of ES. They can act as 1) buyer on behalf of 'downstream' stakeholders, 2) seller in international interactions, 3) intermediary or 4) market regulator. While different levels of the public sector or government can be involved in these different roles, a clear separation of roles is expected to be needed for transparency and public control (Figure 9).

The government's primary role as 'marker regulator' needs to be reflected across a range of scales from the local community to the national scale, with international conventions as an umbrella for cross-boundary issues. Depending on the degree and success of 'decentralization', the different levels of government may either support each other in this role across scales, or, more often, contest overlapping authorities and thus substantially add to transaction costs.

Unfortunately, much of the existing regulation can be interpreted as not maximizing overall efficiency, but as maximizing opportunities for rent seeking for intermediaries (where intermediaries help to smooth the pathway through a regulatory jungle). Where government entities that regulate also (intend to) operate as an ES seller (e.g. forestry departments in applications of the 'clean development mechanism') public scrutiny of the conglomeration of roles is warranted. 

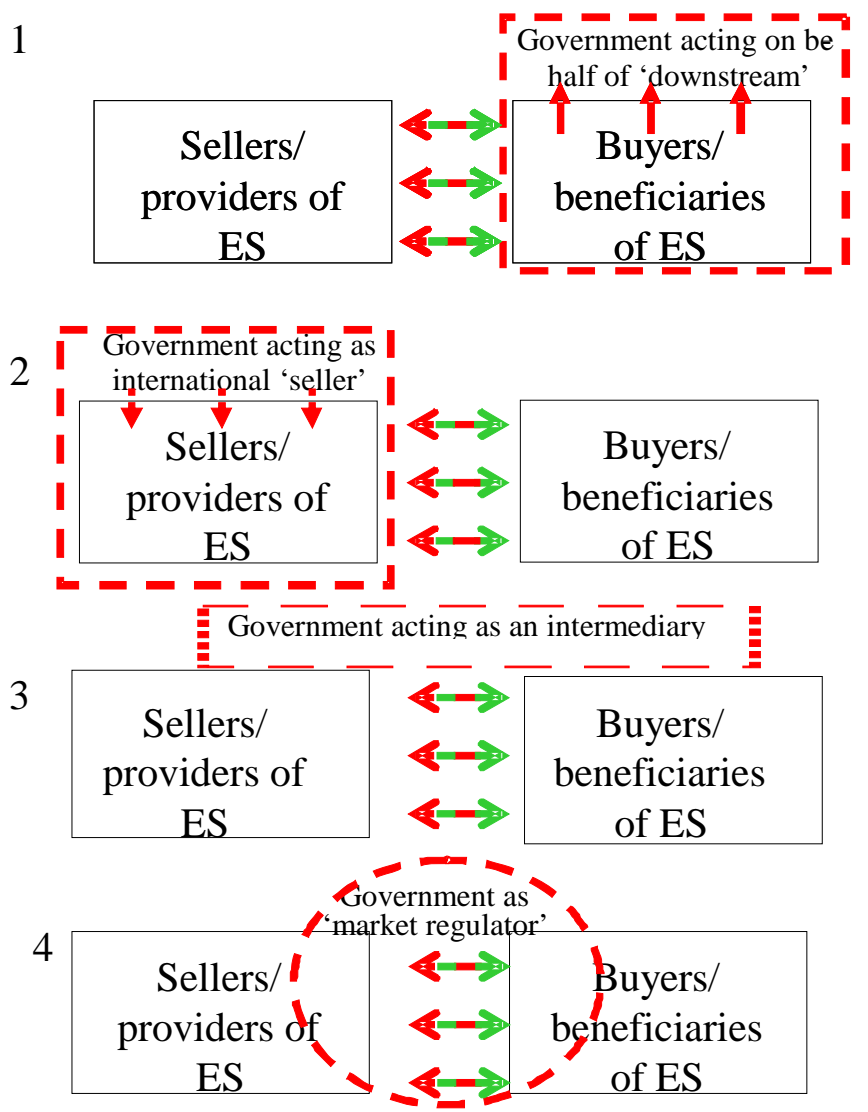

Figure 9. Four main roles that the government (public sector) can play relative to private sector involvement in CRES

A major long-term role for a public sector regulator of CRES agreements is to provide mechanisms for litigation. Conditionality in CRES can refer to essentially five 'levels': objecttives, management plans, activities, condition of the agro-ecosystem, or actual ES outcomes (Figure 10). The last of these levels are the closest to the interests of external agents, but the time lags and difficulties of attribution of effects in the presence of substantial variation in 'natural' events, often leads to a focus on 'activities' as the basis for CRES. Detailed prescriptions of activities will have the inefficiencies of 'micro-management', and a shift to higher order 'management plans' may be appropriate. Finally, a basic agreement on the objectives and criteria that drive management plans may be the preferred basis for CRES, if sufficient trust has been established. 


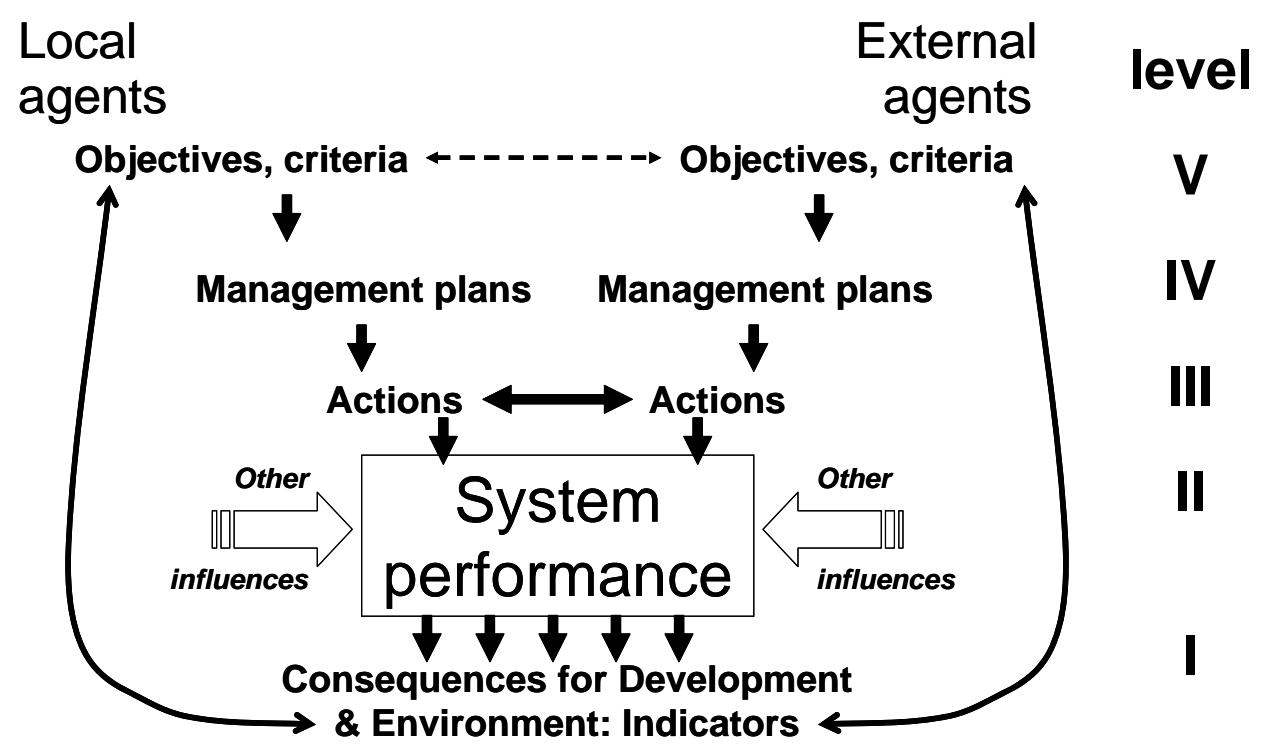

Figure 10. Five levels at which agreements on ES Reward schemes between local and external actors can be based: I. Consequences for the ES, II. Condition of the agroecosystem, III.Human activity, IV. Management plans or V. Management objectives (modified from van Noordwijk et al. 2004b)

\section{Criteria for rewarding environmental services}

\subsection{Criteria and actor perspectives}

The key questions formulated in Figure 5 can now be grouped under two classes of criteria. The first class relates to the effectiveness, efficiency and sustainability of the CRES institutions, with the environmental services as the primary target and criteria that relate to three questions. Again, these are questions are: Would rewards be realistic? Will they be voluntary? What conditionality will apply?. We postulate that the 'realistic' question will predominate in the scoping stage; the 'voluntary' question will predominate in the stakeholder analysis and negotiation stage; and the 'conditionality' question will predominate in the implementation stages. The second class of criteria is aimed at the equity dimension (Is poverty linked to ES issues? Who is/will be excluded? Are the rewards 'pro-poor'? that predominate in the scoping, stakeholder analysis and negotiation + implementation stages, respectively) 
Table 4. Four categories of criteria for CRES, viewed from the perspective of buyers, intermediaries, sellers and regulators.

\begin{tabular}{|c|c|c|c|c|}
\hline & \multicolumn{3}{|c|}{ A. Effectiveness, Efficiency and Sustainability } & B. Equity \\
\hline $\begin{array}{l}\text { Criterion } \\
\text { Stage } \\
\text { Role } \\
\end{array}$ & $\begin{array}{l}\text { I. Realistic } \\
\text { Scoping }\end{array}$ & $\begin{array}{l}\text { II. Voluntary } \\
\text { Stakeholder } \\
\text { analysis }\end{array}$ & $\begin{array}{l}\text { III. Conditional } \\
\text { Negotiation } \& \\
\text { implementation } \\
\end{array}$ & $\begin{array}{l}\text { IV. Pro-poor } \\
\text { All stages }\end{array}$ \\
\hline General criterion & $\begin{array}{l}\text { Effectively mitigates, } \\
\text { reduces or avoids } \\
\text { threats to ES for all } \\
\text { parties involved }\end{array}$ & $\begin{array}{l}\text { Engagement in- } \\
\text { volves choice rather } \\
\text { than being the } \\
\text { object of regulation }\end{array}$ & $\begin{array}{l}\text { Service and rewards or } \\
\text { compensation are dyna- } \\
\text { mically linked }\end{array}$ & $\begin{array}{l}\text { Mechanisms selected } \\
\text { are positively biased to- } \\
\text { wards disadvantaged } \\
\text { stakeholders }\end{array}$ \\
\hline $\begin{array}{l}\text { Modifier/Seller: } \\
\text { As guardian or steward } \\
\text { of environmental } \\
\text { services } \\
\text { Seeking } \\
\text { Local ES plus livelihood } \\
\text { options with minimum } \\
\text { reduction in freedom and } \\
\text { optimum rewards for } \\
\text { efforts and assets }\end{array}$ & $\begin{array}{l}\text { Sellers also may have a } \\
\text { stake in tangible, } \\
\text { sustainable } \\
\text { environmental services. } \\
\text { For true public goods, } \\
\text { for example, sellers } \\
\text { also have a stake as } \\
\text { beneficiaries }\end{array}$ & $\begin{array}{l}\text { Rewards offset (at } \\
\text { least) the real } \\
\text { opportunity costs } \\
\text { and any } \\
\text { organizational costs } \\
\text { or risks of pro- } \\
\text { viding the ES that } \\
\text { are borne by sellers }\end{array}$ & $\begin{array}{l}\text { Monitoring and } \\
\text { enforcement mechanisms } \\
\text { retain discretion regar- } \\
\text { ding production and } \\
\text { investment decisions } \\
\text { Sellers' obligations end if } \\
\text { conditions governing } \\
\text { rewards for ES are not } \\
\text { met... } \\
\text { Risks are borne by } \\
\text { intermediaries or buyers }\end{array}$ & $\begin{array}{l}\text { Potential sellers may be } \\
\text { poor, but otherwise be } \\
\text { excluded } \\
\text { Relatively well-off } \\
\text { sellers may seek to } \\
\text { include the poor if poor } \\
\text { people can threaten } \\
\text { process of reaching or } \\
\text { sustaining CRES } \\
\text { programs }\end{array}$ \\
\hline $\begin{array}{l}\text { Beneficiary/ buyer: } \\
\text { Seeking } \\
\text { Actual flows of en- } \\
\text { vironmental services } \\
\text { and/or } \\
\text { 'Certified / tradable units } \\
\text { of pollution abatement' } \\
\text { and/or } \\
\text { 'Market share based on } \\
\text { social and environmental } \\
\text { reputation' }\end{array}$ & $\begin{array}{l}\text { Tangible, sustainable } \\
\text { environmental service } \\
\text { benefits of the ES exist }\end{array}$ & $\begin{array}{l}\text { Costs of obtaining } \\
\text { ES benefits and } \\
\text { associated risks are } \\
\text { less than } \\
\text { comparable } \\
\text { alternatives } \\
\text { Although impo- } \\
\text { sition of regulation } \\
\text { might appear to be } \\
\text { an easier route to } \\
\text { obtaining ES, vo- } \\
\text { luntary agreements } \\
\text { may be more sus- } \\
\text { tainable }\end{array}$ & $\begin{array}{l}\text { Efficient, effective and } \\
\text { transparent: mechanisms } \\
\text { for monitoring, } \\
\text { verification, and } \\
\text { enforcement are needed } \\
\text { Buyers' obligations end if } \\
\text { conditions governing } \\
\text { supply of ES are not met } \\
\text { Risks are borne by } \\
\text { intermediaries or sellers }\end{array}$ & $\begin{array}{l}\text { Positive: buyers benefit } \\
\text { (ethically, politically or } \\
\text { by reputation) from be- } \\
\text { neficial social as well as } \\
\text { environmental impacts } \\
\text { Negative: If not included } \\
\text { in RES, poor people } \\
\text { may constitute an } \\
\text { additional threat to ES } \\
\text { supply }\end{array}$ \\
\hline $\begin{array}{l}\text { Intermediary/ } \\
\text { broker/certifier } \\
\text { Matching buyers and } \\
\text { sellers, efficient handling } \\
\text { of all steps to reduce } \\
\text { transaction costs and risks } \\
\text { and/or } \\
\text { Providing credibility and } \\
\text { legitimacy based on ca- } \\
\text { pabilities, reputation and } \\
\text { trust' } \\
\text { and/or } \\
\text { Concern with } \\
\text { environmental issues }\end{array}$ & $\begin{array}{l}\text { There are sufficient } \\
\text { values accruing from } \\
\text { environmental services } \\
\text { to support the } \\
\text { development of a } \\
\text { market or payment } \\
\text { mechanism }\end{array}$ & $\begin{array}{l}\text { Sufficient values can } \\
\text { be captured from } \\
\text { the beneficiaries of } \\
\text { environmental ser- } \\
\text { vices to cover the } \\
\text { transactions costs of } \\
\text { implementing } \\
\text { CRES and cost of } \\
\text { rewards to suppliers } \\
\text { and/or } \\
\text { Other organizations } \\
\text { are willing to } \\
\text { subsidize these } \\
\text { services in the } \\
\text { public interest }\end{array}$ & $\begin{array}{l}\text { Monitoring and } \\
\text { enforcement mechanisms } \\
\text { are efficient and effective, } \\
\text { thereby reducing transac- } \\
\text { tion costs } \\
\text { If intermediaries bear } \\
\text { risks for non-compliance } \\
\text { from either side, they are } \\
\text { compensated for those } \\
\text { risks or can insure against } \\
\text { them to reduce exposure } \\
\text { to risks }\end{array}$ & $\begin{array}{l}\text { Social conditions that } \\
\text { induce intermediaries to } \\
\text { seek pro-poor results } \\
\text { are similar to those for } \\
\text { buyers } \\
\text { Intermediaries may } \\
\text { have an interest in pro- } \\
\text { moting pro-poor RES if } \\
\text { they believe this will } \\
\text { increase subsidies from } \\
\text { government or donor } \\
\text { organizations that, in } \\
\text { turn, will expand } \\
\text { opportunities for } \\
\text { intermediation }\end{array}$ \\
\hline
\end{tabular}




\begin{tabular}{|c|c|c|c|c|}
\hline $\begin{array}{l}\text { Criterion } \\
\text { Stage } \\
\text { Role }\end{array}$ & $\begin{array}{l}\text { I. Realistic } \\
\text { Scoping }\end{array}$ & $\begin{array}{l}\text { II. Voluntary } \\
\text { Stakeholder } \\
\text { analysis }\end{array}$ & $\begin{array}{l}\text { III. Conditional } \\
\text { Negotiation \& } \\
\text { implementation }\end{array}$ & $\begin{array}{l}\text { IV. Pro-poor } \\
\text { All stages }\end{array}$ \\
\hline $\begin{array}{l}\text { Regulator: securing } \\
\text { broader public interests in } \\
\text { social, economic and } \\
\text { environmental outcomes. } \\
\text { (Role may be filled by } \\
\text { government or informal } \\
\text { parts of civil society.) }\end{array}$ & $\begin{array}{l}\text { At any relevant scale } \\
\text { (international, regional, } \\
\text { local), resulting } \\
\text { patterns of activities } \\
\text { and investments indu- } \\
\text { ced by CRES schemes } \\
\text { need to be compatible } \\
\text { with broader en- } \\
\text { vironmental objectives } \\
\text { (avoidance of leakage } \\
\text { and/or perverse effects } \\
\text { on ES). }\end{array}$ & $\begin{array}{l}\text { Social and political } \\
\text { legitimacy of } \\
\text { negotiation and } \\
\text { implementation. }\end{array}$ & $\begin{array}{l}\text { Mechanisms for } \\
\text { negotiation, verification, } \\
\text { monitoring, enforcement, } \\
\text { and conflict resolution } \\
\text { must conform with } \\
\text { applicable legal and admi- } \\
\text { nistrative frameworks } \\
\text { and with social norms. }\end{array}$ & $\begin{array}{l}\text { Protect from negative } \\
\text { distributional effects } \\
\text { and elite capture. } \\
\text { Fundamental question: } \\
\text { why combine envi- } \\
\text { ronmental and poverty } \\
\text { objecttives? } \\
\text { Positive: more } \\
\text { resources in } \\
\text { combination than sum } \\
\text { of each taken alone. } \\
\text { Negative: avoidance of } \\
\text { potential social conflict } \\
\text { and political spillover. }\end{array}$ \\
\hline
\end{tabular}

\subsection{Realistic}

\subsubsection{Shared perception on causation of land use - ES effects}

The basis for any CRES is - or should be - a real cause-effect relationship between modified land use and environmental services that are considered to be of value. Although of obvious importance, this is not a trivial concern. Many current Payment for Environmental Services (PES) schemes appear to be based on correlations (e.g. between existing forest and provision of water) rather than on true cause-effect relationships (e.g. where planting trees is more likely to reduce total water yield, at least in the short to intermediate term), or unproven relationships between ecosystem conservation efforts and the actual provision of valuable environmental services. Increasing evidence exists that in many cases these ES provision and values are assumed, rather than real, for example in relation to watershed protection, bioprospecting and ecotourism (Calder 2001; Chomitz 1998; Reid 2001; Tognetti et al 2003; Rojas and Aylward 2003). Providers of ES, even intermediaries, in many cases do not know the real effects of their land management practices on the maintenance or improvement of ES provisions. Buyers of 'environmental services' often remain unaware of the ES provision they are receiving in return for their payments (or even that such values are being generated in the first place). In this sense, buyers of ES are often not different from general taxpaying public who may not get what they pay for when it comes to forest protection (Kaimowitz 2000). This lack of a clear relationship between the CRES mechanisms and the intentions is mostly caused by substantial differences of perception among stakeholders on the relation between land use and provision of ES. The communication on environmental issues, the complexity of cascading and cumulative interaction among stakeholders often leads to these differences.

Furthermore, the scientist's role in finding the clarity concerning how to address the complexity of landscape and ES provision interactions has not been fully accomplished. For example, in watershed cases, many downstream stakeholders still perceive that only 'full forest cover' can guarantee the functionality of watershed and that any type of deforestation is a threat. On the other hand, upland land users find that more open land cover types are more beneficial for their livelihood and can be made compatible with their local needs for watershed functions (Jeanes et al. 2006). Box 2 shows a study case on RUPES experience in Singkarak watershed in scoping these perceptions and their degree of overlap and similarity 
using the 'rapid hydrological appraisal' tool. A suit of appraisal tools for multiple stakeholder perceptions on ES is available (Table 5).

\section{Box 2. Bridging perception differences among stakeholders: Rapid Hydrological Appraisal of Lake Singkarak Watershed}

The rapid hydrological appraisal tool of Jeanes et al. (2005) was applied by Farida et al. (2005) in the Singkarak watershed in West Sumatra to analyze perspectives of a range of stakeholders-local communities, researchers and policy makers. A topic that appeared to be controversial is the effect of planting Pinus merkusii or other fast-growing evergreen tree species on the quantity of water supplied to the lake. Although these species were favoured by foresters for past 're-greening' efforts, water use by canopy interception and transpiration of such trees reduces total water yield to the lake, and the expected increase in regularity of flow through better soil structure will not fully compensate this effect.

The hydrological model pointed to a strong dependence of hydro-electricity production on variations in annual rainfall and possible increase of El Niño years with long dry seasons under the influence of global climate change. This effect exceeds that of local land cover change. The study pointed to the importance of maintaining water quality in the lake for all stakeholders, with concerns over sediment inflow, as well as nutrients and urban waste.

Reforestation efforts using appropriate tree species and focused on relevant 'erosion hotspot' locations can lower sediment influx to the lake and improve regularity of water flow, but not directly influence the number of operating days for the hydroelectricity company. As part of these findings were surprising to some of the stakeholders, good communication is needed to avoid overresponses on perceptions that reforestation is either sacred or evil. It requires 'the right tree in the right place'. Two years after the appraisal a number of significant shifts can be noted in the portrayal of the issue and in the type of solutions sought.

\begin{tabular}{|c|c|}
\hline $\begin{array}{l}\text { Before the Rapid Hydrological } \\
\text { Appraisal (RHA) }\end{array}$ & After RHA + follow up discussions \\
\hline $\begin{array}{l}\text { Deforestation seen as the main } \\
\text { culprit of all problems, including } \\
\text { blackouts }\end{array}$ & $\begin{array}{l}\text { Focus on lake \& its water quality; } \\
\text { adjust scale of institution } \\
\text { - } \quad \text { More awareness of climatic } \\
\text { dependence } \\
\text { - Less blaming the upland } \\
\text { deforestation for blackouts } \\
\end{array}$ \\
\hline - $\quad$ Tree planting as main solution & $\begin{array}{l}\text { - Less focus on 'tree planting' as the } \\
\text { only or main solution }\end{array}$ \\
\hline $\begin{array}{l}\text { Village with most tree cover } \\
\text { should get highest share in } \\
\text { royalties }\end{array}$ & $\begin{array}{l}\text { - More care in planning coffee re- } \\
\text { intensification (Kopi Ulu) }\end{array}$ \\
\hline $\begin{array}{l}\text { Problems with the endemic, edible } \\
\text { fish ('Ikan bilih') linked to } \\
\text { deforestation }\end{array}$ & $\begin{array}{l}\text { - Ikan bilih problem is about } \\
\text { breeding grounds \& overfishing }\end{array}$ \\
\hline
\end{tabular}


Table 5. Flow chart of a toolbox of appraisal methods currently under development at the World Agroforestry Centre (www.icraf.org/sea)

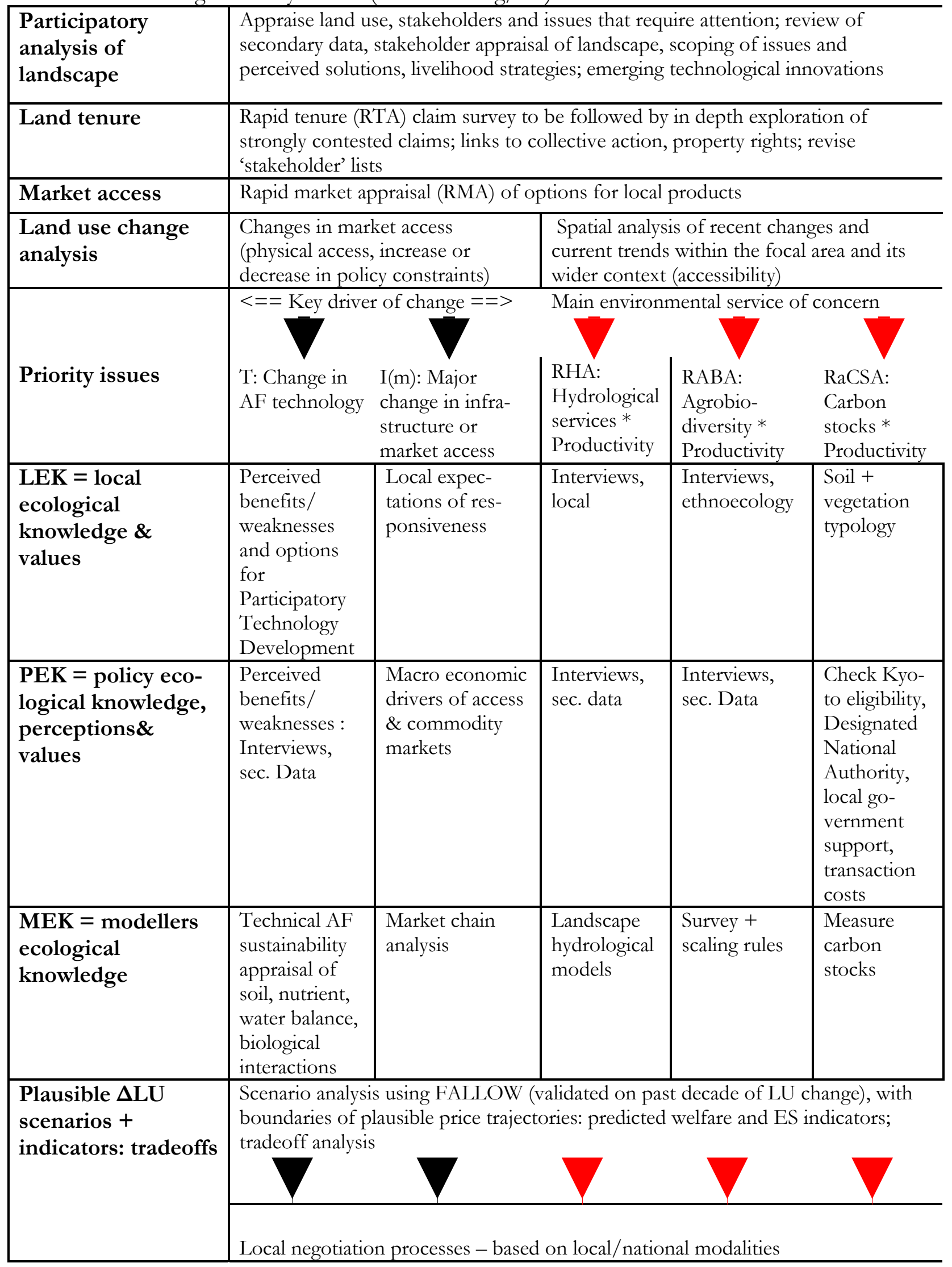


Across four categories of environmental value (biodiversity, carbon sequestration, landscape beauty and watershed function) four combinations of current condition and threat can be recognized (Table 6; van Noordwijk 2005).

Table 6. Simple classification of conditions and trends of environmental services in relation to the likely concerns of potential CRES

\begin{tabular}{|c|c|c|c|}
\hline & \multicolumn{2}{|l|}{ Condition } \\
\hline & & Good & Poor \\
\hline \multirow[t]{2}{*}{$\begin{array}{l}\text { Threat / } \\
\text { trend }\end{array}$} & $\begin{array}{l}\text { Low } \\
\text { constant }\end{array}$ & $\begin{array}{ll}\text { No } & \text { 'additionality' } \\
\text { expected } & \end{array}$ & Priority for 'restoration' \\
\hline & $\begin{array}{l}\text { High / } \\
\text { negative }\end{array}$ & $\begin{array}{l}\text { Priority for 'avoided } \\
\text { damage' }\end{array}$ & No 'permanence' expected \\
\hline
\end{tabular}
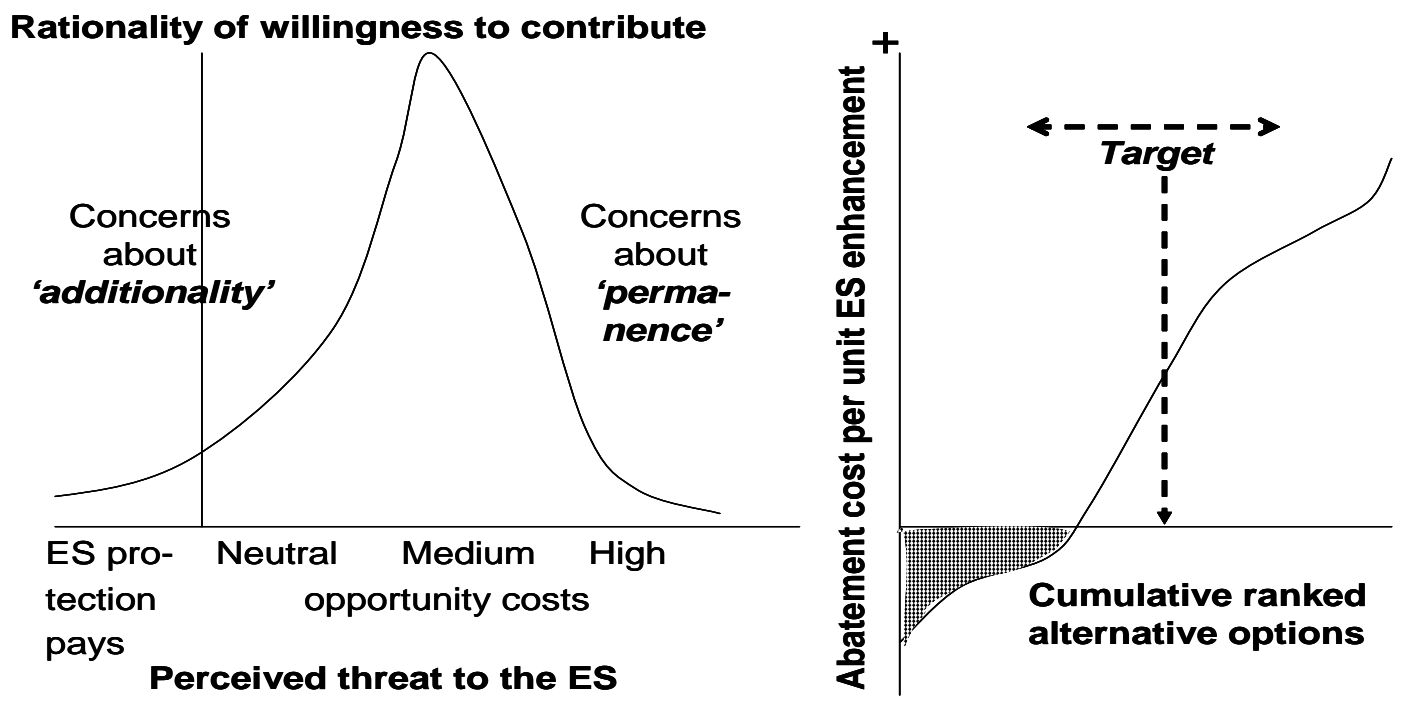

Figure 11. A. Conceptualization of 'optimal threat' in relation to 'willingness to contribute'; B. Cumulative abatement costs, suggesting domain of negative costs

Where the 'natural capital' is in good condition and strong threats exist, guardianship or 'avoiding damage' is likely to attract attention, such as in conserving biodiversity, protecting landscape beauty, reducing the probability of landslides, or maintaining clean air. Where positive human efforts can increase ES provision, such as in regulating water flows, enhancing quality of surface water and increasing carbon storage, restoration or stewardship is relevant. In the other two quadrants of Table 6 (good condition, low threat and poor condition, high threat), concerns for 'additionality' or 'lack of permanence' are likely to limit the willingness to contribute by potential ES buyers. Survey-base studies of 'willingness to pay' may need to be corrected for 'ability to pay' to become realistic estimators of this willingness to contribute and test the hypothesis embedded in Figure 11A. For a number of environmental issues it has been shown that part of the 'restoration' or abatement efforts will in fact be directly profitable, and thus in need of moral but not financial support (Figure 11B). The analysis by Tomich et al. 1996 of opportunities for use of Imperata grasslands in Indonesia may serve as example. This is an extreme case of 'lack of additionality'. Please note that such cases are the prime target for market agents under 'cap-and-trade' mechanisms, and the main reason for regulators to be wary of such mechanisms. A recent example may be found in one of the first and largest so far 'Clean Development Mechanism' transactions approved in India which provided Carbon Emission Reduction credits for a switch away from chlorinated 
fluorocarbons that was in fact mandated under the Montreal protocol ("in the special case of $\mathrm{HFC}_{23}$, carbon trading does introduce a perverse incentive which does challenge the environmental integrity of both Protocols" (Montreal and Kyoto) (Schwank 2004; Paul Appasamy personal communication, Asia Regional Workshop on Compensation for Ecosystem Services, Bangalore, India, 8-10 May 2006).

The Rapid Agrobiodiversity Appraisal tool (Kuncoro et al. 2006) includes appraisal of the perceptions of the current threat level to (agro)biodiversity relative to the 'optimum threat' level (Box 3).

\section{Box 3. Optimal level of threats to agro-biodiversity: not too high, not too low}

The Rapid Agrobiodiversity Appraisal (RABA) is an approach to appraise the location-specific biodiversity of a given agricultural landscape from a local as well as global perspective. It is based on the concept of 'integration' of functions that maintains substantial biodiversity within productive landscape. The RABA approach aims at making operational ES reward schemes, with full comprehension that competition exists between the 'conservation and 'economic development'.

The Rapid Agrobiodiversity Appraisal (RABA) was developed under the assumption that effective natural resource management, including biodiversity conservation, can only be achieved if there is a synergy between three different types of capital-human, natural and social. Threat is the combination of the value of the landscape (natural capital) perceived by both internal and external users of this landscape. The existence of traditional hunting, ethnic conflict, hunting laws and private land control for shifting cultivation should be considered as obstacles for the landscape in fulfilling its functions.

For conservation investments to be efficient, an agrobiodiversity conservation initiative should not aim to intervene in an area with too high or too low a level of threat or too little an opportunity to address those threats. The 'optimal level of threat' for intervention is hard to determine, and probably differs between conservation agencies, but in the absence of threat the opportunity costs for 'no intervention' are negligible and if the threat is not matched by opportunities to counteract it, outside efforts will appear to be a waste of time and resources.

The application of the tool in Bungo, Indonesia and North Thailand. Both sites have potential for an agrobiodiversity conservation initiative. The service at both sites to be advocated is the potential role as corridors to connect national parks. Some concerns about future challenges to engage in developing rewards for biodiversity conservation were mentioned. At the Bungo site, intermediaries who can find interested parties (buyers) to make an initial investment as part of developing a reward for environmental service are required. In the Northern Thailand, lack of trust is a bottleneck.

A further implication of the 'optimal threat' issue is that gender-based differences in appreciation of local resources can shift the 'perceived threat': in some situations this may lead to much-needed trust that local beneficiaries of environmental services that were not initially heard will help secure the continuation of the service, once sufficiently empowered and alongside an external rewards system. In other cases, however, where the threat was already below the level that triggers the maximum willingness to engage, a stronger local appreciation of the service will lead to the expectation that the service can be provided free of charge.

\subsubsection{Value, benefits and beneficiaries of ES}

CRES schemes need to be realistic in terms of assumptions about economic value: 1) that ecosystems with low levels of exploitation yield valuable environmental services, 2) that financial and economic incentives are key drivers of land and resource use in natural ecosystems that reduce the provision of ES, and 3) that sufficient value can be captured from the beneficiaries of environmental services to adequately pay land managers to either protect and manage land and resources in a way that will continue to generate environmental services and prevent further degradation of environment in a compensation scheme. Current practice in designing CRES schemes, however, tends to cut corners on one or more of these assumptions. There is an emerging concern that in many cases both the economic benefits and costs of environmental conservation remain substantially under-valued, and significantly under-captured. A major challenge remains to ensure that CRES schemes are based on 
understanding of the economic costs and benefits for the various stakeholders involved in the maintenance and provision of environmental services. From the perspective of the beneficiaries and/or buyers of environmental services, it is often too readily assumed (Johnson et al. 2001) that 1) environmental services have an economic value in the first place, 2) that ecosystem conservation through ES Reward schemes is a cost-effective way of generating particular environmental services, and 3) that the beneficiaries/users of environmental services are both willing and able to pay for them. Economic valuation techniques (Table 7; Emerton et al. 2004) usually depend on some kind of production function or cost-based relationship between the status of a particular ecosystem and changes in the provision of environmental services. Applicability of the various techniques is still under debate (Zhang and Li 2005; Brown et al. 2005).

Table 7. Five classes of commonly used economic valuation methods that can be used in emergent CRES schemes (Emerton and Bos 2004)

\begin{tabular}{|c|c|c|}
\hline Approach & Explanation & Applicability \\
\hline $\begin{array}{l}\text { Market } \\
\text { prices }\end{array}$ & $\begin{array}{l}\text { This approach looks at the market price of ecosystem } \\
\text { goods and services }\end{array}$ & $\begin{array}{l}\text { This assumes that there is a } \\
\text { market }\end{array}$ \\
\hline $\begin{array}{l}\text { Production } \\
\text { function } \\
\text { approaches }\end{array}$ & $\begin{array}{l}\text { These approaches, including effect on production, attempt } \\
\text { to relate changes in the output of a marketed good or } \\
\text { service to a measurable change in the quality of quantity } \\
\text { of ecosystem goods and services by establishing a } \\
\text { biophysical or dose-response relationship between } \\
\text { ecosystem quality, the provision of particular services, } \\
\text { and related production }\end{array}$ & $\begin{array}{l}\text { Dose-response relationships } \\
\text { will depend on many co- } \\
\text { variates and show 'hysteresis' } \\
\text { effects where recovery from } \\
\text { loss is slow }\end{array}$ \\
\hline $\begin{array}{l}\text { Surrogate } \\
\text { market } \\
\text { approaches }\end{array}$ & $\begin{array}{l}\text { These approaches, including travel costs and hedonic pricing, } \\
\text { look at the ways in which the value of ecosystem goods } \\
\text { and services are reflected indirectly in people's expendi- } \\
\text { tures, or in prices of other market goods and services }\end{array}$ & $\begin{array}{l}\text { This may apply well to the } \\
\text { landscape beauty and } \\
\text { tourism case, less for other } \\
\text { types of ES }\end{array}$ \\
\hline $\begin{array}{l}\text { Cost-based } \\
\text { approaches }\end{array}$ & $\begin{array}{l}\text { These approaches, including replacement costs, mitigative or } \\
\text { avertive expenditures and damage costs avoided, look at the } \\
\text { market trade-offs or costs avoided of maintaining } \\
\text { ecosystems for their goods and services. }\end{array}$ & $\begin{array}{l}\text { This can provide a realistic } \\
\text { evaluation of the options the } \\
\text { potential 'buyer' has, but } \\
\text { assumes there are fair com- } \\
\text { parator options }\end{array}$ \\
\hline $\begin{array}{l}\text { Stated } \\
\text { preference } \\
\text { approaches }\end{array}$ & $\begin{array}{l}\text { Rather than looking at the way in which people reveal } \\
\text { their preferences for ecosystem goods and services } \\
\text { through market production and consumption, these } \\
\text { approaches ask consumers to state their preference } \\
\text { directly. The most well-known technique is contingent } \\
\text { valuation, while less commonly-used stated preference } \\
\text { valuation methods include conjoint analysis and choice } \\
\text { experiments. }\end{array}$ & $\begin{array}{l}\text { This can help to suggest the } \\
\text { preferred forms of contracts } \\
\text { once the need for such is } \\
\text { established; it can support } \\
\text { the negotiation process }\end{array}$ \\
\hline
\end{tabular}

\subsubsection{Cost and cost-bearer of ES provision}

From the perspective of the providers of environmental services or the recipients of reward or compensation, as well as for intermediaries or brokers, CRES schemes assume both that financial and economic compensation mechanisms are an acceptable and adequate incentive for land and resource users to manage ecosystems in a particular way (i.e. so as to generate environmental services), and that introducing and running some form of compensation mechanism can be sustained in financial and economic terms.

Just as economists have traditionally had a very narrow concept of environmental benefits, so the costs of environmental conservation have tended to be underestimated. Traditional conservation approaches, and financing, have tended to focus on the operational 
costs of managing an ecosystem - primarily the expenditures made on capital, infrastructure, equipment, policing and operations. Yet the indirect or opportunity costs of managing ecosystems to provide environmental services are in many cases far higher, and more wideranging, than these direct costs. For example, the opportunity costs of alternative land and resource uses foregone due to the creation of Khao Yai National Park in Thailand are estimated at some 27 million Baht per year (about US\$675,000), or almost nine times the direct management costs (Dixon and Sherman 1990). Opportunity costs primarily include the value of alternative land and resource uses which are diminished or foregone as a result of conservation, but many also have other elements such as costs associated with crop depredation by wild animals.

Valuation provides a mechanism for quantifying the nature and magnitude of environmental service provision costs, and identifying the groups who bear them. Here, it is particularly critical that valuation encompasses distributional and equity concerns. The human communities who live in important natural ecosystems in developing countries, especially poorer and more vulnerable groups, typically rely heavily on ecosystems goods and services as key inputs into their livelihoods. Any management option that considers changing land use regimes, restricting the use of these goods and services or preventing the uptake of other income-generating opportunities will impose tremendous - and often untenable - livelihood costs on these households (Emerton et al. 2004).

A third set of costs relates to the actual implementation of ES Reward schemes. ES Reward schemes are not cost-free to operate: they require time, expertise and management, and incur a variety of transaction costs for buyers and sellers as well as for the intermediary or broker who manages the operation of the scheme. Although transactions costs can be substantial, and need to be factored into calculations, it is relatively rare for these values to be identified and understood when ES Reward schemes are designed (Tognetti et al. 2003). Even where they have been considered, transactions costs are often under-estimated when ES Reward schemes are designed. In the case of payment for carbon sequestration services, for example, it has been argued that there are considerable transaction costs, including those incurred in negotiation of contracts, carbon monitoring, carbon-credit commercialisation, and technical assistance for the implantation of technical operations (May et al. 2004).

The direct costs of ecosystem conservation and the transaction costs of ES Reward schemes can be estimated relatively easily, usually from the budgets of whichever authority is mandated to manage a particular ecosystem, or the business plan or project plan for CRES activities. Valuation of the opportunity costs of environmental service provision however typically requires a larger body of data and a wider coverage, as well as the utilization of more complex methods (such as effects on production) in order to encompass the wide range of groups and costs to whom these costs are incurred.

Having identified the providers of environmental services, and valued the level and type of costs incurred to them, additional work is still required to assess the conditions under which providers can be transformed into sellers of environmental services (as is required under voluntary CRES). Although a minimum requirement for RES, it is not self-evident that when the direct and indirect costs of ecosystem conservation are covered that land and resource users will be willing to conserve ecosystems for the provision of environmental services. Both the level and the type of compensation that providers are willing to accept must be determined. Valuing the willingness of ecosystem service providers to accept compensation relies in most cases on some form of contingent valuation or other stated preference technique. Here, distributional elements are again of particular importance, in terms of what levels and types of costs are being incurred by different groups of users, and what variation exists in the levels and types of compensation (if any) that these different groups are willing to accept. 
The use of valuation to investigate demand-side aspects of ES Reward schemes does not however end with establishing the potential and actual value of environmental services. Even where potentially valuable environmental services can be demonstrated to occur, it is not self-evident that users or beneficiaries would be either willing or able to pay for the services they receive. Everything up to this point is academic unless there are willing buyers of environmental services (Johnson et al. op. cit). It is not always the case in practice that beneficiaries are willing to pay for ecosystem service values received. For example, a study in Costa Rica's Rio Chiquito catchment area of the Arenal watershed found that neither the market by itself, nor compensatory payments offered by the government for reforestation, provided an incentive to reforest steep slopes used for cattle ranching and agriculture (Aylward and Echeverria 2001). It is therefore necessary to ascertain whether the identified beneficiaries or users of environmental services can be transformed into buyers. Here, too, valuation can provide important information for the negotiation and design of CRES. There is now a relatively large literature which deals with determining beneficiaries' willingness to pay for environmental services, and which relies in most cases on some form of contingent valuation or other stated preference technique. See, for example, a discussion of farmers' willingness to pay for watershed services in Indonesia in Pattanayak and Kramer (2001) and local residents' willingness to pay for coastal wetland preservation in South Korea (Pyo 2002).

\subsubsection{Gap analysis: what is the potential for capturing environmental service values as compensation?}

Having ascertained the value of the benefits and costs associated with environmental service provision, their distribution, and the potential willingness of buyers and sellers to provide and receive compensation, a key question is whether there exists (or can exist) the potential to set in place ES Reward schemes mechanisms. Here the actual / potential effectiveness of ES Reward schemes again depends on investigating and testing a number of assumptions about economic costs and benefits: that sufficient values can be captured from the beneficiaries of environmental services to cover the full costs of implementing CRES, and to motivate providers to manage land and resources in a way that will continue to generate environmental services.

The quantification and comparison of the costs and the benefits of environmental service provision for different stakeholders is necessary to do this. Various value-based criteria guide the extent to which ES Reward schemes are likely to be realistic, effective, equitable and sustainable. A minimum level of ES Reward schemes requires that both the direct and indirect costs of environmental service provision are covered (Echavarria et al. op. cit.), the real value of the environmental service provided and used is reflected, and that transaction costs are less than the difference between maximum buyer and minimum seller price. In order to establish that ES Reward schemes will meet these criteria, a simple costbenefit analysis can be used to highlight where significant gaps in costs over benefits occur for service providers and there is a need for compensation, where significant gaps in benefits over costs occur for users which there is an opportunity for capture as payment.

However, although fulfilling the above criteria is a necessary condition for ES Reward schemes to be effective, they may not by themselves be sufficient. In addition to the potential for ES Reward schemes to be captured and allocated, beneficiaries have to be willing and able to be transformed into buyers by paying for the environmental services they receive, and providers must be willing and able to be transformed into sellers by accepting compensation for the environmental services they generate. Basically, potential sellers have to be willing to offer environmental service at prices that buyers are willing to pay (Johnson et al. op. cit.). As described above, a basic understanding and analysis of both willingness to pay and willingness to accept compensation acts as a final check on the reality of CRES. 


\section{Box 4. Fair compensation for inflicted environmental damage?}

Prevention is usually cheaper than cure - but that doesn't mean that companies can't cut cost by not applying the prescribed preventive measures.

On May 292006 hot mud started to flow in a densely populated part of East Java (Indonesia) in Sidoarjo regency. Five sources of leakages poured out huge volume of the mud to the ground. A gas drilling company, PT Lapindo Brantas Inc. was suspected to have been negligent in their drilling procedures; initially they claimed that the mud did not come from its well but from a source 150 meters from the company's well. They argued that the appearance of hot mud coincided with a 2.5 Modified Mecarlli Intensity scale earthquake nearby. According to experts from the Meteorology and Geophysics Agency, the mudflow was not caused by the earthquake preceding the incident.

On June 20, the vice-president of Indonesia stated that "Lapindo must bear responsibility, socially and materially, for the victims of the mudflood". The vice president visited the refugee camp accompanied by a number of ministers. As the company is owned by the family of the Minister of Human Welfare, the slow response has become an issue of public concern. Based on the law, oil and gas resources belonged to the state but their development was being done by contractors. "The occupational accident at Lapindo`s gas exploration well and its impact on the people will be settled jointly by the government and Lapindo. But matters relating to compensations will be settled and borne by Lapindo", according to the vice-president.

On June 20, Lapindo Brantas represented by its chief executive officer handed over a first-stage compensation of Rp. 300,000 (US\$32) monthly pay to mudflood victims. "This is only the first phase of compensation. All losses suffered by villagers will be covered later by the company," according to the company. The number of refugees at the Pasar Baru camp was recorded at 776 families or 3,092 people. They came from the villages of Jatirejo, Siring, Renokenongo and Kedung Bendo.

The mud kept flowing - and by 12 August it was clear that effects from the mudflow would keep thousands of displaced residents from ever returning to their homes. The mudflow also caused some small-middle factories to stop their operations. Fifteen factories were affected and more than 120 hectares of village paddy fields in five villages were inundated. Most of the residents, who are farmers, have lost their livelihoods and other villages nearby are being threatened by water supplies contaminated by the mud. Besides their physical suffers caused by the sulphurous fumes produced by the mud, most of the refugees were under mental stress due to the lost of their property and fear of being permanently laid off by their companies.

The provincial turnpike was covered with $60 \mathrm{~cm}$ of mud. It was temporarily closed cutting the main traffic flow from the capital city to its satellite areas and from agricultural and factory producers to the port. The drilling company itself estimated earlier it had sustained losses of around Rp.1 billion (US\$ 108,695). A number of producers forcedly cut their costs by reducing their workers' pay from Rp. 500,000 to Rp. 300,000 per month. The livelihood of 1,500 workers from 350 bags and luggage producers were put on stakes.

From the environmental perspective, the mudflow was found to have an above-threshold level of phenol and a very high salinity. It contaminated the communities' domestic water wells. The gas from the mudflows also polluted the air and increased the air concentration of $\mathrm{NH}_{3}$ and $\mathrm{SO}_{2}$. The initial conclusion was that the 2.3 million cubic-meter hot mudflow was dangerous and poisonous although the level of its toxicity was still categorized as low. Furthermore, ecosystem would need decades to recover from this accident. Police investigation meanwhile established that the company did not install a pre-scribed drill casing at 8500 feet underground. Because of this, the well did not resist pressures and finally mud started to flow - effectively unstoppable. The operator itself would suffer more than US\$6 million as the loss of their failure to operate a gas drilling well.

In terms of 'fair compensation' it is a challenge to define how far down the causation-chain one has to go. The company staff who lost their job, the people displaced from farms and villages surely are to be compensated. The people who lost jobs because other companies lost business opportunities, will likely have to carry the burden themselves. The fishermen in the river and the coastal area where the mud will be deposited will have to adjust to the reality that the river and marine ecosystem area affected. Despite the unrest disputes of the mudflows, the villagers have proved their creativity for survival. They dried the mud and used it as basic commodities of bricks and tile-roofs.

Six months after the event the Lapindo company bought all the land of the four affected villages at the going market rate for rice paddies and settled areas, as their final bid in the compensation issue.

Sources."Muddy East Java Turnpike Partially Back in Operation" and "Mudflow Refugees Counting the Costs of Drilling Disaster" (The Jakarta Post, July 7, 2006); "Menunggu Akhir Lumpur Sidoarjo" and "Memandang Tumnur Bukan Sehaoai Rencana" (Komnas Iulv 17 2007) 
The use of valuation does not end with the establishment of a ES Reward scheme. It is also necessary to monitor and track economic costs and benefits over the course of implementing CRES. It is only once ES Reward schemes are operational that their ultimate effectiveness and impact can be gauged, including the extent to which they have met particular social equity or pro-poor goals (Miranda et al. 2003). In addition, the ongoing effectiveness of ES Reward schemes depends on the criteria which have been described in the paragraphs continuing to be fulfilled, meaning that these indicators of value need to be regularly reviewed and rechecked over the lifetime of a ES Reward scheme. (Landell-Mills and Porras 2001). Various forces and conditions may change both the benefits and the costs associated with ES Reward schemes and environmental service provision, which may warrant redesigning the level, type or distribution of payments and compensation.

\subsubsection{Sub-criteria and indicators}

Based on these considerations, we propose 4 sub-criteria for criterion I, and a number of possible indicators that can be used for various stages of CRES development (Table 8).

Table 8. Sub-criteria and indicators for criterion I. Realistic (Effectively mitigating, reducing or avoiding threats to ES for all parties involved); the large (bolded) asterix indicates the stage (within a row) where the criterion is most relevant

\begin{tabular}{|c|c|c|c|c|c|}
\hline Sub-criteria & Indicators & $\begin{array}{l}\text { Sco- } \\
\text { ping }\end{array}$ & $\begin{array}{l}\text { Stake- } \\
\text { holder } \\
\text { analysis } \\
\& \text { Nego- } \\
\text { tiating }\end{array}$ & $\begin{array}{l}\text { Im- } \\
\text { ple- } \\
\text { men- } \\
\text { ting }\end{array}$ & $\begin{array}{l}\text { Evalu- } \\
\text { ating }\end{array}$ \\
\hline \multirow{4}{*}{$\begin{array}{l}\text { 1. A broadly shared perception } \\
\text { of cause-effect relations links } \\
\text { threats to ES or to the } \\
\text { ecosystem that provides ES, to } \\
\text { potential activities to reduce } \\
\text { or avoid these threats by } \\
\text { identifiable actors at a relevant } \\
\text { temporal and spatial scale }\end{array}$} & $\begin{array}{l}\text { Perception gaps between relevant } \\
\text { stakeholders on cause - effect } \\
\text { relations f land use effects on ES }\end{array}$ & * & & & \\
\hline & $\begin{array}{l}\text { Spatial scaling relations of the ES and } \\
\text { the effects of threats (non-linearities, } \\
\text { thresholds) }\end{array}$ & $*$ & * & & $*$ \\
\hline & $\begin{array}{l}\text { Temporal relations (limits to } \\
\text { recovery and reversibility, thresholds) }\end{array}$ & $*$ & $*$ & & $*$ \\
\hline & $\begin{array}{l}\text { Specificity of actor roles (gender } \\
\text { specific and incl. the rural poor) in } \\
\text { avoidance/ reduction of threats and } \\
\text { influencing conservation uses }\end{array}$ & * & & & \\
\hline \multirow{5}{*}{$\begin{array}{l}\text { 2. The value to ES-bene- } \\
\text { ficiaries of reduction or } \\
\text { avoidance of the threats, } \\
\text { relative to alternative ways to } \\
\text { meet their needs, is } \\
\text { substantive (within the } \\
\text { context of the key actors) }\end{array}$} & $\begin{array}{l}\text { Baseline of ecosystem condition } \\
\text { and/or sustainable ES levels }\end{array}$ & * & & & \\
\hline & $\begin{array}{l}\text { Perceived shortage in ES as basis for } \\
\text { interest by identifiable outside } \\
\text { stakeholders }\end{array}$ & * & & & \\
\hline & $\begin{array}{l}\text { Willingness to pay (corrected for } \\
\text { 'ability to pay') for continuation/ } \\
\text { restoration of the ES }\end{array}$ & $*$ & $*$ & & $*$ \\
\hline & $\begin{array}{l}\text { Economic value of the ES (whether } \\
\text { potential or actually captured) as } \\
\text { basis for political decisions on public } \\
\text { investment in specific ES }\end{array}$ & & * & & \\
\hline & $\begin{array}{l}\text { Leakage: negative effects on ES } \\
\text { outside of the 'target' area, that are } \\
\text { (or can be) causally linked to interact }\end{array}$ & $*$ & & & $*$ \\
\hline
\end{tabular}




\begin{tabular}{|c|c|c|c|c|c|}
\hline Sub-criteria & Indicators & $\begin{array}{l}\text { Sco- } \\
\text { ping }\end{array}$ & $\begin{array}{l}\text { Stake- } \\
\text { holder } \\
\text { analysis } \\
\text { \& Nego- } \\
\text { tiating }\end{array}$ & $\begin{array}{l}\text { Im- } \\
\text { ple- } \\
\text { men- } \\
\text { ting }\end{array}$ & $\begin{array}{l}\text { Evalu- } \\
\text { ating }\end{array}$ \\
\hline \multirow{6}{*}{$\begin{array}{l}\text { 3. There are opportunity } \\
\text { costs and/or resource access } \\
\text { constraints for the potential } \\
\text { 'ES providers' that can be off- } \\
\text { set or overcome without major } \\
\text { negative 'external effects' } \\
\text { (leakage) }\end{array}$} & $\begin{array}{l}\text { Baselines of minimum acceptable } \\
\text { ES-affecting behaviour are clear }\end{array}$ & $*$ & $*$ & & \\
\hline & $\begin{array}{l}\text { Opportunity costs of ES-friendly } \\
\text { land use types with respect to the } \\
\text { current baseline and to minimum } \\
\text { acceptable ES-affecting behaviour } \\
\text { are clear and show a significant gap } \\
\text { in costs over benefits }\end{array}$ & & * & & \\
\hline & $\begin{array}{l}\text { Willingness to accept studies have } \\
\text { clarified which financial and } \\
\text { economic incentives are needed to } \\
\text { modify key drivers of land and } \\
\text { resource use and potential buyers are } \\
\text { aware of this level }\end{array}$ & $*$ & $*$ & & \\
\hline & $\begin{array}{l}\text { Sufficient values can be captured on } \\
\text { a long-term basis from the } \\
\text { beneficiaries of environmental } \\
\text { services to adequately motivate } \\
\text { providers to continue to manage land } \\
\text { and resources in a way that will } \\
\text { continue to generate environmental } \\
\text { services. }\end{array}$ & $*$ & $*$ & & \\
\hline & $\begin{array}{l}\text { Compensation or reward reflect (at } \\
\text { least) the real opportunity costs of } \\
\text { providing for the ES }\end{array}$ & $*$ & $*$ & & \\
\hline & $\begin{array}{l}\text { Additionality of the supply of the } \\
\text { target environmental service relative } \\
\text { to an appropriate (dynamic) baseline }\end{array}$ & $*$ & * & & $*$ \\
\hline \multirow{2}{*}{$\begin{array}{l}\text { 4. The threat to the ES and its } \\
\text { reduction (or avoidance) by ES } \\
\text { providers can be assessed and } \\
\text { monitored in a transparent } \\
\text { way, as a basis for conditional } \\
\text { incentives }\end{array}$} & $\begin{array}{l}\text { Transaction cost is kept low through } \\
\text { efficient intermediaries and is } \\
\text { explicitly recognized to ensure } \\
\text { sustainability. }\end{array}$ & & $*$ & & \\
\hline & $\begin{array}{l}\text { The sellers are well-informed that the } \\
\text { buyers satisfied }\end{array}$ & & & $*$ & \\
\hline
\end{tabular}

\subsection{Voluntary: adaptive, efficient}

The key distinction between CRES and purely regulatory (imposed) solutions to ES issues, is that both buyers and sellers voluntarily agree on the nature and level of 'deliverables' in reward agreements. The 'bargaining power' of both buyers and sellers can increase with insights into each others strategies.

There are substantive differences in the scaling relationships of the different ES that influence the scale of decision-making that has to be influenced to protect or recover ES (Figure 12). Services such as carbon sequestration are approximately proportional to the fraction of area involved, and thus have 'simple' scaling relationships. Some environmental service functions only exist if everybody complies: e.g. ground or surface water quality can be compromised by a few point sources of pollutants, and a watershed will only generate clean 
water if all actors follow restrictions. Other functions, such as the maintenance of species richness or adequate filter functions for overland flows, can in fact be achieved at nearmaximum levels on only part of the total area of a catchment. This scaling relationship of the ES influences the degree of 'collective action' that is needed to generate the ES at a level that is worthy of award and the relevance of expressing awards on a per unit area basis.

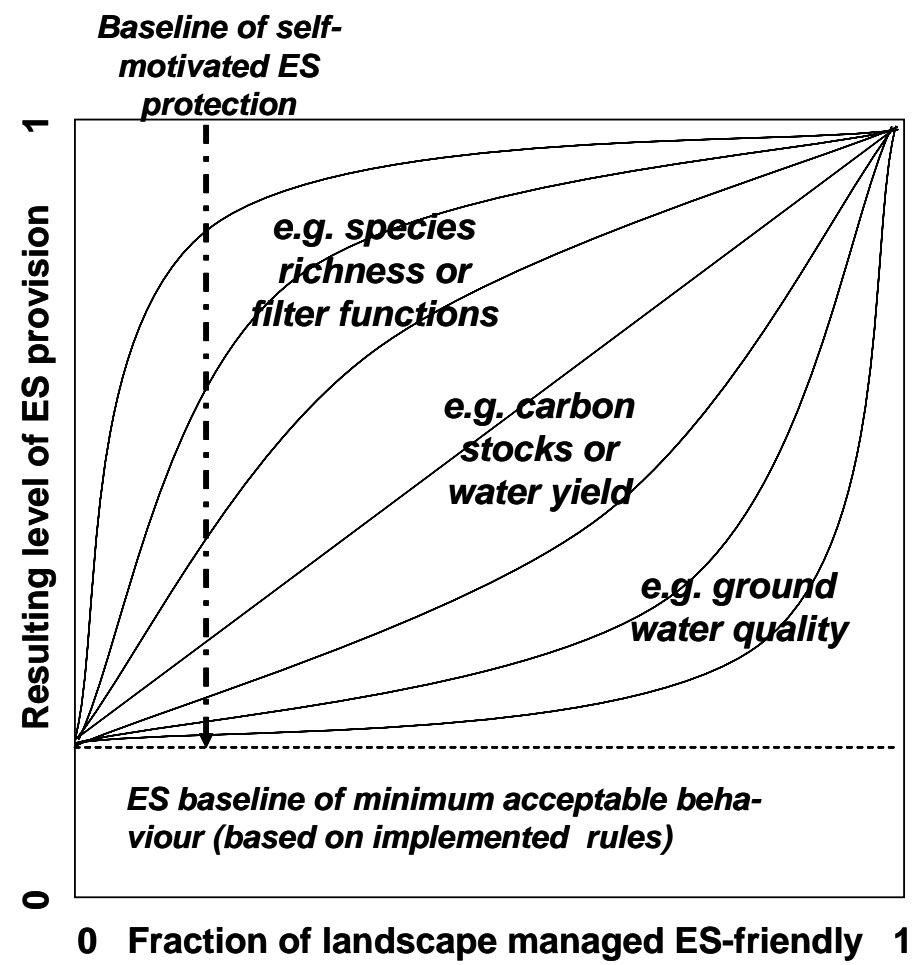

Figure 12. Schematic scaling relationship between the landscape level of ES production and the fraction of the landscape that is managed in an ES-friendly way (modified from van Noordwijk et al., 2004)

Transaction costs tend to have strong economies of scale and can be brought back to acceptable levels if a sufficient number of smallholders agree to act collectively, but intragroup costs will dominate once an optimal group size is reached, unless an effective layered hierarchy emerges (see discussion of Figure 9). These group decisions restrict the individual freedom of the members, and are thus at risk of defection and free riding.

Collective action and interactions that involve common property rights have a typical problem of representation, where local elites can capture private benefits by selling off community rights, claiming to be legitimate representatives. Based on substantial, and often acrimonious debate, guidelines have been developed to assess the degree of 'free and prior informed consent' for individual members of local communities involved in transactions of land rights. The Roundtable on Sustainable Oil Palm has recently pioneered the development of criteria and indicators in this regard, that can be of use for ES-related transactions of land use rights and voluntary acceptance of restrictions on land use and land cover change. Early attempts to acquire land for carbon sequestration projects has, for example, lead to serious concerns over loss of autonomy and rights, similar to conversion for the plantation sector. The only way for the rural poor to respond to such cases in the past has been the use of fire as a weapon (Suyanto et al. 2004; Dennis et al. 2005). An important sub-criterion for voluntary transactions is the clarity on exit strategies from contracts for either of the contractants and for fair procedures for conflict resolution. 


\section{Box 5. Case study in application of scale / RUPES Sumber Jaya: individual coffee plot management versus subcatchment level cooperation for low sediment loads}

Sumberjaya is a subdistrict in the mountain range (Bukit Barisan). That mountain range spans along the west coast of Sumatra and forms the upper watersheds of all major rivers on the island. The 55,000-ha subdistrict almost coincides with the Way Besai upper watershed. About $40 \%$ of the subdistrict is classified as 'protected forest' and $10 \%$, as a national park. Nevertheless, forest cover has declined from $60 \%$ in 1970 to $12 \%$ in 2000 , leaving vast areas of deforested hillsides bare. Simultaneously, coffee farms have increased tremendously.

Land tenure for forest land stewardship ( $\mathrm{HKm})$ is the main reward mechanism proposed for watershed protection through better land protection and tree planting in farmers' coffee agroforestry system. The second scheme being tested in the Sumberjaya watershed is the establishment of an environmental service transaction between the local hydroelectric power company and the upstream communities.

Two approaches have been undertaken for the second scheme in reducing the sedimentation level of the Way Besai river. The first one is to engage the private owners of coffee garden in a land conservation program. The land conservation program involves farmers at two sub-watersheds in applying sediment pits combined with ridging and natural vegetative strips on their private lands. A reverse auction was conducted to capture the opportunity cost of farmers in joining such programs. This method was also effective in filtering different enabling land conditions for farmers in applying the contracted offer and in allocating the contracts to the 'winning' farmers. The argument in using this approach is that the environmental outcomes cannot be increased in short term. Budget limitation of the buyer will be distributed unevenly only within 'winning' farmers - which can result on 'patchy' land management in a subwatershed.

The second one is to involve the community within a sub-watershed in decreasing the sediment loads. The detailed hydrological research from ICRAF played an important role in recognizing the sedimentation 'hot-spot'. Combined with local people's knowledge on source of erosion, these people would work together in 'fixing' the hot-spot. The activities varied from compacting soil for small roads and trails, building small dams to trap sediment in the river, and putting wooden-blocks along the river ridges to avoid land slides. This approach is expected to reduce sediment levels in the stream within the time frame of a year, without prescribing the solution. It builds on and supports local creativity.

Table 9. Sub-criteria (numbering continued from Table 8) and indicators for criterion II.

Voluntary: engagement involves choice rather than being the object of regulation; the large

(bolded) asterix indicates the stage (within a row) where the criterion is most relevant

\begin{tabular}{|l|l|r|r|r|r|}
\hline Sub-criteria & Indicators & $\begin{array}{l}\text { Sco- } \\
\text { ping }\end{array}$ & $\begin{array}{l}\text { Nego- } \\
\text { tiating }\end{array}$ & $\begin{array}{l}\text { Imple- } \\
\text { menting }\end{array}$ & $\begin{array}{l}\text { Evalu- } \\
\text { ating }\end{array}$ \\
\hline $\begin{array}{l}\text { 5. Legitimacy at indi- } \\
\text { vidual level: representa- } \\
\text { tion is subject to checks } \\
\text { and balances }\end{array}$ & $\begin{array}{l}\text { 'Free and prior informed consent' } \\
\text { (FPIC) of community members is } \\
\text { secured where 'community scale' } \\
\text { contracts and decisions are } \\
\text { involved }\end{array}$ & $\boldsymbol{*}$ & $\boldsymbol{*}$ & & \\
\hline
\end{tabular}




\begin{tabular}{|c|c|c|c|c|c|}
\hline \multirow[t]{2}{*}{$\begin{array}{l}\text { 6. Effective voice of all } \\
\text { stakeholders is secured } \\
\text { through negotiation } \\
\text { support }\end{array}$} & $\begin{array}{l}\text { Where voluntary restrictions on } \\
\text { legal, but ES-threatening activities } \\
\text { are accepted, contract partners } \\
\text { have had access to negotiation } \\
\text { support and are aware of their } \\
\text { 'bargaining power' }\end{array}$ & $*$ & * & & \\
\hline & $\begin{array}{l}\text { Transparency of information } \\
\text { across literacy, gender and wealth } \\
\text { strata }\end{array}$ & & * & & \\
\hline \multirow[t]{3}{*}{$\begin{array}{l}\text { 7. Adaptiveness of the } \\
\text { mechanism includes a } \\
\text { time frame for review and } \\
\text { exit strategy }\end{array}$} & $\begin{array}{l}\text { Responsibilities are balanced by } \\
\text { rights in an institutional } \\
\text { framework with provisions for } \\
\text { arbitration and conflict resolution }\end{array}$ & & $*$ & $*$ & \\
\hline & $\begin{array}{l}\text { Built-in commitment to impact } \\
\text { studies and learning from } \\
\text { experience }\end{array}$ & & * & & * \\
\hline & $\begin{array}{l}\text { Exit strategy (risk, length of } \\
\text { contract) }\end{array}$ & $*$ & & * & \\
\hline
\end{tabular}

\subsection{Conditional: effective, transparent}

The basic logic of any market transaction is that 'delivery' and 'payment' are logically related, even though a book keeping of debit and credit can de-couple the two temporarily. 'Market failure' in the case of environmental services is, among other factors, linked to the fact that 'delivery' of such services is not easily measurable and transparently linked to actions of sellers, while threats to temporarily withhold the service in case of non-payment are hardly implementable as means of exerting pressure (and tend to be not easily reversible if implemented). Many CRES mechanisms thus rely on perceptions of services (as stated in section 3.2) and good faith between the contracting partners.

Figure 10 introduced five levels at which conditionality of CRES can be envisaged, with the likely advantage of using multiple levels in any particular scheme and the opportunities for the gradual development of trust (level V) over time. At the first level, the contractual relationship is based on the establishment of a set of criteria and indicator on the actual supply of ES. Examples can be payments per $\mathrm{m}^{3}$ of clean water derived from a watershed or the amount of electricity produced on a hydro-electric scheme. 'Pay what you get' (and no more) is attractive for the buyers. However, there may be substantial costs and complications involved in the measurement, as baselines are debatable and the level of the ES is often strongly influenced by external factors, such as the year-to-year variation in rainfall, the occurrence of 'extreme events' (including hurricanes, earthquakes or tsunami's), and processes of global change (climate change, sea level rise, exotic invasive species) that have a potentially strong effect on the ES level. Especially where the supposed ES providers are poor and have little capacity to absorb risk, it may not be fair to (fully) implement conditionality at level I.

At the second level the actual condition of the agro-ecosystem is taken as the basis for conditionality. A stock-based approach has potential advantages over a flow-based accounting of ES, as it is easier to observe. Remote sensing techniques continue to improve in spatial and temporal resolution, while automated interpretation and calibration procedures have been developed. However, the costs of such monitoring are not yet negligible, imagery tends to be incomplete due to e.g. cloud cover (especially in the humid tropics...) and the procedures are not error-free. Classification errors of $10 \%$ in pixel-level analysis of remote sensing images are deemed satisfactory - but are problematic if major CRES implementation decisions are linked to pixel-level data. 
At the third level, 'rewards' will be given if the local actors 'make an effort, and follow agreed actions. An example of this would be maintaining good land management that meets specified restrictions or protects a piece of land that is ecologically sensitive. Payment for the time spent on agreed 'rehabilitation' efforts, regardless of the final impact on the return of ES may make sense for risk-averse poor actors, but grades into regular public investment projects paid at or below the local minimum wage rate. Yet, it forms a 'fall back' criterion of opportunity costs of labour, if an effective and efficient monitoring system can be found. A link to level II criteria may be useful, e.g. where the number of trees planted remains visible proof of planting effort. From the buyers' perspective, conditionality based on effort, however, is not very attractive, as it requires substantial supervision costs. For the sellers it can easily lead to micro-management and loss of freedom to innovate and enhance efficiency (enhanced efficiency can be easily perceived as 'fraud' in effort-based accounting...)

The fourth level of conditionality is not concerned with the details of what land users do on a day-to-day basis, but is focused on overall management approaches. Adaptive comanagement has become a popular phrase in management of forest resources, relying on (and potentially strengthening) community-scale decision and control processes. A focus on the management level is based on (and constrained by) the communities' right to regulate internal use patterns and transform the resource by making improvement, providing linkages to risksharing and conflict resolution (Carlsson and Berkes 2005).

As existing ES issues may well be linked to perverse incentives in the national or local management level, a focus at this scale is relevant. Stop 'PUPES' (punishing upland poor and the environment) before 'RUPES' or 'To Not Punish is To Reward' introduced by Gouyon (2003) is relevant at this stage. For example, lifting policies that promote environmentally harmful practices or/and discriminate against the poorer or smaller farmers. Harmonizing of perceptions on managing the environment to achieve 'win-win solution' is acknowledged by the external stakeholder, who will 'pay for the way they (the local actors) decide on what to do or what not to do.

At the fifth level the conditionality takes a further step back and is expressed in terms of trust. At the start of the Integrated Conservation and Development Programs (ICDP) there was an element of (in hindsight naïve) trust that indigenous people would manage all natural resources sustainably if left to their own devices. Conditionality based on trust obviously requires mechanisms for evaluating whether or not past trust has been justified, but it may form a basis for a long-term more equitable relationship. Ferraro and Simpson (2005) referred the ICDP as indirect intervention in meeting the environment and development goals that are likely to require a sustained flow of funds over time to maintain conservation outcomes over long-term. Meaning, support and trust of mutually agreed objectives and criteria become the main basis of this practice.

Axelrod (1997) took the classical cooperation/defection problem (Prisoner's Dilemma) to agent-based modelling studies of coping strategies for errors in perception or implementation, emergence of norms and development of a shared culture between new political actors and regions. While the simple 'tit for tat' strategy (start with cooperation but immediately respond to defection) is superior to less cooperative strategies, it is open to errors. In environments with at least some 'random noise' a 'tit for two tats' is superior, as it accommodates some 'erroneous interpretation', but even that may loose from more cooperative strategies. In a very cooperative world, however, rogue defectors have a chance to exploit the soft side of society. Application of these concepts to the dynamics of 'conditionality' of CRES may help to understand the significance of 'errors of perception'. 


\section{Box 6. Agri-environment schemes do not effectively protect biodiversity in Dutch agricultural landscapes - based on Kleijn et al., 2001}

Roughly $20 \%$ of the European Union's farmland is under some form of agri-environment scheme to counteract the negative impacts of modern agriculture on the environment. The associated costs represent about 4\% (1.7 billion euros) of the European Union's total expenditure on the Common Agricultural Policy and are expected to rise to $10 \%$ in the near future. Two instruments have been part of the EU's common agricultural policy for a long time. A specific percentage of the obligatory set-aside is supposed to be assigned to nature conservation tasks. To gain maximal ecological benefit from these spots, specific conservation measures may be necessary as well. Therefore, the compulsory module of set-aside is complemented by voluntary agri-environmental programmes that compensate farmers for costs arising from specific management activities defined by nature conservation demands (Berger et al., 2006).

Although agri-environment schemes had been implemented in various countries for well over a decade, until 2001 no reliable, sufficiently replicated studies had been performed to test whether such measures have the presumed positive effects on biodiversity. Kleijn et al. (2001) presented the results of a study evaluating the contribution of agri-environment schemes to the protection of biodiversity in intensively used Dutch agricultural landscapes. They surveyed plants, birds, hoverflies and bees on 78 paired fields that either had agri-environment schemes in the form of management agreements or were managed conventionally. Their results were as revealing as statements that the emperor doesn't have clothes. Management agreements were not effective in protecting the species richness of the investigated species groups: no positive effects on plant and bird species diversity were found. The four most common wader species were observed even less frequently on fields with management agreements. By contrast, hoverflies and bees (which were not the primary target of the agreements) showed modest increases in species richness on fields with management agreements. Their results indicated that there is a pressing need for a scientifically sound evaluation of agri-environment schemes. Since 2001, broader comparisons have been made, in a number of European countries, but the results again showed only small positive (if any) effects on what was the stated target of the environmental service rewards. 
Table 10. Sub-criteria (numbering continued from Table 9) and indicators for criterion III. 'Conditional: service and compensation are dynamically linked'; the large (bolded) asterix indicates the stage (within a row) where the criterion is most relevant

\begin{tabular}{|c|c|c|c|c|c|}
\hline Sub-criteria & Indicator & $\begin{array}{l}\text { Sco- } \\
\text { ping }\end{array}$ & $\begin{array}{l}\text { Nego- } \\
\text { tiating }\end{array}$ & $\begin{array}{l}\text { Imple- } \\
\text { menting }\end{array}$ & $\begin{array}{l}\text { Evalu- } \\
\text { ating }\end{array}$ \\
\hline \multirow{5}{*}{$\begin{array}{l}\text { 8. ES-reward agreements } \\
\text { strike a balance between } \\
\text { outcome-based rewards, } \\
\text { targets for agro-ecosysem } \\
\text { conditions, activity- } \\
\text { centered incentives, support } \\
\text { for community-scale } \\
\text { resource management and } \\
\text { establishment of } \text { trust }\end{array}$} & $\begin{array}{l}\text { Outcome-based quantification of } \\
\text { effects on welfare (livelihood } \\
\text { options) and identified } \\
\text { environmental services }\end{array}$ & * & * & * & $*$ \\
\hline & $\begin{array}{l}\text { II. Rewards linked to a pre- } \\
\text { defined condition of the agro- } \\
\text { ecosystem (e.g. maintenance of } \\
\text { forest cover, presence of } \\
\text { indicator organisms) }\end{array}$ & * & $*$ & & \\
\hline & $\begin{array}{l}\text { III. Activity-based rewards for } \\
\text { labour invested relative to wage } \\
\text { rates }\end{array}$ & & * & * & \\
\hline & $\begin{array}{l}\text { IV. Community management } \\
\text { plans and the sanctions to } \\
\text { implement them }\end{array}$ & & $*$ & $*$ & \\
\hline & $\begin{array}{l}\text { V. Trust and respect for } \\
\text { objectives of the rural } \\
\text { communities }\end{array}$ & & $*$ & * & \\
\hline \multirow{3}{*}{$\begin{array}{l}\text { 9. Sanctions exist to deal } \\
\text { with non-compliance by } \\
\text { contract partners, within } \\
\text { the human and legal rights } \\
\text { of both sides (linked to exit } \\
\text { strategy in 7) }\end{array}$} & $\begin{array}{l}\text { Options to reduce/withdraw the } \\
\text { rewards if ES provision is non- } \\
\text { existent }\end{array}$ & $*$ & $*$ & * & \\
\hline & $\begin{array}{l}\text { Ways to deal with free riders and } \\
\text { defectors within the community }\end{array}$ & $*$ & $*$ & * & \\
\hline & $\begin{array}{l}\text { Options to reduce/withdraw the } \\
\text { service when rewards are not } \\
\text { provided }\end{array}$ & $*$ & $*$ & * & \\
\hline \multirow{2}{*}{$\begin{array}{l}\text { 10. ES reward agreements } \\
\text { acknowledge the potential } \\
\text { of environmental variability } \\
\text { and change, 'third-party } \\
\text { roles' (incl. climate change) } \\
\text { to affect the ecosystem and } \\
\text { its ES provision }\end{array}$} & $\begin{array}{l}\text { The way environmental 'force } \\
\text { majeur' (including 'extreme } \\
\text { climatic events', invasive exotic } \\
\text { organisms) is accounted for in } \\
\text { risk sharing clauses }\end{array}$ & & $*$ & $*$ & \\
\hline & $\begin{array}{l}\text { The way the influence of other } \\
\text { actors is accounted for as 'force } \\
\text { majeur' }\end{array}$ & & * & $*$ & \\
\hline
\end{tabular}

\subsection{Pro-poor}

The Millennium Development Goals provide a number of different entry points for the publicly supported goals of poverty reduction, and many countries have since developed Poverty Reduction Strategies. The MDG focus on health and income have direct links to environmental quality, through the provision of clean water and sanitation, and rural livelihood strategies, respectively. The MDG focus on education may relate to CRES as it will facilitate communication and negotiation processes. These relationships to CRES may, however, remain rather indirect.

Ethical principles suggest that respect, tangible benefits to poor stakeholders engaged in the CRES processes, social justice, gender, welfare and intergenerational equity need to be considered in any rural development activity, including CRES, at least as a point for potential 
concern. As indicated in Figure 6 the space between the opportunity costs for buyers and sellers can be partitioned in multiple ways. 'Pro-poor' may be interpreted as indicating that an additional portion of the value would go to the seller where these are poor smallholders. Of course, this conflicts with the direct interests of buyers and intermediaries - unless the next steps in the chain have an explicit appreciation for such allocation and/or public sector regulators or civil society organizations working in the broad public interest are able to influence such pro-poor outcome. Since CES often are linked to land area, there is an obvious risk of enhancing disparities in local distribution of income even if all local people are relatively poor on a global scale. In this context, we distinguish 'weakly' and 'strongly' propoor mechanisms. By weakly pro-poor, we mean mechanisms that redistribute income from relatively well-off buyers to relatively poor sellers, but that don't actually improve the income distribution among those relatively poor sellers. The term 'strongly pro-poor' may be used for any mechanisms that actually improves equity locally (that have the greatest positive impact on the relatively poorest among suppliers). Employment opportunities for landless laborers at a wage rate above the current local one may be an example of 'pro-poor' mechanisms. Although there is substantial variation in the relative distribution of poverty and political power across the landscape, in substantial parts of the developing world, fertile alluvial plains that were formed by deposition of materials eroded from the mountains and uplands have been the basis of economic and political power since historical times, especially where the mouth of a navigable river allowed participation in the emerging global trade in forest and agricultural products. In much of Asia the 'upland people' have not been part of mainstream political processes and the remaining forests of the uplands have been associated with political dissidents and rebels. Quantitative analysis of patterns of rural income still tends to confirm substantive inequalities along an upland - lowland gradient - although there are important exceptions in situations where fertile upland plains with favourable climate have taken on the centre role and coastal zones of low accessibility the periphery role. Figure 13 indicates a number of stages in the (stereotypical) relationship between lowland centres of power and upland people (Van Noordwijk et al., 2005):

1. Unequal power relations are so clear and upland people so poorly organized that the conflicts are subdued

2.Upland groups are well organized and can exploit the geographic strengths of their position to balance the lack of numerical power in open conflicts

3.Recognition of the benefits of cooperation emerges when the biophysical basis of 'conflicts (e.g. the perception that all lowland problems with water flow are caused by deforestation of the uplands) is challenged and/or when the costs of continued conflict are seen to be excessive relative to the expected gains

4. With realization of the potential benefits of cooperation, the traditional mistrust and negative perceptions (where lowlanders look down upon upland people, as strange as this may sound) become replaced by emerging positive relations

5.The establishment of realistic, conditional and voluntary CRES becomes possible and provides positive feedback to the emerging trust.

Where 'lack of voice' is an important dimension of rural poverty, the emergence of CRES may require significant steps in reducing inequality in the negotiation stage - but can, if successful, become an important contributor to poverty alleviation. Positive effects of CRES on poverty reduction may thus derive from a number of different pathways. Eight have been recognized so far in the RUPES program (Table 11). They address different dimensions of (rural) poverty. 

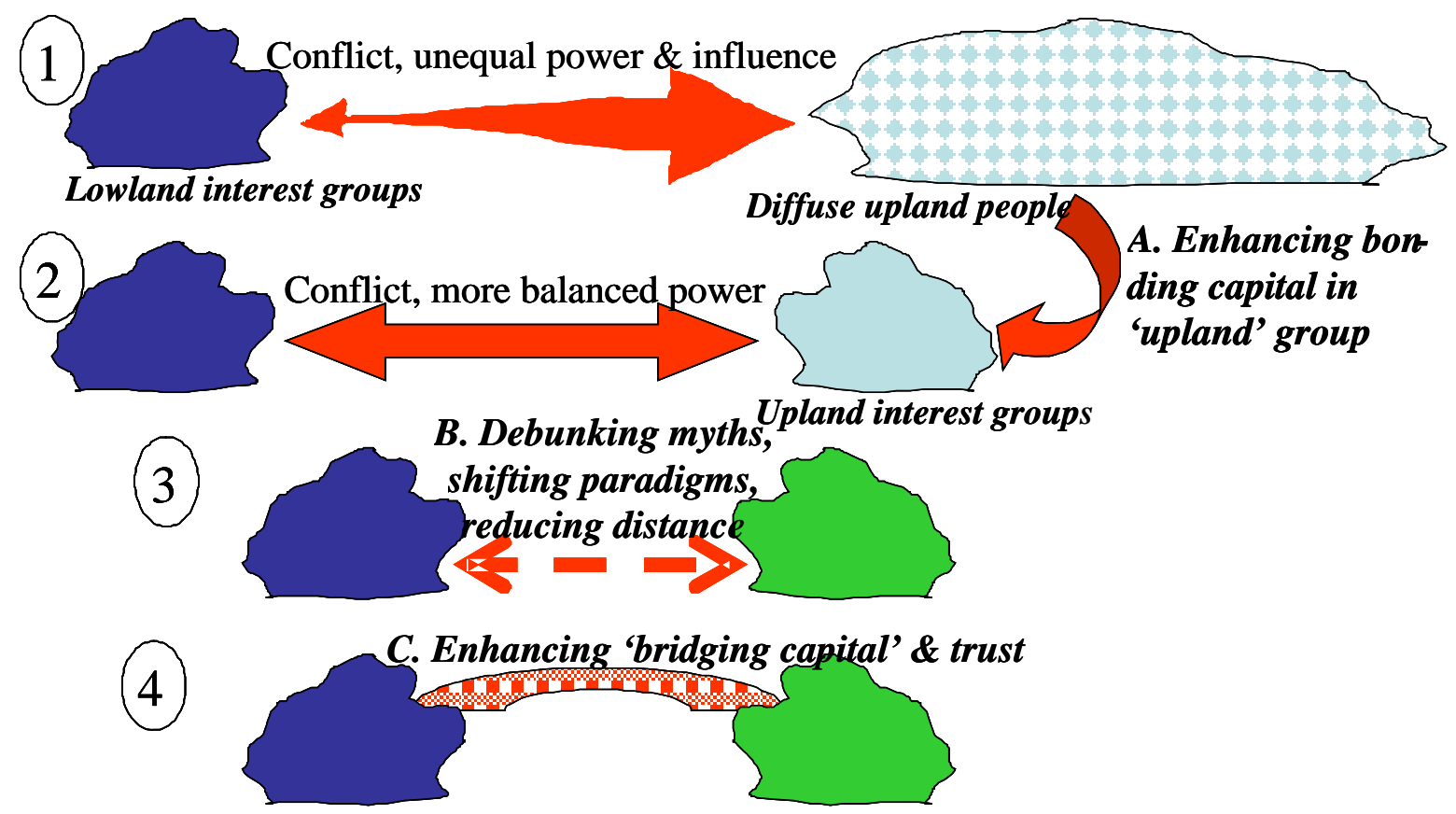

D. Strengthening the 'CRES bridge': clear Criteria \& Indicators monitoring...
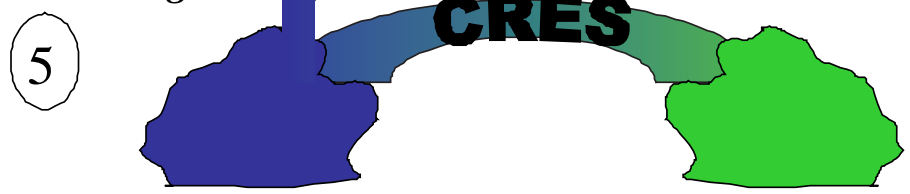

Figure 13. Stages (1...5) in the relationship between 'lowland' and 'upland' stakeholders and activities (A...D) that can contribute to more equitable and productive relations, balancing 'bonding' and 'bridging' forms of social capital (van Noordwijk et al. 2005)

Table 11. Pathways for ES Reward schemes to alleviate poverty as recognized in the RUPES program

\section{Pathway}

P1

P2

P3

P4

P5

P6

P7

P8
Stop negative 'drivers' that enhance poverty and degrade environmental services ('PUPES')

Enhance local environmental services and resources (e.g. regular supply of clean water, access to beneficial plant and animal resources)

Enhanced security of tenure, reduced fear of eviction or 'take-over' by outsiders, allowing investment in land resources; increased asset value

Enhanced trust with (local) government, increased 'say' in development decisions

Increased access to public services (health, education, accessibility, security)

Payment for labour invested at a rate at least equal to opportunity cost of labour

Increased access to investment funds (microcredit or otherwise) for potentially profitable activities

Entrepreneurism in selling 'commoditized' environmental services

\section{Poverty dimension addressed}

Assets, Risk, Health, Indirect income

Health, Assets

Assets, Risk, Indirect income

Empowerment, Reduced informal taxes (corruption) Health, Education, Indirect income

Direct income (labour based)

Indirect income

Direct income (land based) 
Gender-based differences in access to resources and participation in public decision making may be seen as an additional aspect of poverty. Although proper analysis of the gender dimension of CRES would require a separate chapter, a number of hypotheses can be formulated for the different stages of CRES negotiation:

1.In situations where the relationship between rural communities and representatives of government is characterized by latent or open conflict over access to land and other natural resources, there is limited scope for gender-related differences in perspective and action to be expressed.

2. Gender-related differences in perspective and preference need to be taken into account in the scoping and stakeholder identification stage by 'honest brokers' to support the emergence of efficient and sustainable mechanisms, as gender-specific perspectives will otherwise affect the implementation of agreements.

3. Gender-based differences in appreciation for local environmental services can either strengthen or weaken the negotiation position of a local community, depending on the externally perceived level of overall threat to the environmental service at stake and the 'optimum threat' level, as a high local appreciation of environmental services undermines the additionality argument of providing services for outside beneficiaries, but strengthens the trust in implementability.

4. Specific enhancement of the role of women in the negotiations over natural resource management with government and other external actors is possible and can meet externally set criteria and indicators of 'representativeness', but adds to the transaction costs.

5. Gender specific perspectives on the form of conditionality and the approach to monitoring compliance (at plan, activity, agroecosystem and/or environmental service level) can reduce the implementation costs and enhance sustainability and effectiveness, justifying the initial increase in transaction costs.

Table 12. Sub-criteria (numbering continued from Table 8) and indicators for criterion IV. 'Pro-poor: equity effects are taken into account and mechanisms selected are positively biased towards poor stakeholders'; the large (bolded) asterix indicates the stage (within a row) where the criterion is most relevant

\begin{tabular}{|c|c|c|c|c|c|}
\hline Sub-criteria & Indicators & $\begin{array}{l}\text { Sco- } \\
\text { ping }\end{array}$ & $\begin{array}{l}\text { Nego- } \\
\text { tiating \& } \\
\text { stake- } \\
\text { holder } \\
\text { analysis }\end{array}$ & $\begin{array}{l}\text { Imple- } \\
\text { men- } \\
\text { ting }\end{array}$ & $\begin{array}{l}\text { Eva- } \\
\text { lua- } \\
\text { ting }\end{array}$ \\
\hline \multirow{4}{*}{$\begin{array}{l}\text { 11.ES reward mechanisms } \\
\text { support 'sustainable } \\
\text { development' pathways out of } \\
\text { poverty for achieving } \\
\text { Millennium Development } \\
\text { Goals, by addressing the } \\
\text { priorities (and criteria...) of } \\
\text { 'poor' stakeholders }\end{array}$} & $\begin{array}{l}\text { Role of control over land, rather } \\
\text { than labour, as basis for ES } \\
\text { rewards }\end{array}$ & $*$ & $*$ & & \\
\hline & $\begin{array}{l}\text { Comparative advantage of poor } \\
\text { ES providers }\end{array}$ & $*$ & $*$ & & \\
\hline & $\begin{array}{l}\text { Equity impact of exclusion and } \\
\text { inclusion }\end{array}$ & $*$ & $*$ & & * \\
\hline & $\begin{array}{l}\text { Gender impact of the ES-enhan- } \\
\text { cing activities, the rewards and its } \\
\text { effects on local ES }\end{array}$ & $*$ & $*$ & & * \\
\hline
\end{tabular}




\begin{tabular}{|c|c|c|c|c|c|}
\hline & $\begin{array}{l}\text { Inter-generational equity survival } \\
\text { issue rather than optimization; } \\
\text { negative 'discount rate' on } \\
\text { environmental qualities to reflect } \\
\text { future scarcity }\end{array}$ & & $*$ & & * \\
\hline & $\begin{array}{l}\text { Remove unnecessary trans-action } \\
\text { costs and investments, and who } \\
\text { bears the burden }\end{array}$ & $*$ & $*$ & & \\
\hline & $\begin{array}{l}\text { Proportion of total payment to } \\
\text { stakeholders below local poverty } \\
\text { line }\end{array}$ & & $*$ & * & * \\
\hline & $\begin{array}{l}\text { Institutions and intermediaries } \\
\text { exist that effectively engage the } \\
\text { disadvantaged stakeholders }\end{array}$ & $*$ & $*$ & & * \\
\hline & $\begin{array}{l}\text { Successful capacity building } \\
\text { efforts exist aimed at full } \\
\text { participation }\end{array}$ & $*$ & $*$ & & * \\
\hline & $\begin{array}{l}\text { Interventions contribute to local } \\
\text { livelihoods (employment effects) }\end{array}$ & & $*$ & $*$ & * \\
\hline & $\begin{array}{l}\text { Transparency in local } \\
\text { management of funds }\end{array}$ & & & $*$ & * \\
\hline \multirow[t]{3}{*}{$\begin{array}{l}\text { 12. ES reward mechanisms } \\
\text { reduce asset insecurity } \\
\text { (including access to land) }\end{array}$} & $\begin{array}{l}\text { Reform of regulations aimed at } \\
\text { protecting ecosystems and their } \\
\text { ES (but unduly enhancing } \\
\text { poverty) }\end{array}$ & $*$ & $*$ & & \\
\hline & $\begin{array}{l}\text { Where poor groups benefit from } \\
\text { ES provided, tied to basic needs }\end{array}$ & $*$ & & $*$ & \\
\hline & $\begin{array}{l}\text { Risk management linked to } \\
\text { potential loss of land }\end{array}$ & & & & \\
\hline
\end{tabular}

\section{Discussion}

\subsection{Relations between the 4 classes of criteria}

After identifying sub-criteria and possible indicators for each of the 4 criteria, we can now reflect on the relations between them, across the 4 stages identified Table 13). Although we have so far presented the 4 criteria as representing independent axes, there are interactions. One can argue that either of the three 'effectiveness' criteria can partially substitute for the others:

- if the mechanism and reward levels are truly realistic, they don't need to be voluntary (and may be imposed on all citizens by a fair and benevolent society) and the need for constant learning through conditionality is not so obvious (unless overall conditions are changing and science is advancing);

- if the mechanism and reward levels are truly voluntary, they will reflect what parties think is realistic and are willing to pay and willing to accept;

- if the mechanisms and reward levels are truly conditional and part of an active learning cycle, it is less important that they have the details right on being realistic, as gradual adjustments are built in.

In reality, none of the three criteria can be met to the full extent, however, so none of them is redundant - but as a whole the set of criteria is probably 'over-specified': a partial match with each of the targets may suffice to reach the goals of effectiveness, efficiency and sustainability. However, the degree to which partial matches are sufficient is a matter for further empirical 
research, once the various yardsticks for measuring the indicators are agreed on. This conclusion is in line with the tentative conclusion of Wunder (2005) that a strict definition of Payments for Environmental Services leads to the inevitable conclusion that no current examples match the target, while there appears to be examples of at least partial success by mechanisms that don't meet all the criteria.

The role of pro-poor (and pro-gender-balance) mechanisms is still controversial. On one hand essential pre-conditions for entering into contracts on conditional delivery of environmental services are not met for many of the rural poor without secure land tenure, without trust in relations with outside agents, without ability to litigate if the other side does not meet contractual obligations, and without collateral to obtain financial capital at reasonable cost. Environmental service 'rewards' that make progress in these pre-conditions (compare table 8) may be more relevant than financial payments of low amounts per capita.

Yet, without a 'pro-poor' or 'pro-gender-balance' approach, it is likely that the resulting mechanisms will increase inequity and continue to impose costs on the poor while providing benefits for the better-off. All mechanisms that take control over land as their basis are likely to fall into this category. But seemingly 'neutral' mechanisms proposed by conservation agencies, may well lead to a situation where the rural poor have to pay for the conservation priorities set by those who are better off (see Box 7).

In further reflection on the 4 levels of conditionality introduced in Figure 10, we may recognize four contrasting 'paradigms' in the current debate (Table 14):

A. Advocates of strict conditionality at outcome level, with financial payments as the least patronizing and most flexible instrument (Wunder 2005, 2006),

B. Benefits (rewards or payments) for land users who voluntarily accept restrictions on their land use, with conditionality at the level of the land cover (observable), assuming that this leads to the environmental services of interest,

C. Co-management of the landscape with shared responsibility, conditional tenure and direct rewards for labour invested,

D. Delegating authority and responsibility to local stakeholders.

Intermediate positions and hybrids are possible. 
Table 13. Summary of criteria for reward mechanisms for environmental services

\begin{tabular}{|c|c|c|c|}
\hline \multicolumn{4}{|c|}{ Stage } \\
\hline \multicolumn{4}{|c|}{ A. Effectiveness, Efficiency and Sustainability } \\
\hline \multirow[t]{4}{*}{ I. Realistic } & \multirow[t]{4}{*}{ Scoping } & \multirow{4}{*}{$\begin{array}{l}\text { Effectively mi- } \\
\text { tigates, reduces } \\
\text { or avoids } \\
\text { threats to ES } \\
\text { for all parties } \\
\text { involved }\end{array}$} & $\begin{array}{l}\text { 1. A broadly shared perception of cause-effect } \\
\text { relations links threats to ES or to the ecosystem } \\
\text { that provides ES, to potential activities to } \\
\text { reduce or avoid these threats by identifiable } \\
\text { actors at a relevant temporal and spatial scale }\end{array}$ \\
\hline & & & $\begin{array}{l}\text { 2. The value to ES-beneficiaries of reduction or } \\
\text { avoidance of the threats, relative to alternative } \\
\text { ways to meet their needs, is substantive (within } \\
\text { the context of the key actors) }\end{array}$ \\
\hline & & & $\begin{array}{l}\text { 3. There are opportunity costs and/or resource } \\
\text { access constraints for the potential 'ES } \\
\text { providers' that can be off-set or overcome } \\
\text { without major negative 'external effects' (leakage) }\end{array}$ \\
\hline & & & $\begin{array}{l}\text { 4. The threat to the ES and its reduction (or } \\
\text { avoidance) by ES providers can be assessed and } \\
\text { monitored in a transparent way, as a basis for } \\
\text { conditional incentives }\end{array}$ \\
\hline \multirow[t]{3}{*}{$\begin{array}{l}\text { II. } \\
\text { Voluntary }\end{array}$} & \multirow{3}{*}{$\begin{array}{l}\text { Stake- } \\
\text { holder } \\
\text { analysis }\end{array}$} & \multirow{3}{*}{$\begin{array}{l}\text { Engagement in- } \\
\text { volves choice } \\
\text { rather than } \\
\text { being the object } \\
\text { of regulation }\end{array}$} & $\begin{array}{l}\text { 5. Legitimacy at individual level: representation is } \\
\text { subject to checks and balances }\end{array}$ \\
\hline & & & $\begin{array}{l}\text { 6. Effective voice of all stakeholders is heard; free } \\
\text { and prior informed consent principles apply }\end{array}$ \\
\hline & & & $\begin{array}{l}\text { 7. Adaptiveness of the mechanism includes a } \\
\text { time frame for review and exit strategy }\end{array}$ \\
\hline \multirow{4}{*}{$\begin{array}{l}\text { III. } \\
\text { Conditional }\end{array}$} & \multirow{4}{*}{$\begin{array}{l}\text { Negotia } \\
\text {-tion \& } \\
\text { imple- } \\
\text { menta- } \\
\text { tion }\end{array}$} & \multirow{4}{*}{$\begin{array}{l}\text { Service and re- } \\
\text { wards or com- } \\
\text { pensation are } \\
\text { dynamically } \\
\text { linked }\end{array}$} & 8. ES-reward agreements strike a balance between \\
\hline & & & $\begin{array}{l}\text { outcome-based rewards, targets for agro- } \\
\text { ecosystem conditions, activity-centered } \\
\text { incentives, support for community-scale resource } \\
\text { management and establishment of trust }\end{array}$ \\
\hline & & & $\begin{array}{l}\text { 9. Sanctions exist to deal with non-compliance } \\
\text { by contract partners, within the human and legal } \\
\text { rights of both sides (linked to exit strategy in } 7 \text { ) }\end{array}$ \\
\hline & & & $\begin{array}{l}\text { 10. ES reward agreements acknowledge the } \\
\text { potential of environmental variability and } \\
\text { change, 'third-party roles' (incl. climate change) to } \\
\text { affect the ecosystem and its ES provision }\end{array}$ \\
\hline \multicolumn{4}{|l|}{ B. Equity } \\
\hline \multirow[t]{2}{*}{ IV. Pro-poor } & \multirow[t]{2}{*}{$\begin{array}{l}\text { Al1 } \\
\text { stages }\end{array}$} & \multirow{2}{*}{$\begin{array}{l}\text { Mechanisms se- } \\
\text { lected are } \\
\text { positively biased } \\
\text { towards dis- } \\
\text { advantaged } \\
\text { stakeholders }\end{array}$} & $\begin{array}{l}\text { 11.ES reward mechanisms support 'sustainable } \\
\text { development' pathways out of poverty for } \\
\text { achieving Millennium Development Goals, by } \\
\text { addressing the priorities (and criteria...) of 'poor' } \\
\text { stakeholders }\end{array}$ \\
\hline & & & $\begin{array}{l}\text { 12. ES reward mechanisms reduce asset insecurity } \\
\text { (including access to land) }\end{array}$ \\
\hline
\end{tabular}




\section{Box 7. Stopping encroachment into a national park by reducing profitability of uncertified coffee production...}

The Bukit Barisan Selatan national park in Sumatra is recognized by the UNESCO as a World Heritage Site, but declaration of the park has not been effective in reducing the rate of forest conversion (Gaveau et al., 2007), with encroachment for coffee production next to illegal logging as primary concern for conservation agencies. As direct 'law enforcement' approaches have failed to be effective for a variety of reasons, a major international conservation NGO recently started a campaign to put pressure on all coffee importers from Lampung to ensure that they don't buy coffee 'tainted' with illegal coffee. Although only $5 \%$ of the coffee from Lampung is produced in the park, it may be mixed with up to $45 \%$ of all coffee exported. To make illegal coffee less profitable, and in the hope that the farmers/ squatters will give up, the NGO suggests that a 'certification of origin' scheme will be required by all coffee importers who want to avoid getting a bad name. That such a certification scheme will have costs for the $95 \%$ of coffee producers outside of the park has not been part of the considerations and so far no solution has been suggested for this aspect. Most of Lampung coffee is produced by smallholders who operate above the poverty line when prices are good, but fall back below if the prices crash. The discussion continues at the time of writing. 
Table 14. Four paradigms related to the different levels of conditionality (compare Figure 10)

\begin{tabular}{|c|c|c|c|}
\hline Paradigm A & Paradigm B & Paradigm C & Paradigm D \\
\hline $\begin{array}{l}\text { Markets Regulating Payments for actual } \\
\text { Environmental Services provided } \\
\text { (PES) - level } 1\end{array}$ & $\begin{array}{l}\text { Rewarding/Paying Land Users for Accepting } \\
\text { Restrictions on their Land Use - level } 2\end{array}$ & $\begin{array}{l}\text { Co-Managing Landscapes for } \\
\text { Reducing Poverty and Enhancing ES - } \\
\text { level } 3\end{array}$ & $\begin{array}{l}\text { Integrated Conservation and } \\
\text { Development Projects (ICDP's) - } \\
\text { interactions at level } 4\end{array}$ \\
\hline \multicolumn{4}{|l|}{ Type and Level of Rewards/Payments } \\
\hline - Recurrent monetary payments & - Recurrent monetary payments & $\begin{array}{l}\text { - Negotiated, conditional tenure } \\
\text { security } \\
\text { - Reduction of current land use } \\
\text { conflicts }\end{array}$ & $\begin{array}{l}\text { - Investment in ecofriendly } \\
\text { enterprises will lead to long-term } \\
\text { payoffs for both rural welfare and } \\
\text { conservation }\end{array}$ \\
\hline - New flows of income & $\begin{array}{l}\text { - Substantial new funding } \& \text { investment } \\
\text { resources for poverty reduction }\end{array}$ & $\begin{array}{l}\text { - Reduction of conflicts and collateral } \\
\text { damage to both environment and } \\
\text { rural welfare } \\
\text { - Modest new financial transfers }\end{array}$ & $\begin{array}{l}\text { Trust between conservation } \\
\text { agencies and rural communities } \\
\text { will allow for mutual benefit }\end{array}$ \\
\hline $\begin{array}{l}\text { - Price level is fully negotiable, the } \\
\text { market price is the right one (by } \\
\text { definition) }\end{array}$ & $\begin{array}{l}\text { - Fair price for sellers depends on knowledge } \\
\text { of opportunity costs for the land user } \\
\text { - Buyers 'efficiency' is protected by requiring } \\
\text { 'additionality above baselines' }\end{array}$ & $\begin{array}{l}\text { - Improved public services (above } \\
\text { baseline) can be a suitable form of } \\
\text { rewards }\end{array}$ & $\begin{array}{l}\text { - Essentially public investment to } \\
\text { enhance welfare at the level of } \\
\text { society }\end{array}$ \\
\hline \multicolumn{4}{|l|}{ Target Population; Poverty Effects } \\
\hline $\begin{array}{l}\text { - Land owners or at least } \\
\text { persons/agencies with secure de facto } \\
\text { control }\end{array}$ & $\begin{array}{l}\text { - Land owners or at least persons/agencies } \\
\text { with secure de facto control }\end{array}$ & - Any marginalized communities, incl. & $\begin{array}{l}\text { - Uplands and 'indigenous' people in } \\
\text { and surrounding areas of high } \\
\text { conservation value }\end{array}$ \\
\hline $\begin{array}{l}\text { No explicit poverty target, but } \\
\text { trickle down economic benefits are } \\
\text { expected } \\
\text { - Money is the most universal form of } \\
\text { payment, anything else is } \\
\text { patronizing }\end{array}$ & $\begin{array}{l}\text { - Pro-poor mechanisms can be constructed } \\
\text { through targeted financial transfers }\end{array}$ & $\begin{array}{l}\text { - Monetary flows can be captured by } \\
\text { local elites and diverted } \\
\text { - Disadvantaged groups prefer 'public } \\
\text { - Rervices' } \\
\text { - Rewards based on health, education, } \\
\text { roads, access may be effective and } \\
\text { 'pro poor' }\end{array}$ & $\begin{array}{l}\text { - Poverty targets are embedded in } \\
\text { the choice for the site }\end{array}$ \\
\hline
\end{tabular}




\begin{tabular}{|c|c|c|c|}
\hline \multicolumn{4}{|c|}{ Assumed characteristics of the environmental service } \\
\hline $\begin{array}{l}\text { - The ES is 'divisible' and at least } \\
\text { proportional to the activity of } \\
\text { providers } \\
\text { - Exclusion from the service is possible } \\
\text { - 'Optimum levels of threat' are the main } \\
\text { selling point for providers }\end{array}$ & $\begin{array}{l}\text { Land use prescriptions are } \\
\text { the most effective way of } \\
\text { guaranteeing persistence of } \\
\text { the service, as they can be } \\
\text { easily monitored and } \\
\text { understood }\end{array}$ & $\begin{array}{l}\text { - Environmental services are 'emergent } \\
\text { properties' and only exist if all land users are } \\
\text { involved } \\
\text { - ES thus require land use planning \& } \\
\text { management } \\
\text { - Need trust, shared responsibility for effective co- } \\
\text { management of landscapes }\end{array}$ & $\begin{array}{l}\text { - Integrity of the core protected } \\
\text { area implies continuity of the } \\
\text { environmental services } \\
\text { - The main function of the 'buffer } \\
\text { zone' is to provide local income } \\
\text { while protecting integrity of the } \\
\text { core area }\end{array}$ \\
\hline \multicolumn{4}{|c|}{ Attribution of ES; Conditionality of 'Rewards' } \\
\hline $\begin{array}{l}\text { No LU prescriptions / micro- } \\
\text { management as long as the service is } \\
\text { there payments will continue; } \\
\text { stimulates local inventiveness and } \\
\text { increase in efficiency of 'producing' the } \\
\text { service desired }\end{array}$ & $\begin{array}{l}\text { - Clear, identifiable ES can be } \\
\text { attributed to providers \& } \\
\text { activities }\end{array}$ & $\begin{array}{l}\text { - Complex causality, no simple attribution possible } \\
\text { in many cases } \\
\text { - Public funding justified when ES provision } \\
\text { (result) depends on level of participation } \\
\text { - (Broader 'emergent properties' of ES provision) }\end{array}$ & $\begin{array}{l}\text { - Integrity of the core area is the } \\
\text { target }\end{array}$ \\
\hline $\begin{array}{l}\text { - Potentially any positive externality } \\
\text { (lateral benefit flow) or desirable } \\
\text { condition can be rewarded } \\
\text { - Payments are conditional to 'service } \\
\text { indicators' }\end{array}$ & $\begin{array}{l}\text { - Only those land use } \\
\text { prescriptions that generate } \\
\text { lateral benefit flows that } \\
\text { exceed a baseline of } \\
\text { 'business as usual' can be } \\
\text { rewarded }\end{array}$ & $\begin{array}{l}\text { - Must have (enforce) baseline of 'good' behaviour } \\
\text { - Expected/normative quality standard is non- } \\
\text { trivial } \\
\text { - Rewards must build on standard of improved } \\
\text { care }\end{array}$ & $\begin{array}{l}\text { The investment cannot be } \\
\text { withdrawn, conditionality is } \\
\text { replaced by 'trust' and self- } \\
\text { interest in mutual goals }\end{array}$ \\
\hline \multicolumn{4}{|l|}{ Local Institutions } \\
\hline $\begin{array}{l}\text { Local institutions can help reduce } \\
\text { transaction costs and provide } \\
\text { economies of scale }\end{array}$ & $\begin{array}{l}\text { - Strong local organizations } \\
\text { needed } \\
\text { - Ready for project cycle } \\
\text { transactions and } \\
\text { negotiations }\end{array}$ & $\begin{array}{l}\text { - Local conflict resolution needed } \\
\text { - Access to info about landscape level ES is } \\
\text { priority } \\
\text { - Environmental education needed: formal \& } \\
\text { informal channels }\end{array}$ & $\begin{array}{l}\text { - Environmental education needed: } \\
\text { formal \& informal channels }\end{array}$ \\
\hline \multicolumn{4}{|l|}{ Priority Actions } \\
\hline $\begin{array}{l}\text { - Create replicable, payment models } \\
\text { - Reduce transaction costs \& provide } \\
\text { economies of scale }\end{array}$ & $\begin{array}{l}\text { - Establish clear guidelines of } \\
\text { land use practices to be } \\
\text { avoided/ promoted } \\
\text { - Measure opportunity costs }\end{array}$ & $\begin{array}{l}\text { Stop lose-lose scenarios for poverty \& } \\
\text { environment (Prevent/reduce 'PUPES') }\end{array}$ & $\begin{array}{l}\text { Establish trust in clearly } \\
\text { prioritized areas of high } \\
\text { conservation value }\end{array}$ \\
\hline
\end{tabular}


Table 15. Tentative ranking $(1=$ weak, $2=$ medium, $3=$ strong $)$ of the land use dependence, relative CRES potential and pro-poor options of different types of environmental services

\section{Environmental service function}

Protecting the integrity of conservation areas by preventing loss of habitat and threats at population level in the areas directly around core protection areas

Providing habitat for a sub-set of the original fauna and flora inside agriculturally used landscapes

Maintaining connectivity between protected areas via corridors

Creating opportunities for local-level 'restoration', in landscapes where connectivity is still maintained

Various forms of ex situ conservation

Protecting natural forest area, peat soils and other carbon storage areas

Protecting above- and/or belowground carbon stocks in areas used for (agro)forestry and/or agriculture

\begin{tabular}{|c|c|}
\hline $\begin{array}{l}\text { LU } \\
\text { depen- } \\
\text { dence }\end{array}$ & $\begin{array}{l}\text { CRES } \\
\text { potential }\end{array}$ \\
\hline
\end{tabular}

Restoration, increase in tree cover (in a 'sustainable harvest' regime the time-averaged $\mathrm{C}$ stock of a land use system does not depend on the growth rate, but on maximum stock at time of harvest)

Accumulating wood and other products derived from recent plant production in, for example, the form of houses, furniture, paper, organic waste dumps

Regulation of pests and diseases

Detoxification of air, water, food

Spiritual, religious and aesthetic values

Opportunity for active recreation (ecotourism)

Ecological knowledge

Allowing extraction of potentially renewable resources

Non-renewable resource mining

Nutrient and water supply for agricultural crops, fodder and trees

Biotic relationships: pollination, pests, diseases and their control

Water transmission (total water yield per unit rainfall)

Buffering (above average river discharge per unit above average rainfall)

Gradual release of stored water supporting dry-season flows

Maintaining water quality (relative to that of rainfall)

Stability of slopes, absence of landslides

Tolerable intensities of net soil loss from slopes by erosion

Microclimate effects on air humidity and temperature

A simple way of stating what it takes to get effective ES reward mechanisms going is to get the science right ('realistic'), the institutions right ('conditional, pro-poor') and the right-left politics right ('voluntary'). We hope that the further articulation of these 
criteria as formulated here can be further tested in its applicability by analysis of existing cases, and in helping many new examples emerge.

\subsection{Hypotheses}

Table 16. Hypotheses for further research on CRES mechanisms

\begin{tabular}{|c|c|c|}
\hline & Hypotheses & Comments \\
\hline 1 & $\begin{array}{l}\text { A partial mimicking of the realistic, conditional and vo- } \\
\text { luntary characteristics of a 'market' is sufficient to achieve } \\
\text { effectiveness, efficiency, sustainability and equity for ES } \\
\text { reward mechanisms }\end{array}$ & $\begin{array}{l}\text { Most mechanisms known to date } \\
\text { share 'negotiation' elements with a } \\
\text { 'market', but also imply 'shared } \\
\text { responsibility' }\end{array}$ \\
\hline 2 & $\begin{array}{l}\text { Indicators for the monitoring stage of voluntary, conditional } \\
\text { reward mechanisms need, for the sake of sustainability of the } \\
\text { mechanism and decreased transaction costs, themselves to be } \\
\text { the outcome of a negotiation process and need to address } \\
\text { 'compliance' issues at input (activity) level to secure the } \\
\text { sellers interests and the effects on the actual ES involved to } \\
\text { satisfy the buyers }\end{array}$ & $\begin{array}{l}\text { Many existing mechanisms for } \\
\text { 'watershed functions' seem to fall } \\
\text { short on being 'realistic' and lack } \\
\text { transparent criteria for monitoring } \\
\text { and evaluation. Most criteria we } \\
\text { know of relate to 'compliance' of } \\
\text { activities rather than effects on the } \\
\text { ES involved }\end{array}$ \\
\hline 3 & $\begin{array}{l}\text { Monitoring and reward conditionality based on ES outcome } \\
\text { is desirable from an adaptive management perspective, but } \\
\text { applicability is constrained by a) costs of monitoring, b) } \\
\text { difficulty in attribution of changes across actors because of } \\
\text { exogenous environmental variability, c) limited ability by } \\
\text { (poor) stakeholders to absorb risks and d) formalizing } \\
\text { punishment of the poor runs against social norms and ethics }\end{array}$ & $\begin{array}{l}\text { Adaptive management theory } \\
\text { suggests the importance of short } \\
\text { feedback and learning loops, but } \\
\text { most ES rewards apply to situations } \\
\text { with complex causality. } \\
\text { Development of a long-term 'trust' } \\
\text { relationship is an essential part of } \\
\text { mechanisms known to date }\end{array}$ \\
\hline 4 & $\begin{array}{l}\text { Uniqueness and requirement for site-specificity of each } \\
\text { negotiation can be achieved at manageable transaction costs } \\
\text { if better cross-site learning and a semi-structured approach } \\
\text { become available, as there indicators for scoping and } \\
\text { negotiating stage can be shared more widely than those for } \\
\text { the implementation and monitoring stage (compare } \\
\text { hypothesis 2) }\end{array}$ & $\begin{array}{l}\text { Designs for 'rapid hydrological } \\
\text { appraisal' and 'rapid agrobiodi- } \\
\text { versity appraisal', both in the } \\
\text { context of rewards for ES are aimed } \\
\text { at providing cost-effective support } \\
\text { to site-specific negotiations; their } \\
\text { applicability remains to be tested. }\end{array}$ \\
\hline 5 & $\begin{array}{l}\text { Indicators needed to establish causality and realistic rewards } \\
\text { in the scoping and negotiation stage typically will not be } \\
\text { appropriate and cost-effective for assessing conditionality } \\
\text { and impact }\end{array}$ & $\begin{array}{l}\text { The requirements for data differ } \\
\text { between the stages, focussing on } \\
\text { causality (process) early on and } \\
\text { spatial variability (pattern) at } \\
\text { compliance stage }\end{array}$ \\
\hline 6 & $\begin{array}{l}\text { More effort and higher quality of preparatory work by } \\
\text { intermediaries in the scoping and negotiation stage will be } \\
\text { essential for achieving sustainable, pro-poor outcomes, } \\
\text { because of the impediments to imposing conditionality and } \\
\text { outcome-based indicators }\end{array}$ & $\begin{array}{l}\text { Linked to hypotheses } 3 \text {. As there is } \\
\text { limited scope for mid-way } \\
\text { corrections, it is important to get } \\
\text { started on the right track, esp. } \\
\text { where actors are poor }\end{array}$ \\
\hline 7 & $\begin{array}{l}\text { In situations where the relationship between rural } \\
\text { communities and representatives of government is } \\
\text { characterized by latent or open conflict over access to land } \\
\text { and other natural resources, there is limited scope for local } \\
\text { differences in wealth and gender-related differences in } \\
\text { perspective and action to be expressed }\end{array}$ & $\begin{array}{l}\text { Under external conflict, an internal } \\
\text { 'closing of the ranks' tends to } \\
\text { prevail. External attention for } \\
\text { internal distinctions is perceived as } \\
\text { divisive. }\end{array}$ \\
\hline 8 & $\begin{array}{l}\text { Gender and wealth related differences in perspective and } \\
\text { preference need to be taken into account in the scoping and } \\
\text { stakeholder identification stage by 'honest brokers' to }\end{array}$ & $\begin{array}{l}\text { Although it may require some } \\
\text { diplomacy (compare hypothesis 7), } \\
\text { reliance on self-proclaimed }\end{array}$ \\
\hline
\end{tabular}




\begin{tabular}{|l|l|l|}
\hline & $\begin{array}{l}\text { support the emergence of efficient and sustainable } \\
\text { mechanisms, as gender and wealth specific perspectives will } \\
\text { otherwise affect the implementation of agreements }\end{array}$ & $\begin{array}{l}\text { 'representatives' is not sufficient, } \\
\text { and explicit attention to local } \\
\text { differences in roles, perceptions and } \\
\text { preferences is appropriate }\end{array}$ \\
\hline 9 & $\begin{array}{l}\text { Gender and wealth based differences in appreciation for local } \\
\text { environmental services can either strengthen or weaken the } \\
\text { negotiation position of a local community, depending on the } \\
\text { externally perceived level of overall threat to the environ- } \\
\text { mental service at stake and the 'optimum threat' level, as a } \\
\text { high local appreciation of environmental services undermines } \\
\text { the additionality argument of providing services for outside } \\
\text { beneficiaries, but strengthens the trust in implementability }\end{array}$ & $\begin{array}{l}\text { The wing the with qualitative evidence so } \\
\text { far, but lacks quantification }\end{array}$ \\
\hline 10 & $\begin{array}{l}\text { Specific enhancement of the role of (poor) women in the } \\
\text { negotiations over natural resource management with } \\
\text { government and other external actors is possible and can } \\
\text { meet externally set criteria and indicators of } \\
\text { 'representativeness', but adds to the 'transaction costs' of the } \\
\text { mechanism. }\end{array}$ & $\begin{array}{l}\text { The effects on transaction costs are } \\
\text { not quantified yet }\end{array}$ \\
\hline 11 & $\begin{array}{l}\text { Gender and wealth specific perspectives on the form of } \\
\text { conditionality and the approach to monitoring compliance } \\
\text { (at plan, activity, agroecosystem and/or environmental } \\
\text { service level) can reduce the implementation costs and } \\
\text { enhance sustainability and effectiveness, justifying the initial } \\
\text { increase in transaction costs }\end{array}$ & $\begin{array}{l}\text { Quantification is needed to make a } \\
\text { 'business case' rather than } \\
\text { normative preference for 'pro-poor' } \\
\text { CRES }\end{array}$ \\
\hline 12 & $\begin{array}{l}\text { Underwriting scoping and negotiation stages to ensure } \\
\text { sustainable pro-poor RES mechanisms can compete with } \\
\text { other development investment in achieving poverty } \\
\text { reduction }\end{array}$ & $\begin{array}{l}\text { Hypothesis remains to be tested at } \\
\text { relevant 'sustainability' scale, but } \\
\text { some positive, effective examples } \\
\text { exist (e.g. Sumber Jaya) }\end{array}$ \\
\hline
\end{tabular}




\subsection{Conclusions and recommendations to IDRC}

\begin{tabular}{|c|c|c|}
\hline & Issue & Action suggested \\
\hline 1 & $\begin{array}{l}\text { In countries with a history of strong regula- } \\
\text { tion of resource access, reform of land use } \\
\text { regulation aligned with development of RES } \\
\text { mechanisms is essential to balance rights, } \\
\text { resources and responsibilities and reduce the } \\
\text { poverty of excluded groups }\end{array}$ & $\begin{array}{l}\text { IDRC might consider linking follow-up } \\
\text { engagement on CRES to the Rights \& } \\
\text { Resources initiative }\end{array}$ \\
\hline 2 & $\begin{array}{l}\text { The more indicators for monitoring are } \\
\text { activity- rather than outcome-based, the } \\
\text { more urgent it is for the sustainability of the } \\
\text { mechanism to build in periodic evaluation } \\
\text { and reassessment into the agreements }\end{array}$ & $\begin{array}{l}\text { In all efforts to assist the design of ES } \\
\text { reward mechanisms, financial allowance } \\
\text { should be built-in to periodically assess } \\
\text { impacts and re-evaluate the mechanism }\end{array}$ \\
\hline 3 & $\begin{array}{l}\text { The current set of } 12 \text { (sub)criteria is proba- } \\
\text { bly over-determined but the necessary } \\
\text { minimum set appears to depend on local } \\
\text { context }\end{array}$ & \multirow{3}{*}{$\begin{array}{l}\text { Support the use of the typologies and cri- } \\
\text { teria as a framework for synthesis of } \\
\text { ongoing experience and the actual suc- } \\
\text { cess rate achieved, as well as for a prio- } \\
\text { ritization of future action research aimed } \\
\text { at increasing diversity of learning sites }\end{array}$} \\
\hline 4 & $\begin{array}{l}\text { The current set of } 12 \text { (sub)criteria probably } \\
\text { needs rephrasing (and/or reframing) to adapt } \\
\text { to the existing variation in culture, socio- } \\
\text { economic conditions and system of gover- } \\
\text { nance }\end{array}$ & \\
\hline 5 & $\begin{array}{l}\text { Specific attention for pro-poor and pro-gen- } \\
\text { der balance is so far based on normative } \\
\text { grounds rather than on the basis of } \\
\text { effectiveness and efficiency; testing the } \\
\text { 'business case' for pro-poor mechanisms } \\
\text { may well be the biggest challenge }\end{array}$ & \\
\hline
\end{tabular}




\section{References}

Axelrod, R. 1997. The Complexity of Cooperation: Agent-Based Models of Competition and Collaboration. Princeton University Press,

Aylward, B. and Echeverria, J. 2001. 'Synergies between Livestock Production and Hydrological Function in Arenal, Costa Rica'. Environment and Development Economics 6(3): 39-382

Berger, G., Kaechele, H. and Pfeffer, H. 2006. The greening of the European common agricultural policy by linking the European-wide obligation of set-aside with voluntary agri-environmental measures on a regional scale. Environmental Science and Policy 9: 509-524

Binning, C. Baker, B, Meharg, S, Cork. S, Kearns A. 2002. Making farm forestry pay: markets for ecosystem services - a scoping study to set future research. A report for the Rural Industries Research and Development Corporation. $74 \mathrm{p}$.

Brown, T.C., Peterson, G.L., Brodersen, R.M., Ford, V. and Bel, P.A. 2005. The judged seriousness of an environmental loss is a matter of what caused it. Journal of Environmental Psychology 25: 13-21

Calder, I. 2001. Forest valuation and water - the need to reconcile public and science perceptions', in Verweij, P., (ed), Understanding and Capturing the Multiple V alues of Tropical Forest. Tropenbos International, Netherlands.

Carney, D., 1999. Approaches to Sustainable Livelihoods for the Rural Poor. London: Overseas Development Institute.

Carpenter, S.R., DeFries, R., Dietz, T., Mooney, H.A., Polasky, S., Reid, W.V. and Scholes, R.J. 2006. Millennium Ecosystem Assessment: Research Needs. Science 314: 257-258.

Challen, R. 2000. Insititutions, Transaction Costs, and Environmental Policy: Institutional Reform for Water Resources. Edward Elgar. Cheltenham. UK.

Chomitz, K. M., and K. Kumari. 1998. The domestic benefits of tropical forests: a critical review, The World Bank Research Observer 13(1): 13-35.

Contreras-Hermosilla A and Fay CC. 2005. Strengthening forest management in Indonesia through land tenure reform: Issues and framework action. Washington, DC, USA. Forest Trends. $55 \mathrm{p}$.

Dennis R, Mayer J, Applegate G, Chokkalingam U, Colfer CJ, Kurniawan I, Lachowski H, Maus P, Permana RP, Ruchiat Y, Stolle F, Suyanto S and Tomich TP. 2005. Fire, people and pixels: Linking social science and remote sensing to understand underlying causes and impacts of fires in Indonesia. Human Ecology. 33(4):P. 465-503.

Dixon, J.A., Sherman, P. 1990. Economics of Protected Areas: a new look at benefits and costs. Washington D.C. Island Press.

Durst, P.B., C. Brown, H.D. Tacio, and M. Ishikawa (Eds.). 2005. In Search Of Excellence: Exemplary forest management in Asia and the Pacific. FAO, Bangkok. http://www.fao.org/documents/show_cdr.asp?url_file=/docrep/ 007/ ae542e/ae542e00.htm.

Emerton, L. and Bos, E. eds. 2004. VALUE - Counting ecosystems as water infrastructure. IUCN - the World Conservation Union, Gland (Switzerland). $88 \mathrm{pp}$

Farida, F., Jeanes, K., Kurniasari, D., Widayati, A., Ekadinata, A., Hadi, D.P., Joshi, L. Suyamto, D., van Noordwijk, M. 2005. Rapid Hydrological Appraisal (RHA) of Singkarak Lake in the context of Rewarding Upland Poor for Environmental Services. Draft of RUPES Working Paper. World Agroforestry Centre. http://www.worldagroforestrycentre.org/sea/networks/rupes/index.asp

Fay, C. and G. Michon. 2005. Redressing forestry hegemony: when a forestry regulatory framework is best replaced by an agrarian one. Forests, trees and Livelihoods 15: 193-209.

Ferraro, P., and A. Kiss. 2002. Direct payments to conserve biodiversity. Science 298:1718-1719.

Ferraro, P.J. and R.D. Simpson. 2005. Cost-Effective Conservation When Eco-entrepreneurs have Market

Power. Environment and Development Economics 10(5): 651-663.

Gaveau, D.L.A., Wandono, H. and Firman Setiabudidi, F. 2007. Three decades of deforestation in southwest Sumatra: Have protected areas halted forest loss and logging, and promoted re-growth? Biological Conservation 134: 495 -504

Griffin, R.C. 1991. The Welfare Analytics of Transaction Costs, Externalities and Institutional Choice. American Journal of Agricultural Economics. Vol. 73, No. 3 (Aug., 1991), pp. 601-614

Jeanes K, van Noordwijk M, Joshi L, Widayati A, Farida and Leimona B. 2006. Rapid Hydrological Appraisal in the context of environmental service rewards. Bogor, Indonesia. World Agroforestry Centre - ICRAF, SEA Regional Office. 56 p.

Johnson, N. White, A. and Perrot-Maître, D. 2001. Developing Markets for Water Services from Forests: Issues and Lessons for Innovators. Katoomba Group, World Resources Institute and Forest Trends, Washington DC 
Kaimowitz, D. 2000. Forestry assistance and tropical deforestation: why the public doesn't get what it pays for. International Forestry Review 2 (3):225-231.

Kleijn, D., Berendse, F., Smit, R. and Gilissen, N. 2001. Agri-environment schemes do not effectively protect biodiversity in Dutch agricultural landscapes. Nature 413: 723 - 725

Kuperan, K., Abdullah N.M.R., Pomeroy R.S., Genio, E.L. Salamanca, A.M. 1998. Measuring transaction costs of fisheries co-management. Paper presented at the $7^{\text {th }}$ Common Property Conference, Int. Assoc. for the Study of Common Property, Vancouver, B.C. Canada. 10-14 June

Kuncoro SA, van Noordwijk M and Martini, E., Saipothong, P., Areskoug, V., Ekadinata, A., and O'Connor, T., 2006. Rapid Agrobiodiversity Appraisal (RABA) in the context of environmental service rewards: protocols for data collection and case studies in rubber agroforest in Bungo district, Jambi, Indonesia and fragmented forest in north Thailand. Worldagroforestry Centre, ICRAF-Bogor (Indonesia) 106 pp. http://icrafnt2:88/Publications/currentpub.asp?publishid=1496

Landell-Mills, N. and Porras, I. 2001. Silver Bullet or Fools' Gold: A global review of markets for forest environmental services and their impact on the poor. International Institute for Environment and Development, London

Lee, D.R. and Barrett, C.B. (eds). 2001. Tradeoffs or Synergies? Agricultural Intensification, Economic Development and the Environment. CAB International, Wallingford, UK.

May, P.H., E. Boyd, F. Veiga and Chang, M. 2004. Local sustainable development effects of forest carbon projects in Brazil and Bolivia: a view from the field. International Institute for Environment and Development, London

Mburu J, Birner R and Zeller M. 2003. Relative Importance and Determinants of Landowners' Transaction Costs in Collaborative Wildlife Management in Kenya: An Empirical Analysis. Ecological Economics Vol. 45 (2003), pp: 59-73

McNeely J.A. and Scherr S.J. 2003. Ecoagriculture: Strategies to Feed the World and Save Wild Biodiversity. Island Press, Washington, DC.

Michon, G. 2005. Domesticating forests: How farmers manage forest resources. IRD, CIFOR, ICRAF.

Millennium Ecosystem Assessment, 2005. Ecosystems and Human Well-Being: Synthesis. Island Press, Washington, DC, (USA)

Miranda, M., I.T. Porras and M. L. Moreno. 2003. The social impacts of payments for environmental services in Costa Rica. A quantitative field survey and analysis of the Virilla watershed. International Institute for Environment and Development, London

Mulder, I. ten Kate, T. Scherr, S. 2006. Private Sector Demand in Markets for Ecosystem Services: Preliminary Findings. Adapted from full report submitted to the UNDP-GEF project: "Institutionalizing Payments for Ecosystem Services, supplement III. Mobilizing Private Sector Buyers for Ecosystem Services

Pattanayak, S. and R. Kramer. 2001. Pricing ecological services: Willingness to pay for drought mitigation from watershed protection in eastern Indonesia, Water Resources Research, 37(3): 771-778

Pyo, H. 2002. The Measurement of the Conservation V alue for Korean Wetlands Using the Contingent V aluation Method and Cost-Benefit Analysis. Korea Maritime Institute, Seoul

Rees, W.E. 1992. Ecological footprints and appropriated carrying capacity: what urban economics leaves out. Environment \& Urbanization 4: 121-130

Rees, W.E. 2002. An ecological economics perspective on sustainability and prospects for ending poverty. Population and Environment 24: 15-46

Reid, W.V. 2001. Capturing the value of ecosystem services to protect biodiversity. In Chichilenisky, G., Daily, G.C., Ehrlich, P., Heal, G., and J.S. Miller, Managing Human-Dominated Ecosystems, Missouri Botanical Garden Press, St Louis.

Rojas, M. and Aylward, B. 2003. What are we learning from experiences with markets for environmental services in Costa Rica? A review and critique of the literature. International Institute for Environment and Development, London.

Sachs, J.D. 2005. The End of Poverty: How We Can Make it Happen in our Life Time. Penguin Books, London (UK).

Schwank, O. 2004. Concerns about CDM projects based on decomposition of HFC-23 emissions from 22 HCFC production sites. http://cdm.unfccc.int/public_inputs/ inputam0001/Comment_AM0001_Schwank_081004.pdf

Suyanto S, Permana RP, Khususiyah N and Joshi L. 2004. Land tenure agroforestry adoption and reduction of fire hazard in a forest: a case study from Lampung, Sumatra Indonesia. Agroforestry Systems. 65(1):P. 1-11

Suyanto, S. Khususiyah, N. Purnomosidhi, P. Jonson, E. Rasna, R. Suryadi, C. 2006. Conditional Land Tenure: A pathway to healthy landscapes and enhance livelihoods. RUPES Sumberjaya Brief No.1. World Agroforestry Centre http://www.worldagroforestrycentre.org/sea/networks/rupes/index.asp

Suyanto, S. Widodo, R.H., Purnomosidhi, P. Susanto, S. Verbist, B. 2006. Clean rivers, lighted lights: monetary rewards for reducing sediment. RUPES Sumberjaya Brief No.2. World Agroforestry Centre. http://www.worldagroforestrycentre.org/sea/networks/rupes/index.asp 
Tognetti, S., Mendoza, G., Southgate, D., Aylward, B. and L. Garcia. 2003. Assessing the effectiveness of payment arrangements for watershed ecosystem services (PWES)', paper presented at Third Latin American Congress on Watershed Management,

Tomich, T.P. Kuusipalo, J., Menz, K. and Byron, N. 1996. Imperata economics and policy. Agroforestry Systems 36: 233-261..

Tomich, T.P., Kenneth Chomitz, K. Francisco, H., Izac, A.M., Murdiyarso,D., Ratner, B., Thomas, D.E. and Van Noordwijk. M. 2004a. Asking the right questions: Policy analysis and environmental problems at different scales. Agriculture, Ecosystems and Environment, 104: 5-18

Tomich T.P., D.E. Thomas, and M. van Noordwijk. 2004p. Environmental services and land use change in Southeast Asia: from recognition to regulation or reward? Agriculture, Ecosystems and Environment 104: 229-244._http:// www.asb.cgiar. org/pdfwebdocs/AGEE_special_4.S_Tomich.pdf.

Tomich T.P., A. Cattaneo, S. Chater, H.J. Geist, J. Gockowski J., D. Kaimowitz, E.F. Lambin, J. Lewis, O. Ndoye, C.A. Palm, F. Stolle, W.D. Sunderlin, J.F. Valentim, M. van Noordwijk, and S.A. Vosti. 2005. Balancing agricultural development and environmental objectives: assessing tradeoffs in the humid tropics. In Palm C.A., Vosti S.A., Sanchez P.A. and Ericksen P.J. (eds) Slash and Burn: The Search for Alternatives. New York: Columbia University Press.

van Noordwijk, M., J. Poulsen, and P. Ericksen. 2004a. Filters, flows and fallacies: Quantifying off-site effects of land use change. Agriculture, Ecosystems and Environment, 104: 19-34.

van Noordwijk, M., F.J.C. Chandler, and T.P. Tomich. 2004b. An Introduction to the Conceptual Basis of RUPES. RUPES working paper. http:// www. worldagroforestry.org/ sea/ Networks/RUPES/ wpapers.htm.

van Noordwijk, M. 2005. RUPES typology of environmental service worthy of reward. RUPES working paper, ICRAF-Southeast Asia, Bogor. 53 pp.

van Noordwijk, M., A. Widayati, B. Lusiana, K. Hairiah, B. Arifin. 2005. What Can a Clean Development Mechanism Do to Enhance Trees in the Landscape? Experience with Rubber, Coffee and Timberbased Agroforestry Systems in Indonesia. In: Murdiyarso, D. and Herawati, H. (eds.) 2005. Carbon forestry: who will benefit? Proceedings of Workshop on Carbon Sequestration and Sustainable Liveliboods. Bogor, Indonesia, CIFOR. 215p. ISBN: 979-3361-73-5. pp 92-111 http://www.cifor.cgiar. org/publications/ pdf_files/Books/ BMurdiyarso0501.pdf.

Waage, S. Scherr, S. Jenkins, M, Inbar, M. 2006. A scoping assessment of current work on payments for ecosystem services in Asia, Latin America and East \& Southern Africa. A research summary adapted from the full report submitted to the UNDP-GEF project: "Institutionalizing Payments for Ecosystem Services, supplement III. Building National Capacity for PES.

Wunder, S. 2005. Payments for environmental services: Some nuts and bolts. CIFOR Occasional Paper. No. 42. 24p. http://www.cifor.org/ publications/pdf_files/ OccPapers/OP-42.pdf.

Wunder, S. 2006. Are direct payments for environmental services spelling doom for sustainable forest management in the tropics? Ecology and Society 11(2): 23. [online] URL:

Wunscher, T., Engel, S., Wunder, S. 2006. Payments for environmental services in Costa Rica: increasing efficiency through spatial differentiation. Quarterly Journal of International Agriculture 45(4): 317335.http://www.ecologyandsociety.org/vol11/iss2/art23/

Zhang, Y. and Li, Y. 2005. Valuing or pricing natural and environmental resources? Environmental Science \& Policy 8: 179-186. 


\section{ICRAF Working Papers}

2005-2006

1. Agroforestry in the drylands of eastern Africa: a call to action

2. Biodiversity conservation through agroforestry: managing tree species diversity within a network of community-based, nongovernmental, governmental and research organizations in western Kenya.

3. Invasion of prosopis juliflora and local livelihoods: Case study from the Lake Baringo area of Kenya

4. Leadership for change in Farmers Organizations: Training report: Ridar Hotel, Kampala, 29th March to 2nd April 2005

5. Domestication des espèces agroforestières au Sahel : situation actuelle et perspectives

6. Relevé des données de biodiversité ligneuse: Manuel du projet biodiversité des parcs agroforestiers au Sahel

7. Improved Land Management in the Lake Victoria Basin: TransVic Project's Draft Report

8. Livelihood capital, strategies and outcomes in the Taita hills of Kenya

9. Les espèces ligneuses et leurs usages: Les préférences des paysans dans le Cercle de Ségou, au Mali

10. La biodiversité des espèces ligneuses: Diversité arborée et unités de gestion du terroir dans le Cercle de Ségou, au Mali

11. Bird diversity and land use on the slopes of Mt. Kilimanjaro and the adjacent plains, Tanzania

12. Water, women and local social organization in the Western Kenya Highlands

13. Highlights of ongoing research of the World Agroforestry Centre in Indonesia

14. Prospects of adoption of tree-based systems in a rural landscape and its likely impacts on carbon stocks and farmers' welfare: the FALLOW Model Application in Muara Sungkai, Lampung, Sumatra, in a 'Clean Development Mechanism' context

15. Equipping Integrated Natural Resource Managers for Healthy Agroforestry Landscapes.

16. Are they competing or compensating on farm? Status of indigenous and exotic tree species in a wide range of agro-ecological zones of Eastern and Central Kenya, surrounding Mt. Kenya.

17. Agro-biodiversity and CGIAR tree and forest science: approaches and examples from Sumatra

18. Improving land management in eastern and southern Africa: A review of polices.

19. Farm and Household Economic Study of Kecamatan Nanggung, Kabupaten Bogor, Indonesia: A Socio-economic base line study of Agroforestry Innovations and Livelihood Enhancement

20. Lessons from eastern Africa's unsustainable charcoal business.

21. Evolution of RELMA's approaches to land management: Lessons from two decades of research and development in eastern and southern Africa

22. Participatory watershed management: Lessons from RELMA's work with farmers in eastern Africa.

23. Strengthening farmers' organizations: The experience of RELMA and ULAMP.

24. Promoting rainwater harvesting in eastern and southern Africa.

25. The role of livestock in integrated land management.

26. Status of carbon sequestration projects in Africa: Potential benefits and challenges to scaling up. 
27. Social and Environmental Trade-Offs in Tree Species Selection: A Methodology for Identifying Niche Incompatibilities in Agroforestry [Appears as AHI Working Paper no. 9]

28. Managing Trade-Offs in Agroforestry: From Conflict to Collaboration in Natural Resource Management. [Appears as AHI Working Paper no. 10]

29. Essai d'analyse de la prise en compte des systemes agroforestiers pa les legislations forestieres au Sahel: Cas du Burkina Faso, du Mali, du Niger et du Senegal.

30. Etat de la Recherche Agroforestière au Rwanda Etude bibliographique, période 1987-2003.

31. Science and Technological Innovations for Improving Soil fertility and Management in Africa.

32. Compensation and Rewards for Environmental Services in the Developing World: Framing Pan-Tropical Analysis and Comparison.

33. Report on the Latin American Regional Workshop on Compensation for Environmental Services and Poverty Alleviation in Latin America.

34. Asia Regional Workshop on Compensation for Ecosystems Services. A component of the global scoping study on compensation for ecosystem services.

35. African Regional Workshop on Compensation for Ecosystem Services (CES)

36. Exploring the inter-linkages among and between Compensation and Rewards for Ecosystem Services (CRES) and human well-being: CES Scoping Study Issue Paper no. 1.

37. Criteria and indicators for environmental service compensation and reward mechanisms: realistic, voluntary, conditional and pro-poor: CES Scoping Study Issue Paper no. 2.

38. The conditions for effective mechanisms of Compensation and Rewards for Environmental Services (CRES): CES Scoping Study Issue Paper no. 3.

39. Organization and governance for fostering pro-poor Compensation for Environmental Services: CES Scoping Study Issue Paper no. 4.

40. How important will different types of Compensation and Reward Mechanisms be in shaping poverty \& ecosystem services across Africa, Asia \& Latin America over the next two decades? CES Scoping Study Issue Paper no. 5. 


\section{Who we are}

The World Agroforestry Centre is the international leader in the science and practice of integrating 'working trees' on small farms and in rural landscapes. We have invigorated the ancient practice of growing trees on farms, using innovative science for development to transform lives and landscapes.

\section{Our vision}

Our Vision is an 'Agroforestry Transformation' in the developing world resulting in a massive increase in the use of working trees on working landscapes by smallholder rural households that helps ensure security in food, nutrition, income, health, shelter and energy and a regenerated environment.

\section{Our mission}

Our mission is to advance the science and practice of agroforestry to help realize an 'Agroforestry Transformation' throughout the developing world.
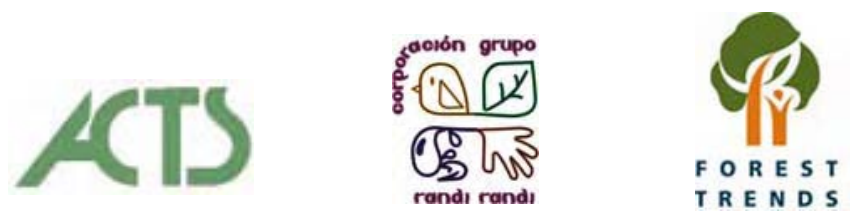

The World Conservation Union
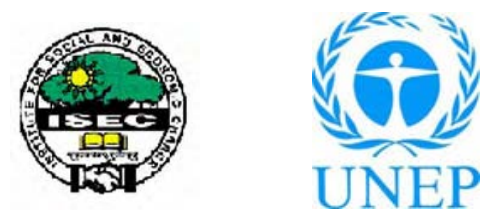

\section{IDRC * CRDI}

International Development

Centre de rechenches pour le

Research Centue

developpenert interations

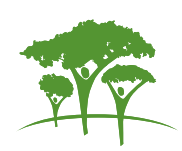

United Nations Avenue, Gigiri - PO Box 30677 - 00100 Nairobi, Kenya

Tel: +254207224000 or via USA +16508336645

Fax: +254207224001 or via USA +1 6508336646

www.worldagroforestry.org 